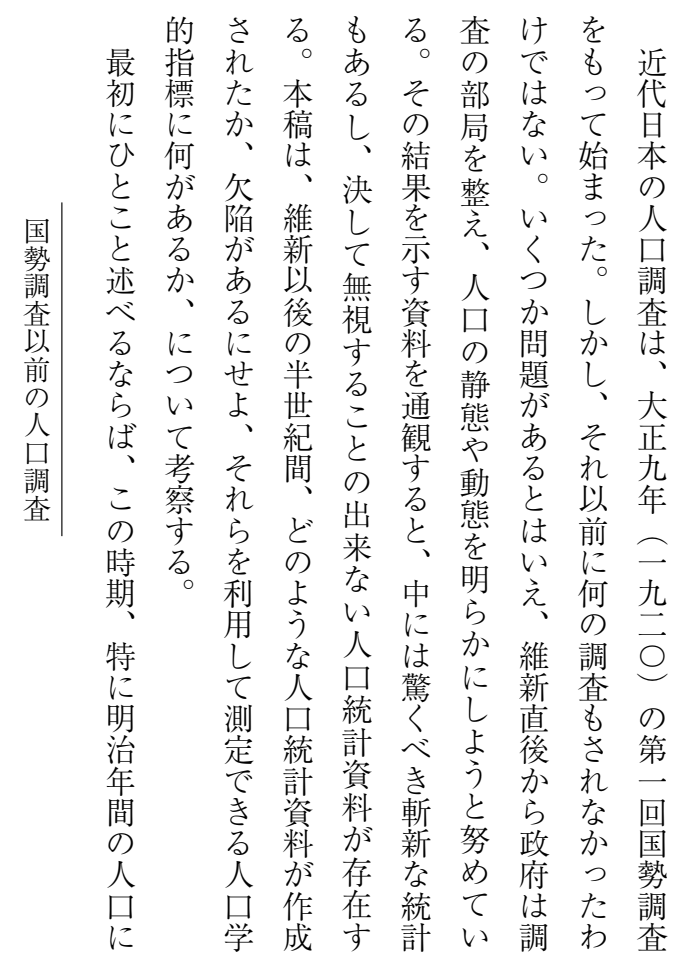

は
し
に

国

勢

調

查

以

前

の

人

口

調

査

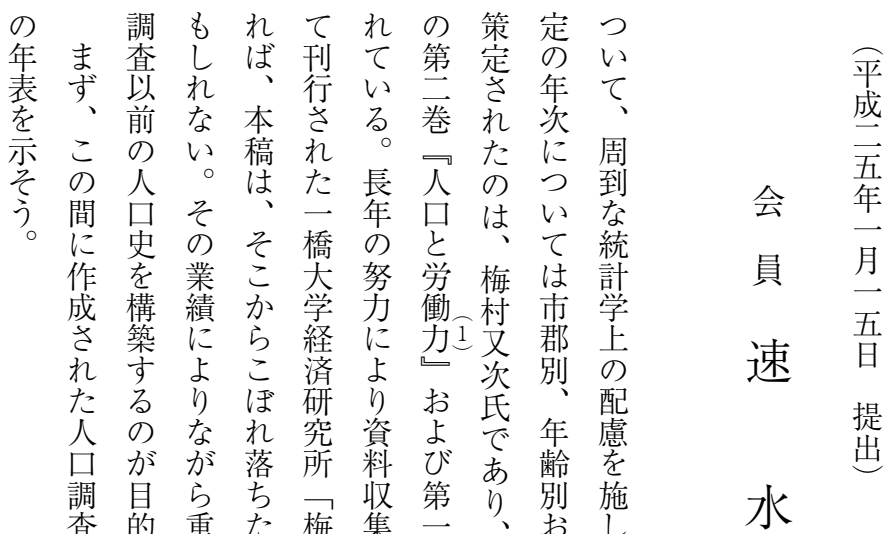

資 で複枝村

おる避を計料結職ら

ぶ。け取声の地果業、

関よ扱房味域は経版

連り豪の済長人別

事充に偉統統長口

項実過業計計経を府旧

によきにな妈に緕府国

い 勢か 心 経さ示計別特

融 
維新（1868）以降第 1 回国勢調査（1920）に至る間の人口統計資料年表

\begin{tabular}{|c|c|c|c|}
\hline $\begin{array}{l}\text { 明治元年 } \\
\text { 明治 } 2 \text { 年 } \\
\text { 明治 } 3 \text { 年 }\end{array}$ & $\begin{array}{l}1868 \\
1869 \\
1870\end{array}$ & & $\begin{array}{l}\text { 京都府戸籍仕法書 } \\
\text { 駿河沼津政表‧原政表 } \\
\text { 庚午戸籍 }\end{array}$ \\
\hline $\begin{array}{l}\text { 明治 } 4 \text { 年 } \\
\text { 明治 } 5 \text { 年 } \\
\text { 明治 } 6 \text { 年 } \\
\text { 明治 } 7 \text { 年 } \\
\text { 明治 } 8 \text { 年 }\end{array}$ & $\begin{array}{l}1871 \\
1872 \\
1873 \\
1874 \\
1875\end{array}$ & $\begin{array}{l}\text { 日本全国戸籍表 } \\
\text { 日本全国戸籍表 } \\
\text { 日本全国戸籍表 } \\
\text { 日本全国戸籍表 }\end{array}$ & $\begin{array}{l}\text { 廃藩置県 } \\
\text { 壬申戸籍編製・琉球藩設置 } \\
\text { 徵兵令施行 } \\
\text { 樺太·千島交換条約 } \\
\text { 共武政表（第 } 1 \text { 回） }\end{array}$ \\
\hline $\begin{array}{l}\text { 明治 } 9 \text { 年 } \\
\text { 明治 } 10 \text { 年 } \\
\text { 明治11年 } \\
\text { 明治 } 12 \text { 年 } \\
\text { 明治 } 13 \text { 年 }\end{array}$ & $\begin{array}{l}1876 \\
1877 \\
1878 \\
1879 \\
\\
1880\end{array}$ & $\begin{array}{l}\text { 日本全国戸籍表 } \\
\text { 日本全国戸口表 } \\
\text { 日本全国戸口表 } \\
\text { 日本全国郡区分人口表 } \\
\\
\text { 日本全国人口表 }\end{array}$ & $\begin{array}{l}\text { 司法省民事慣例類集（1880も） } \\
\text { 沖縄県設置 } \\
\text { 杉：甲斐国現在人別調査実施 } \\
\text { 杉、東京学士会院会員 }\end{array}$ \\
\hline $\begin{array}{l}\text { 明治14年 } \\
\text { 明治15年 } \\
\text { 明治16年 } \\
\text { 明治17年 } \\
\text { 明治18年 }\end{array}$ & $\begin{array}{l}1881 \\
1882 \\
1883 \\
1884 \\
1885\end{array}$ & \begin{tabular}{|l} 
日本全国人口表 \\
日本全国戸口表 \\
日本全国民籍戸口表 \\
日本帝国民籍戸口表 \\
日本帝国民籍戸口表
\end{tabular} & $\begin{array}{l}\text { 松方デフレ、統計院設置 } \\
\text { 統計年鑑（第 } 1 \text { 回） } \\
\text { 徵発物件一覧表, 共立統計学校 } \\
\text { 都府名邑戸口表 } \\
\text { 統計院 } \rightarrow 内 \text { 閣統計局, 内閣制度成立 } \\
\text { 共立統計学校廃校 }\end{array}$ \\
\hline $\begin{array}{l}\text { 明治19年 } \\
\text { 明治 } 20 \text { 年 } \\
\text { 明治 } 21 \text { 年 } \\
\text { 明治 } 22 \text { 年 } \\
\text { 明治 } 23 \text { 年 }\end{array}$ & $\begin{array}{l}1886 \\
1887 \\
1888 \\
1889 \\
1890\end{array}$ & $\begin{array}{l}\text { 日本帝国民籍戸口表 } \\
\text { 日本帝国民籍戸口表 } \\
\text { 日本帝国民籍戸口表 } \\
\text { 日本帝国民籍戸口表 } \\
\text { 日本帝国民籍戸口表 }\end{array}$ & $\begin{array}{l}\text { 神奈川県統計書(「現住者産婦」) } \\
\text { 市町村制成立，藤澤氏生命表 } \\
\text { 憲法公布 } \\
\text { 議会制度成立 }\end{array}$ \\
\hline $\begin{array}{l}\text { 明治 } 24 \text { 年 } \\
\text { 明治 } 25 \text { 年 } \\
\text { 明治 } 26 \text { 年 } \\
\text { 明治 } 27 \text { 年 } \\
\text { 明治 } 28 \text { 年 }\end{array}$ & $\begin{array}{l}1891 \\
1892 \\
1893 \\
1894 \\
1895\end{array}$ & $\begin{array}{l}\text { 日本帝国民籍戸口表 } \\
\text { 日本帝国民籍戸口表 } \\
\text { 日本帝国民籍戸口表 } \\
\text { 日本帝国民籍戸口表 } \\
\text { 日本帝国民籍戸口表 }\end{array}$ & $\begin{array}{l}\text { 統計局 } \rightarrow \text { 統計課 } \\
\text { 日清戦争 }(-95) \\
\text { 1900年に国勢調査施行を惩汿さる }\end{array}$ \\
\hline
\end{tabular}




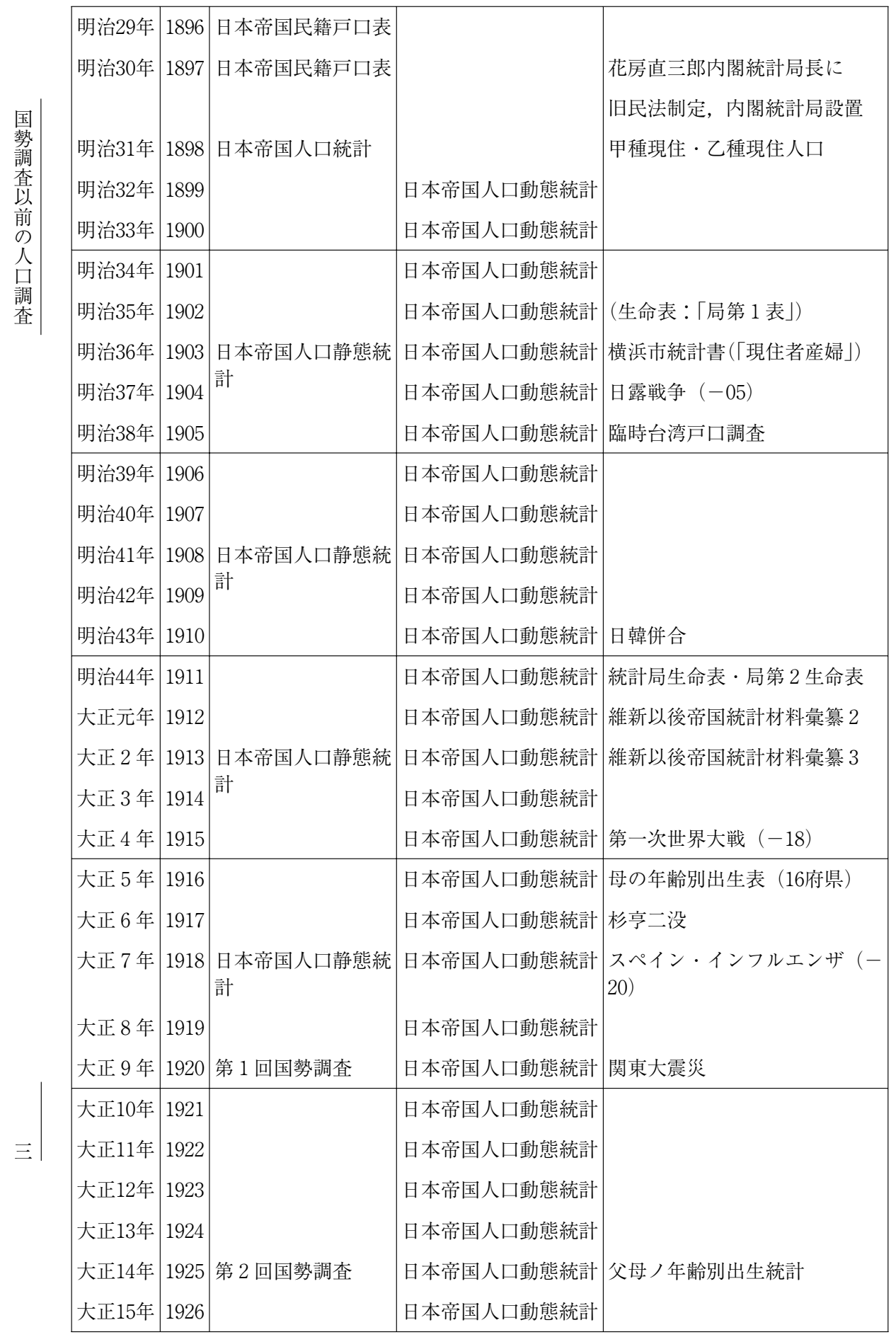




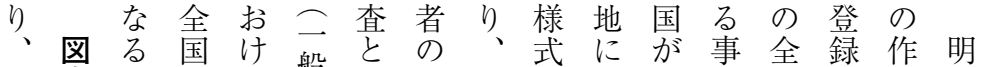

こ表。人る般は処幼・統を住し成治

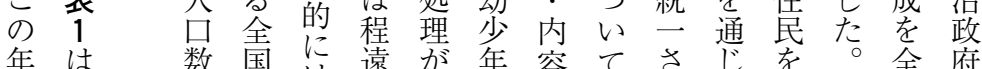

に 年 は 数国は遠が年容て さ

に始明人型武結定柃

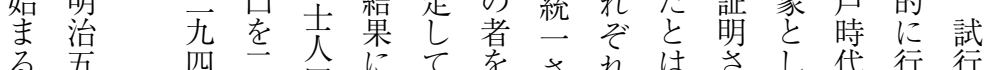

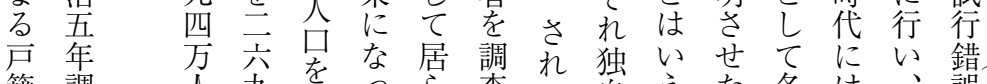

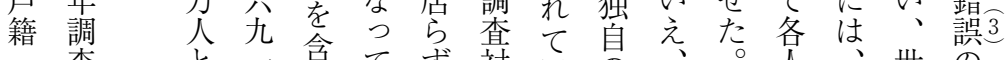

玍査学无

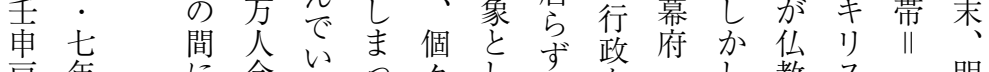

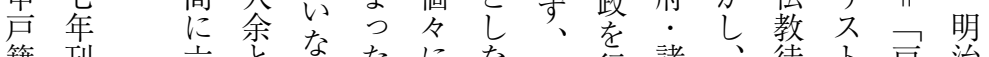

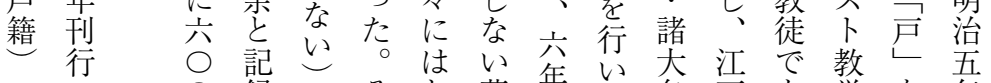

のの録はそと翻年い名立あ㛜を年

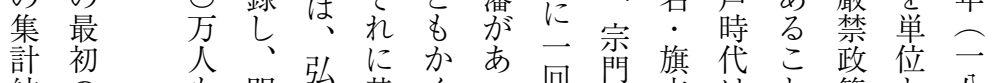

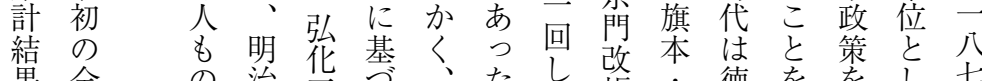

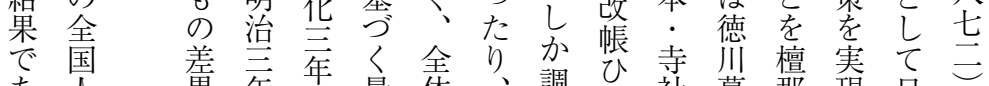

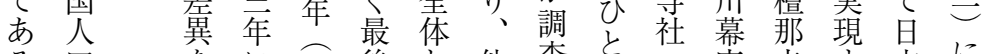

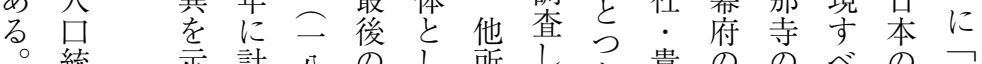

明梳示計八 の し 所 し 算四国て

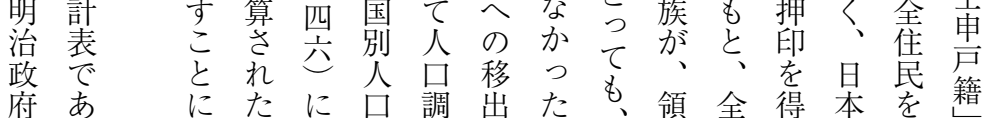

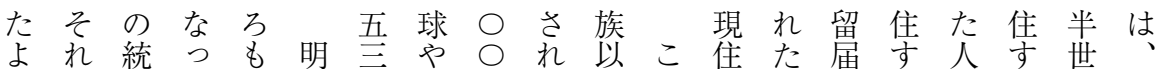

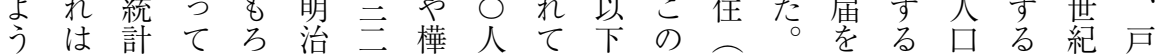

に他と行の-年太とい平図まそ提場が場近籍

の 組く統○との訂る 民表たし 出合本所くを

明機み 時計年い人正がににはていに籍字こ人

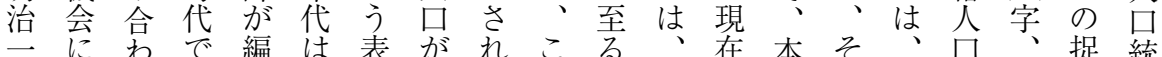

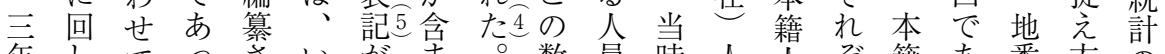

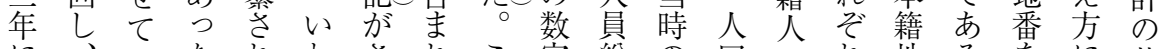

に、みたれわされる字総の口机扡るをに基

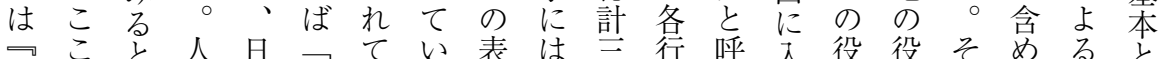

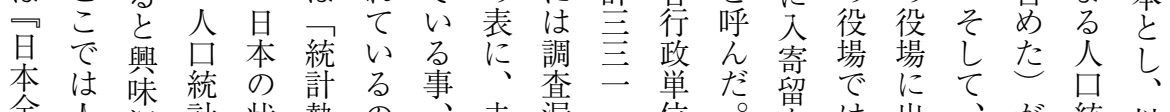

全人 深計状熱の素未漏一位。留は出、が統以

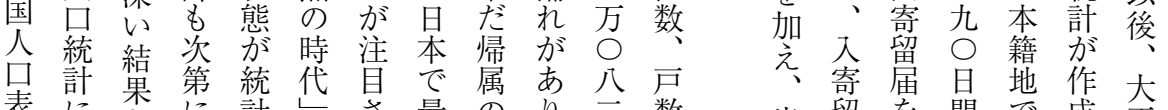

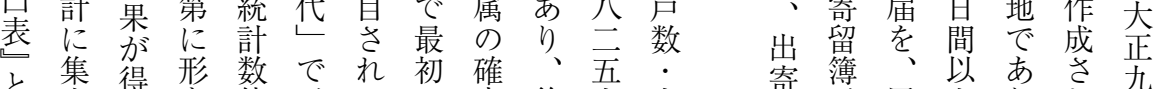

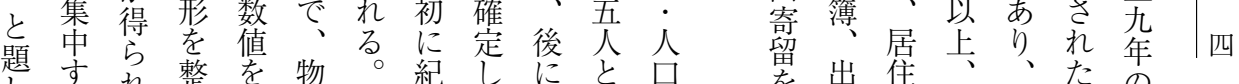

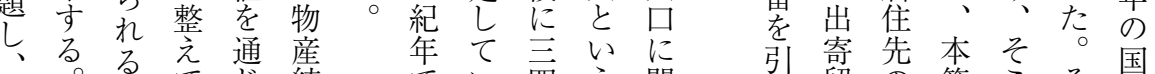

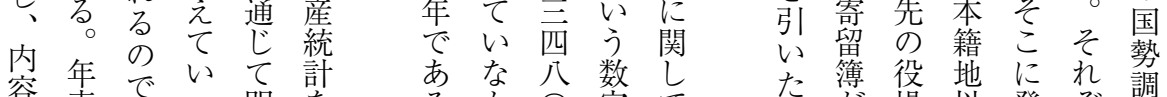

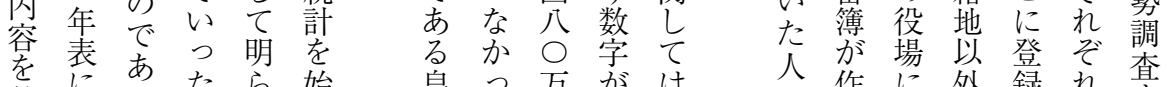

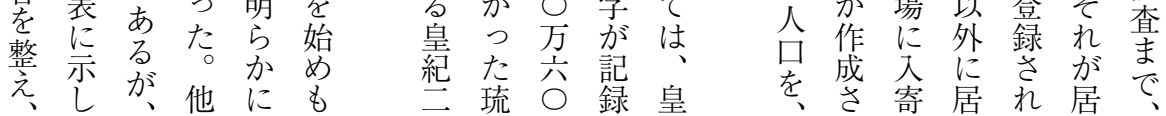




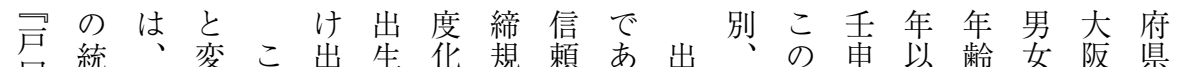

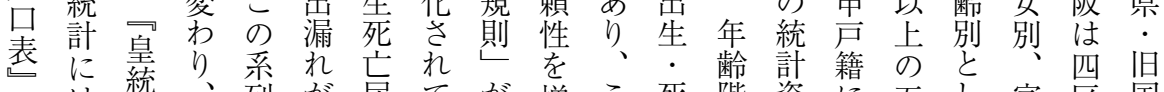

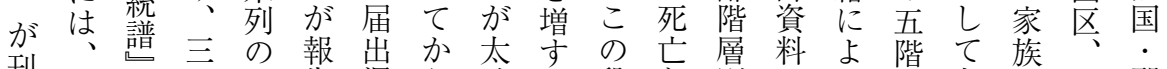
国行重に $\overrightarrow{0}$ 資告漏ら政の段と別にう層七七。京郡 勢 さ 要 移

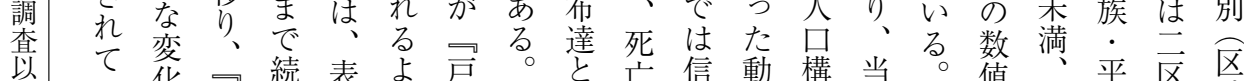
前 心化 号続 表 よ 戸

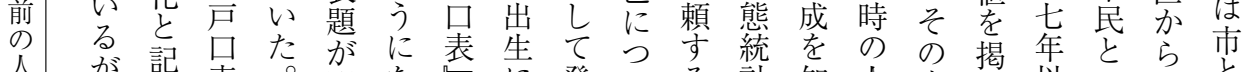

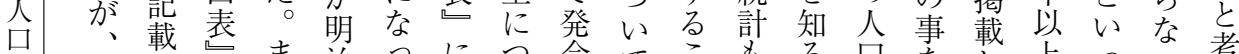

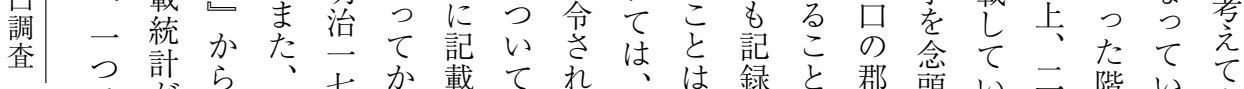

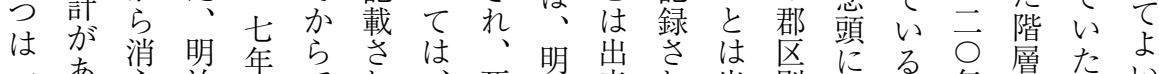

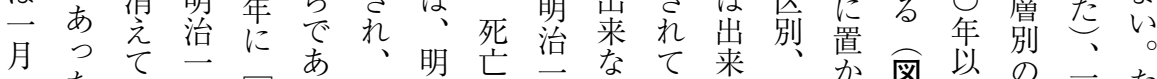

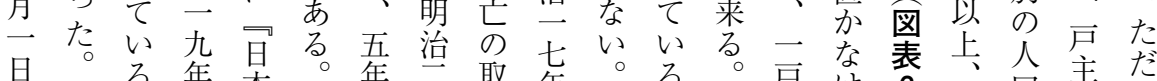
時こる。年本。年二 取年出 けのこ降国蒂遡年扱墓橉い もに 明皇籍 て 降 が地数ず別京

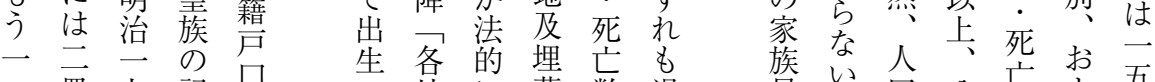

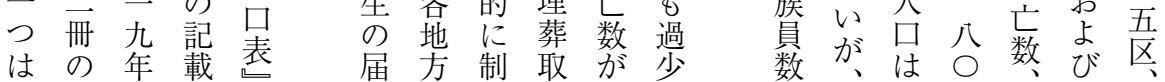

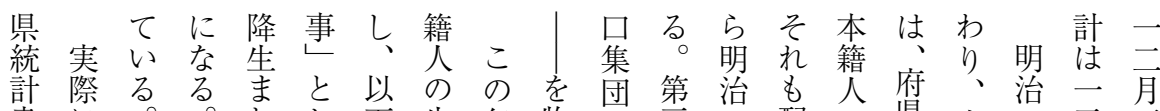

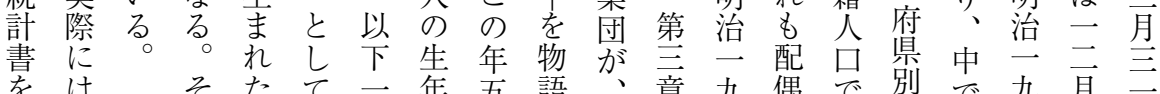

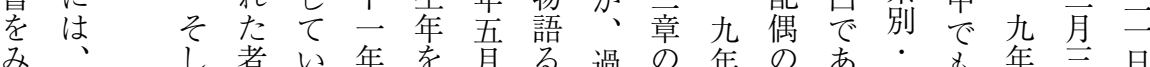

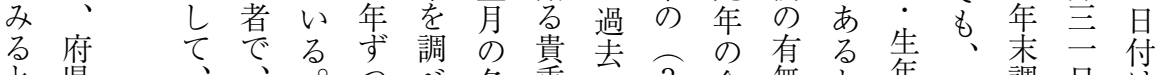
と県 同一 神間様二生遡 る 府な経で国別は統い・第の 付で

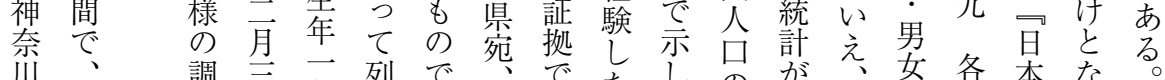

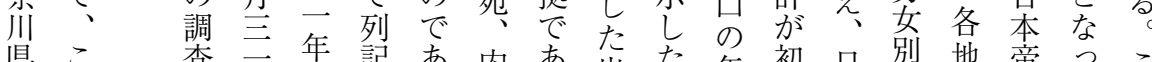
県こ査二年記あ内あ出た年初日別地帝つこ

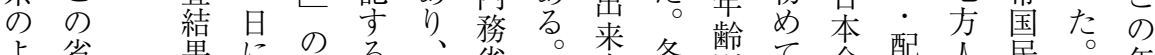

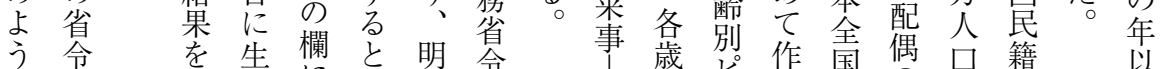
に采受六存に 毎取 ごて

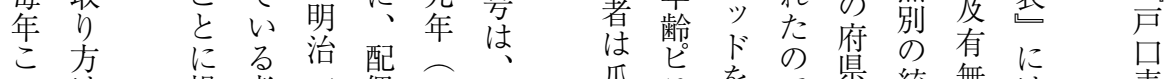

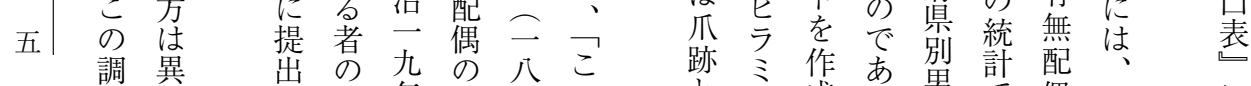

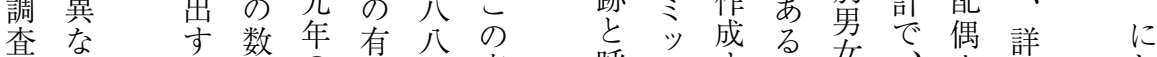

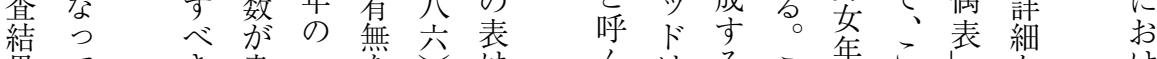

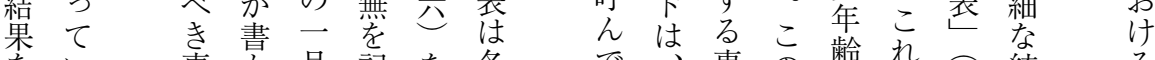

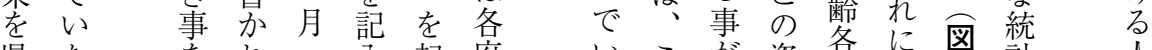

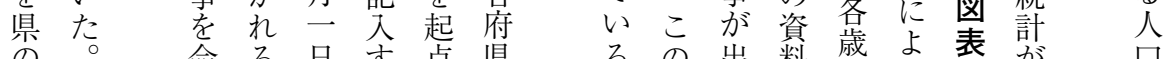
統 府 等事 以 る 


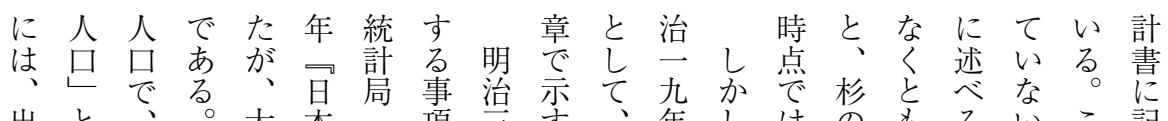
出としこし 部帝 初 留てれ分国代司年に常いこの立でう杉調し

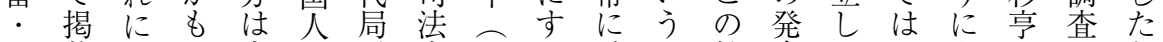

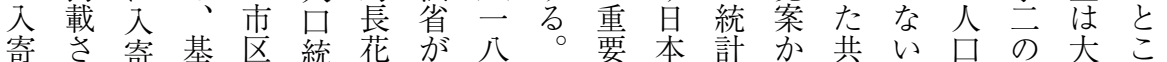

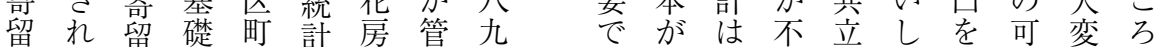
のて思と村嵒直掌八公まい明統、配能有も

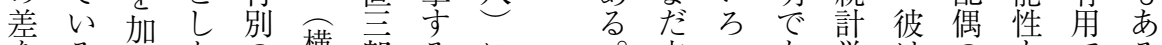
をる。考た の 横 郎るるに

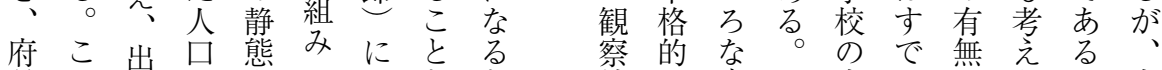

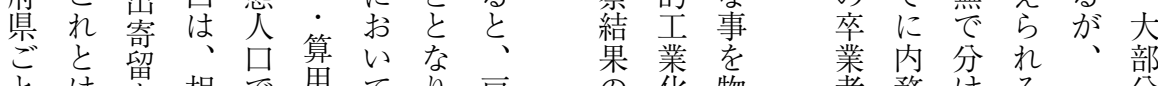

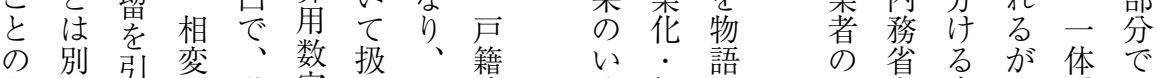

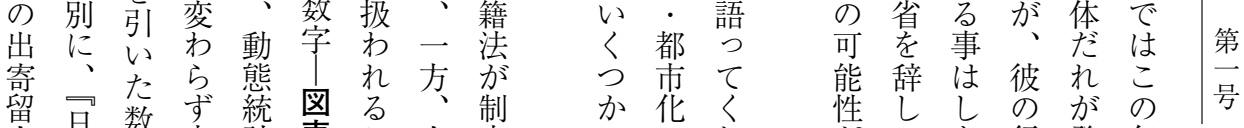

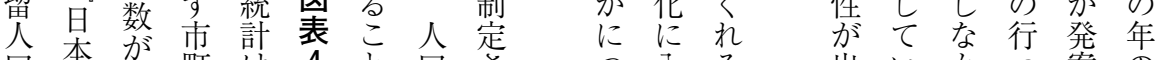

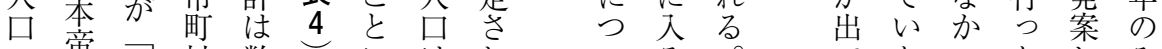

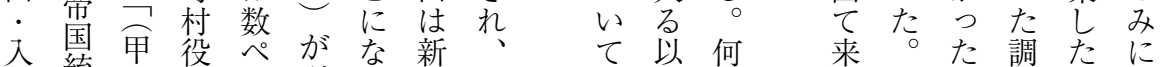

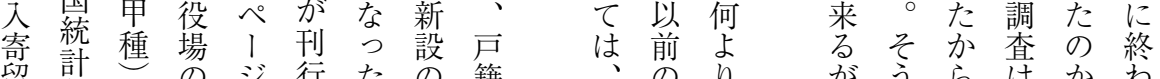
留年 誢 本 の さ 口鑑住籍 み れ 同閣 関 第記 録明 現る 少後 つ て

調統いれ県る受牙歳てに韭は国こ住の口の

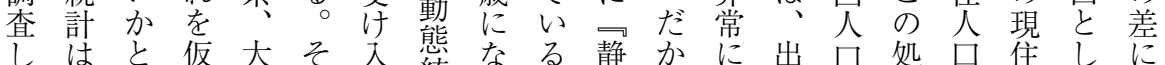
な不考説分れ れ統なっ。態ら 詳生動理 二集て按

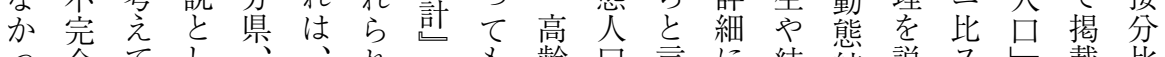
全てしでも齢口言に結統説ス 載比 たないて山西なで方者いつな婚計明レでし例 可 の る

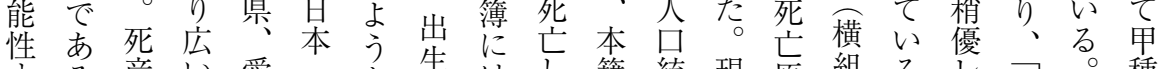

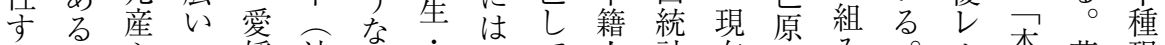

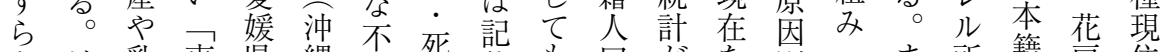

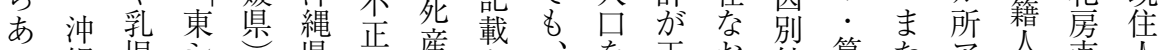

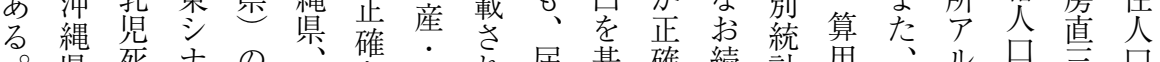
そ目死 ナ の $匚$ 海 統 鹿 数 死 て 出 礎 に

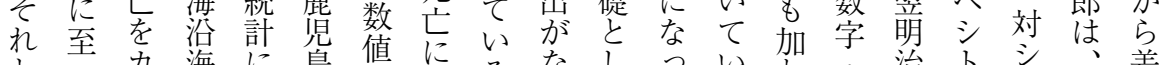

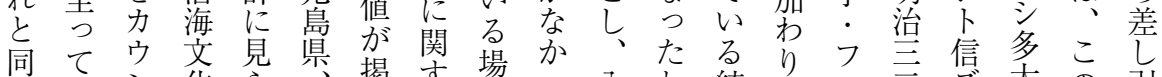
時はン化ら揭卞場つ入わ統、、ラ三售大の引 に、卜圈れ熊載る合た寄け計府ン年と艺洞己き

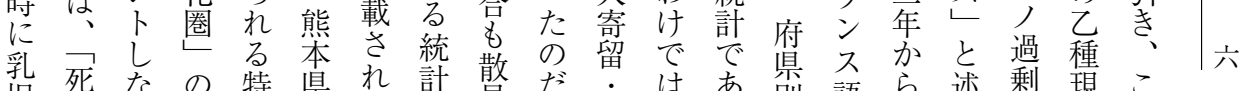
临痤な

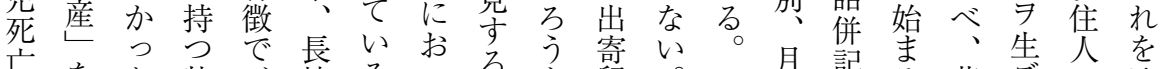

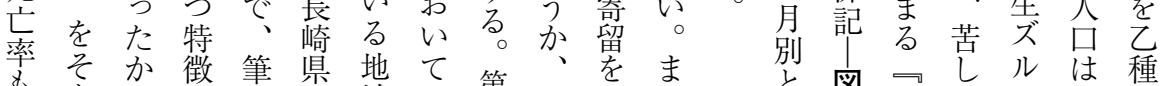

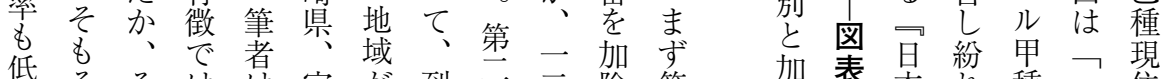

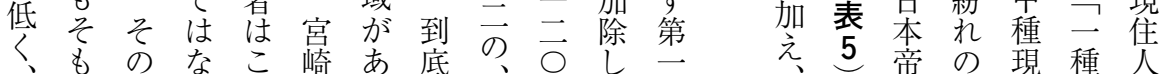




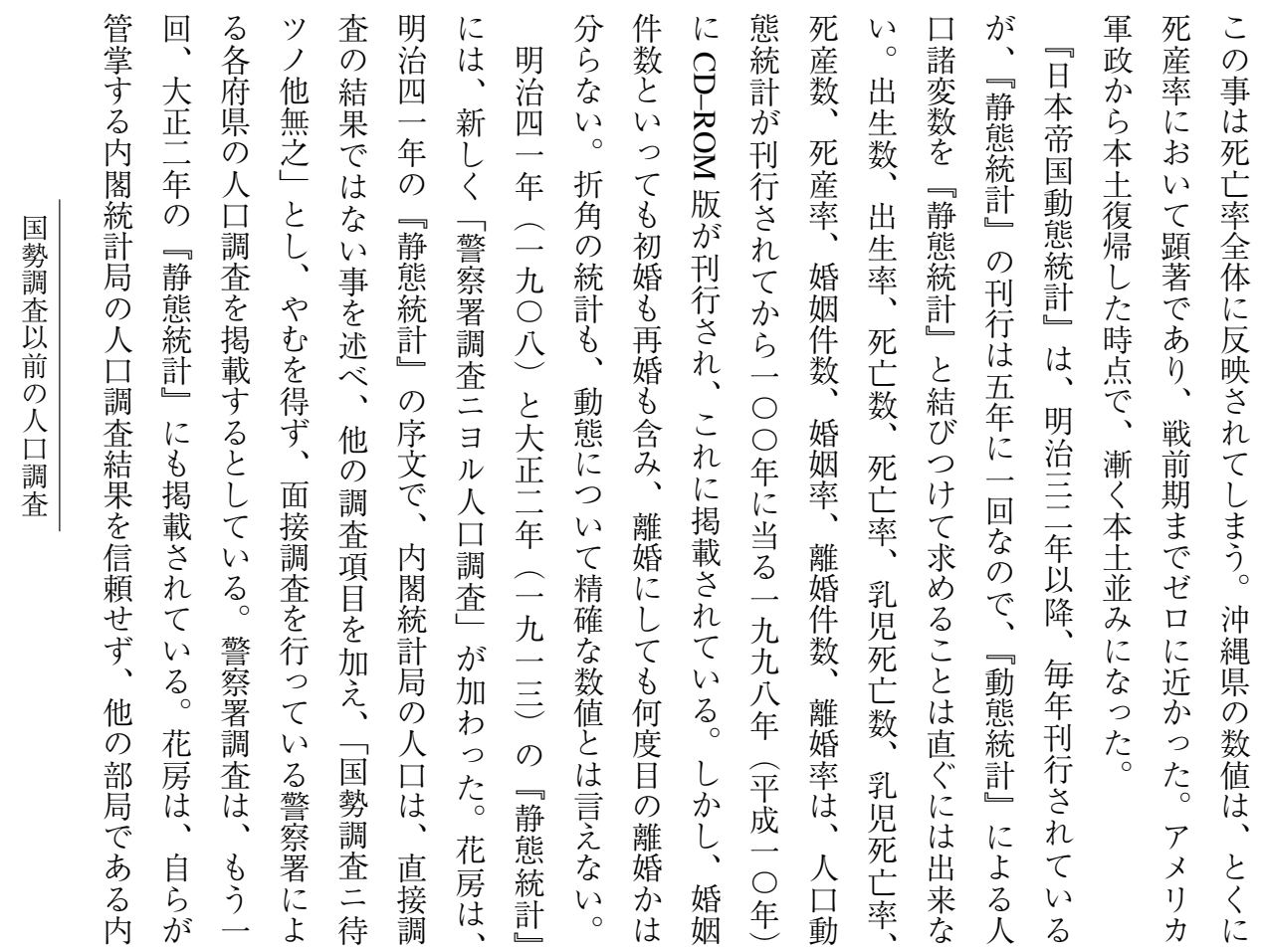

留の独部年

の人自にの次

必口のよロに

要 が調つ共年

か 記 查て 武表

記さは纂表右

録れな岂側

さまくれた䄈

てまさた六挙

心水戸種年た

る車表の地々

荷或地㛎く

車 数 統 の

車字梳徵 資

学をで発料

校用あ物至

寺て が覧 事

等る人表に

数たにはる

軍、参 明

隊都て謀治

駐市は本八

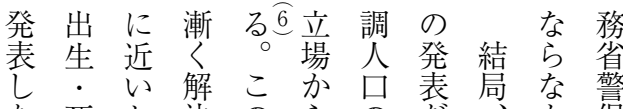

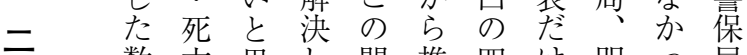

二 数亡 思占問推四注明つ局

そ值の゙わた題計種で治た の

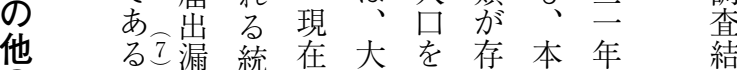

の 扎計正発在籍以以果

人をは国杂表守人降想

口
統
計
凟
料

す、勢年しる口

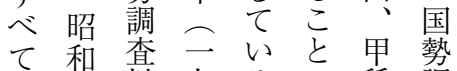

考五以九るに種調

慮年 前二のな 現 查計

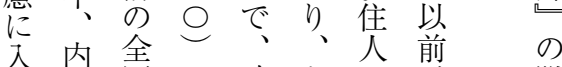

れ閣国の確ささ口

、統人第定ら、日 録

推計局に回な的に研種の 本 と

計忽つ国数究現人积

と行い勢值者住只掏利

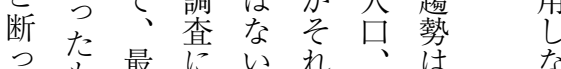

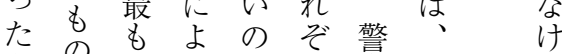

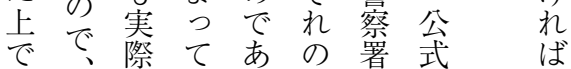




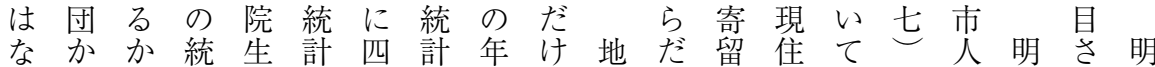

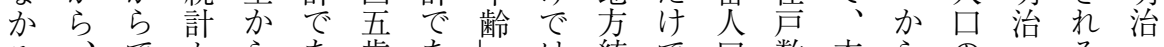
ろ、でから あ 歳 あしは 統で口数本ら、の二 る

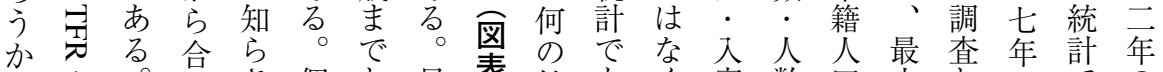

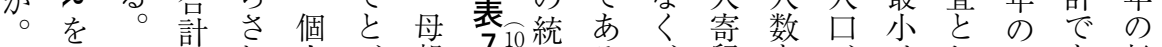

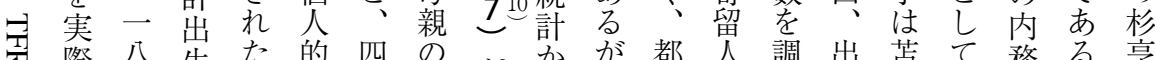

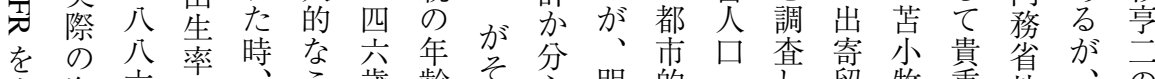
求資六

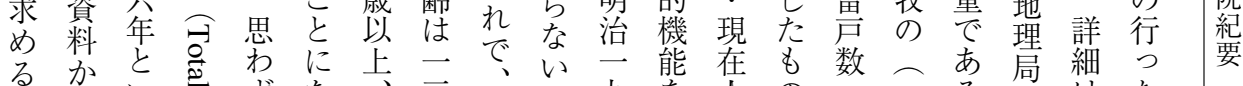

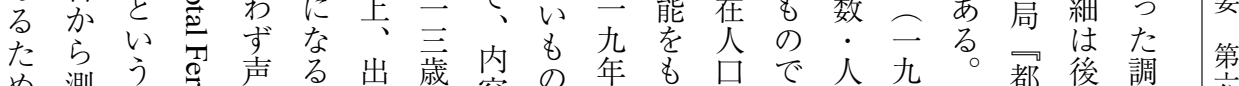
ゆ 测定 早

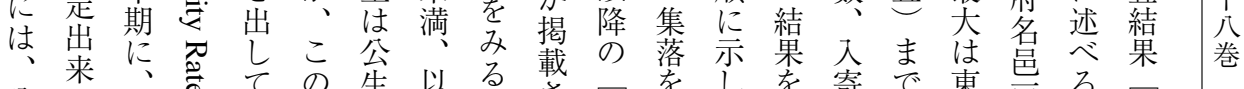

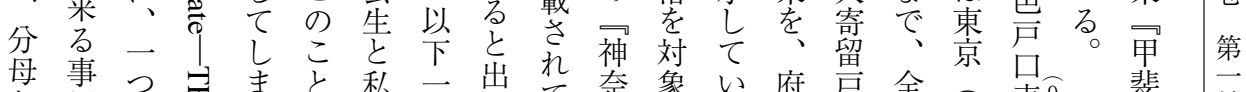
其事つ

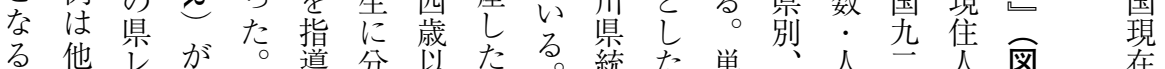

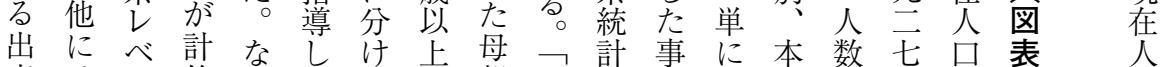

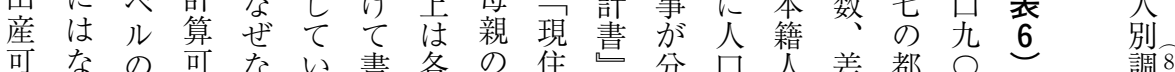

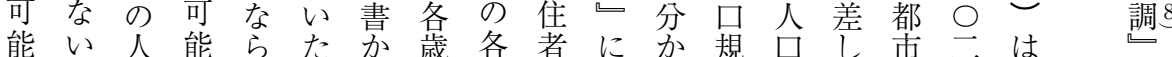

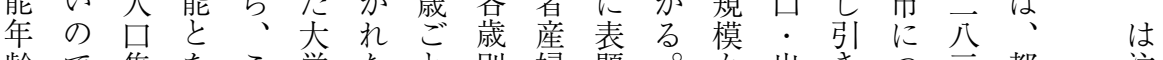
齢で集なこ学たと別婦題。出きうき都注

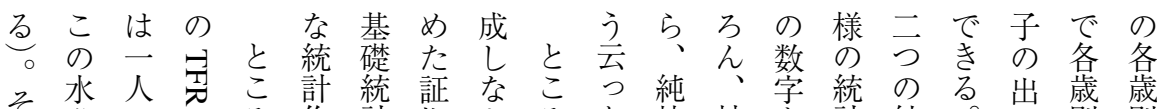

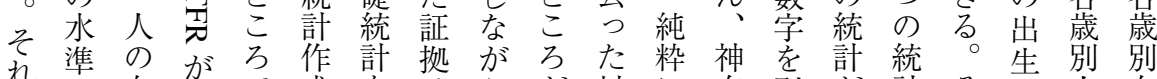
でが女用で成をはら、対に奈引仿計そ率人爻 は続性い珇の作な、比都川け揭ををし が口手 誰 限生 れ 在示 がり、涯てでをた結か川能農は神れて神莽計を の 日 産るい先 る こ

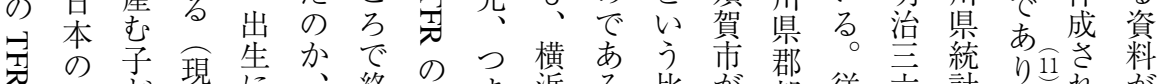

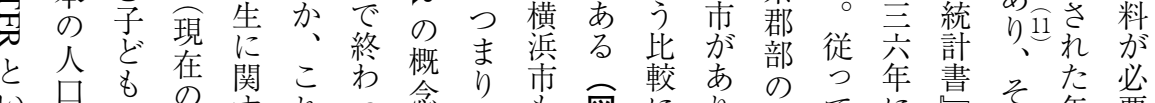
うは の

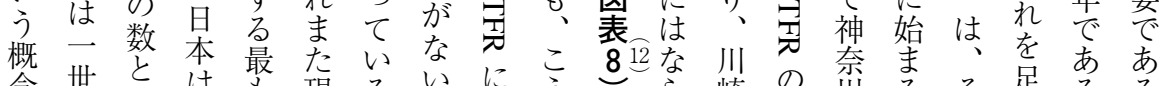
念 世代見は聚現る い相う

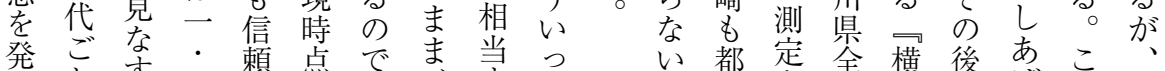

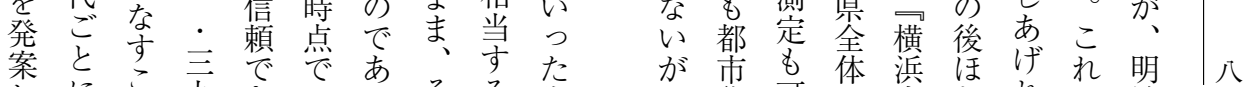

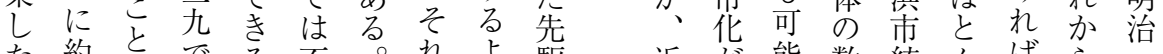

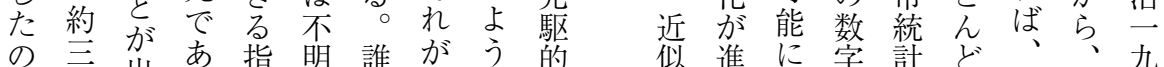

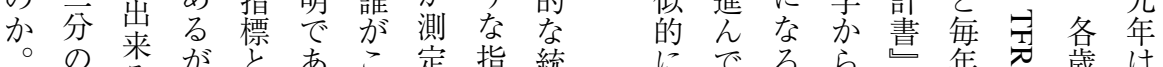
一 二 る が

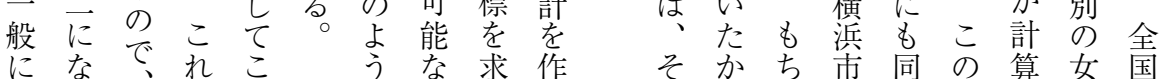


が六たう年置てのに九齢蹸報九は率通たは

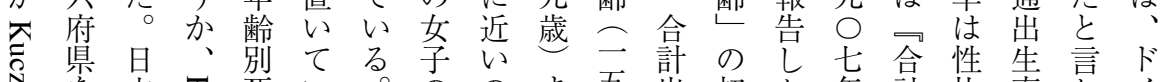
产术不死い。ののま吾出初た年計比率わイ 選で令亡るつ出でで歳生見て九出やてれッ

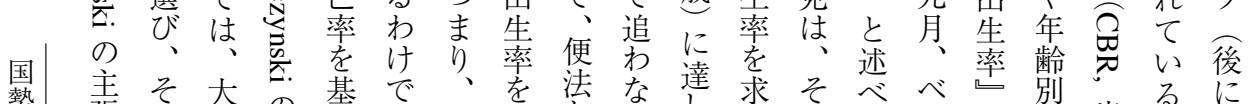

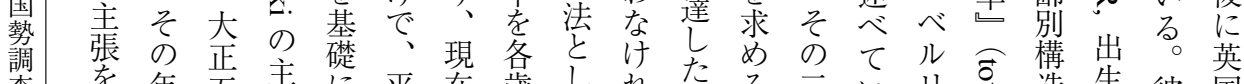

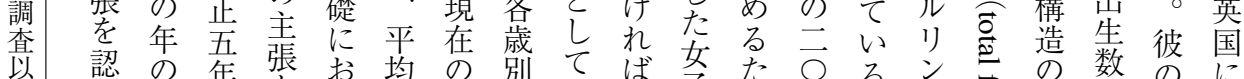

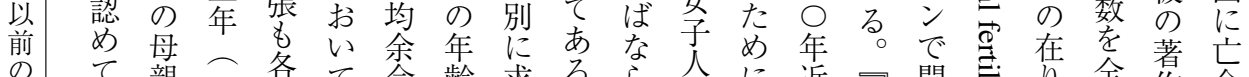

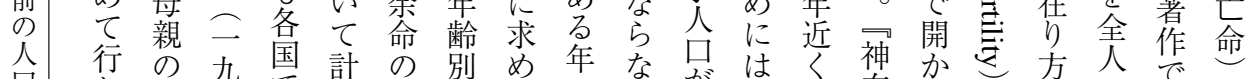

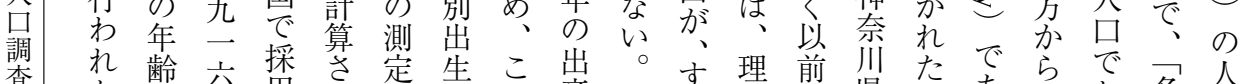

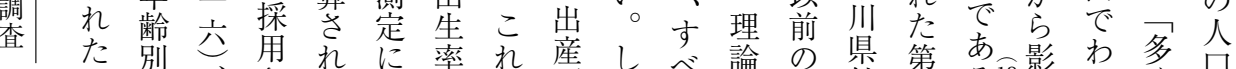

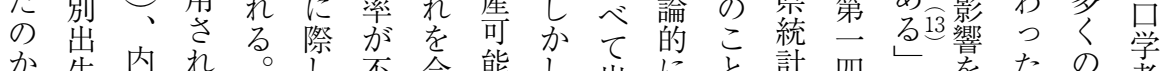

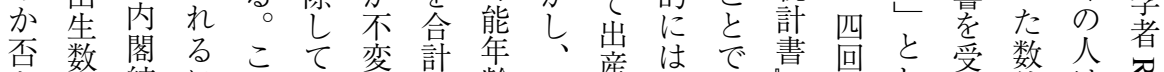

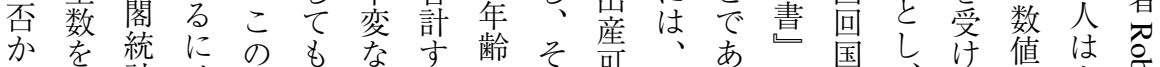

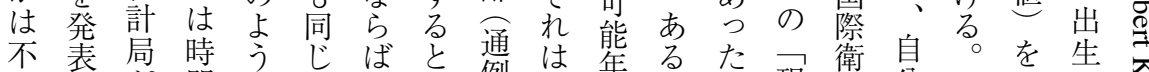

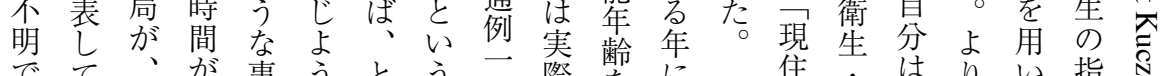
でてが事うとう五際整に住・はりい指

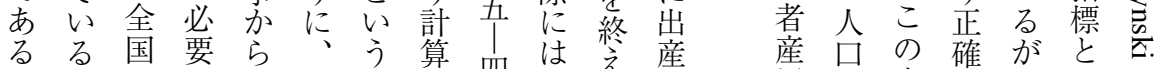
が。がで現仮算四不方生婦会事な碓がとで

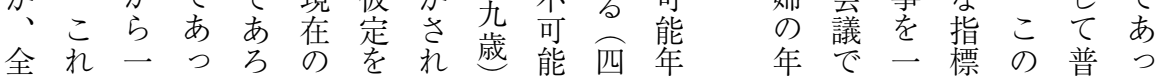

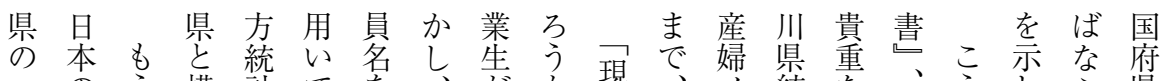

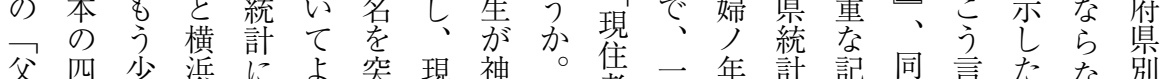

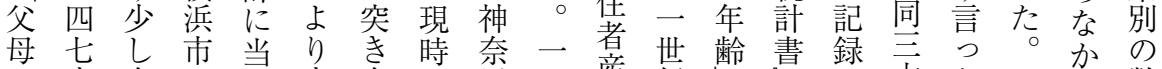

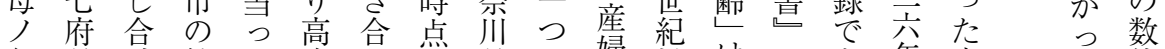

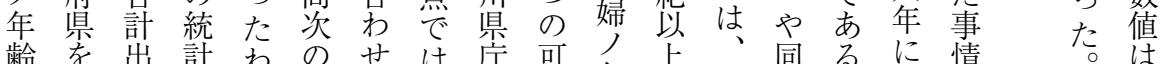

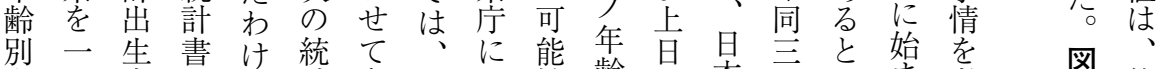

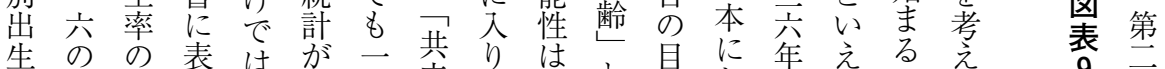

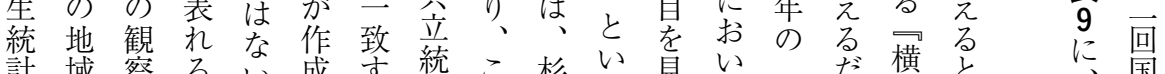
計域察る る を分続みがれ 者学表示統か発浜う統治齿查

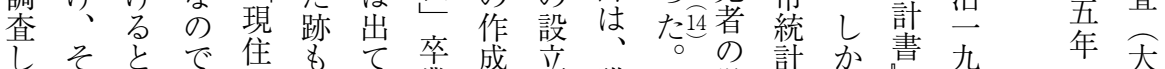

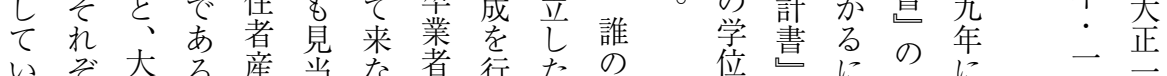

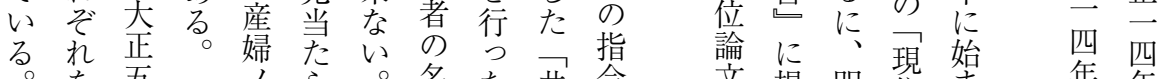

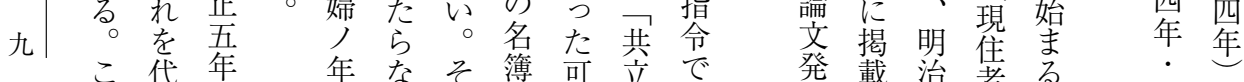
こ代年年なそ簿可咅で登載治者る 昭ま

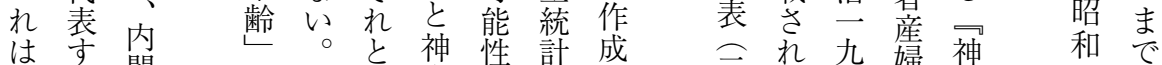

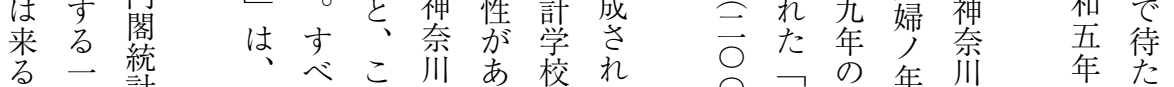

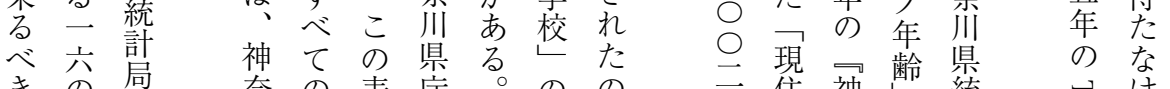

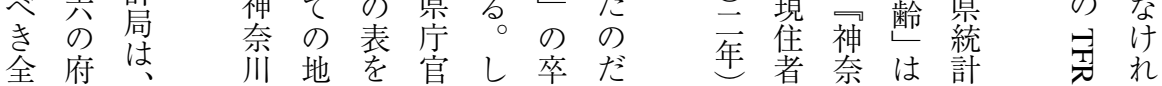




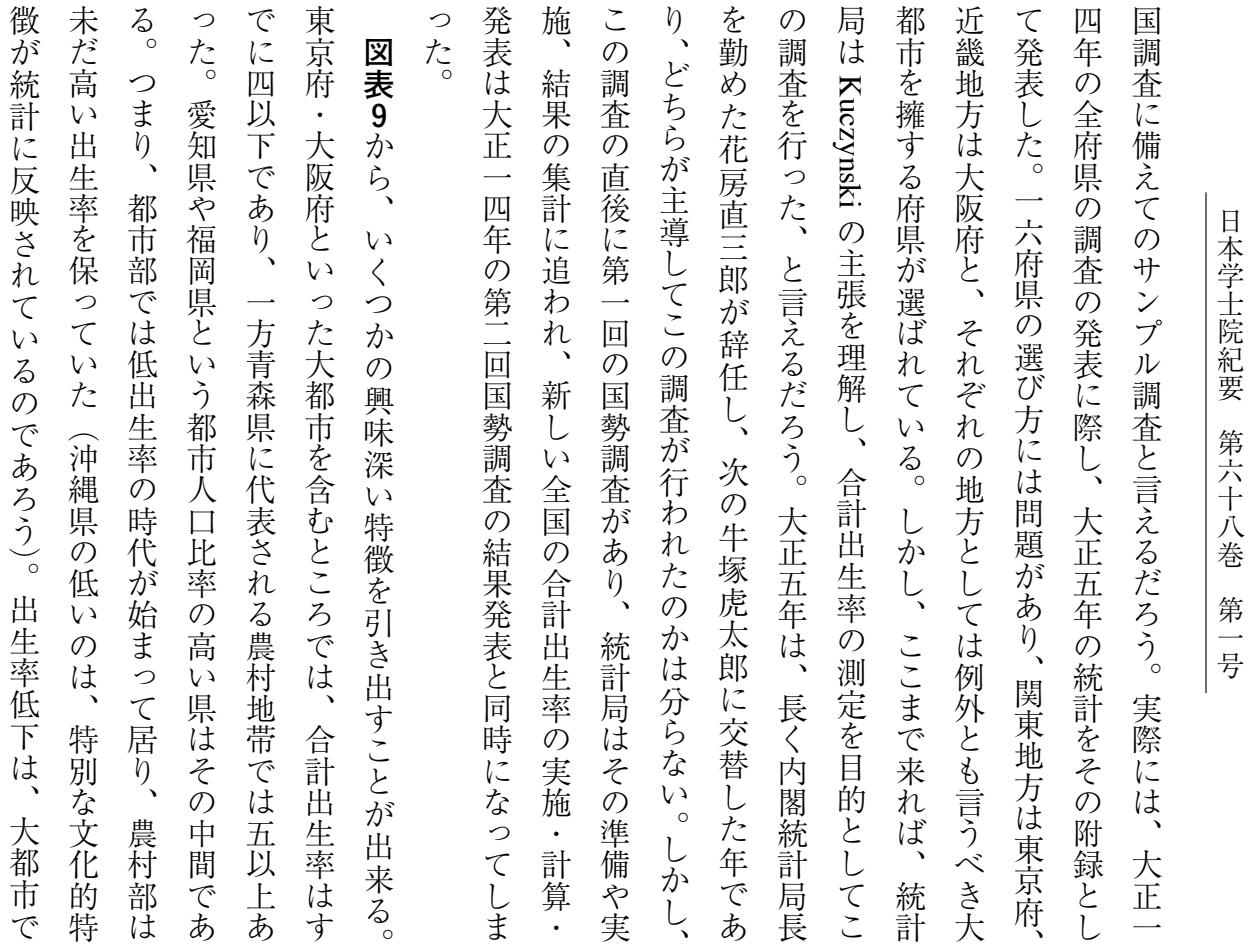

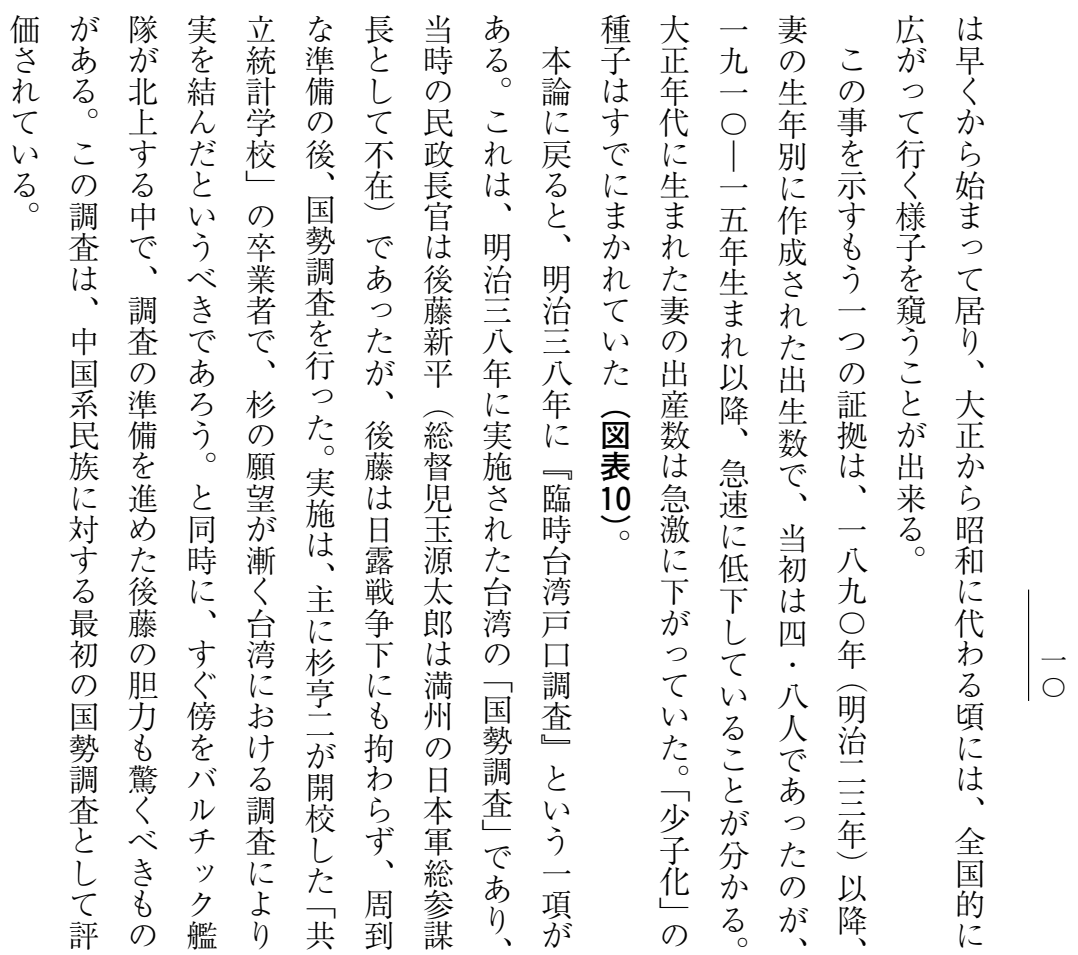


る 年 狭 間に

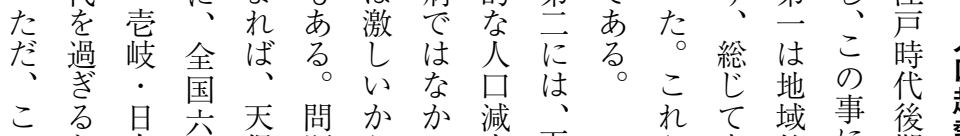

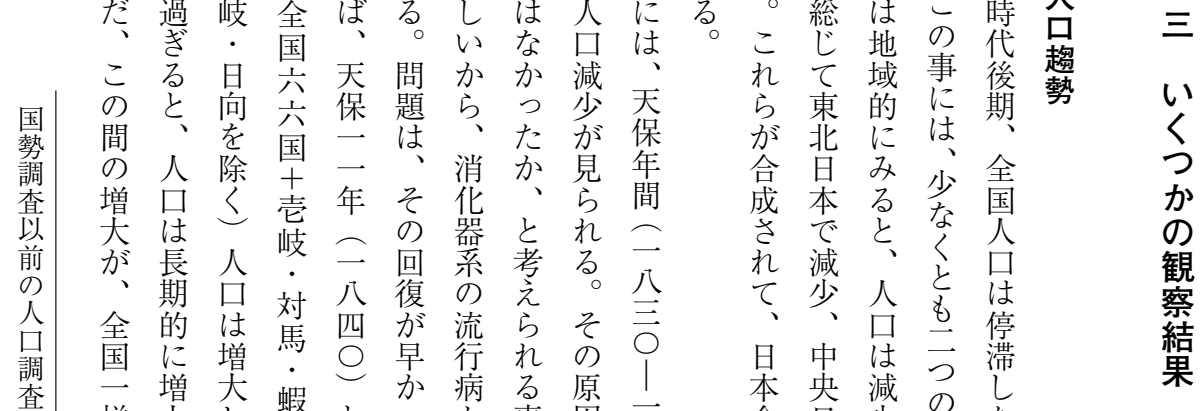

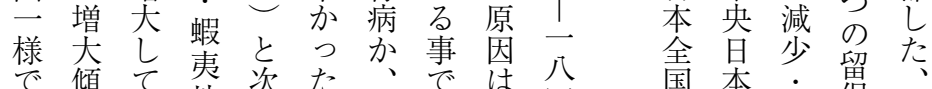

あ゙傾て 地次た事人西単四国本・留 のるの弘事ンるる單四ので停保と たあ。ほ华、フフ。飢、滞・㴆方 かつこと言幕ルと饉西仙増なの にたのん年府エく刏南停西大古が つ事事どこのンに作旦滞南の福

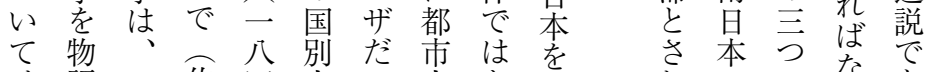

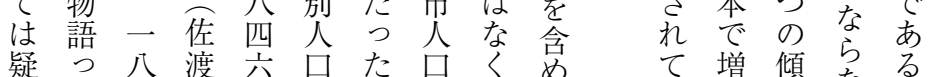

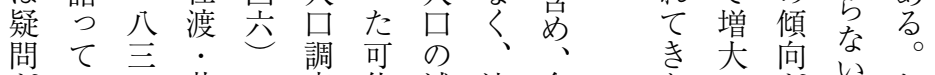
がい $\overrightarrow{0}$ 若の査能減流全たでがいし

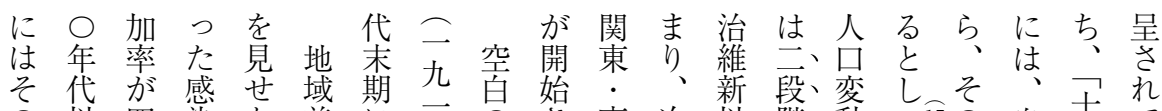

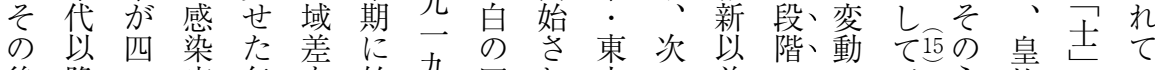

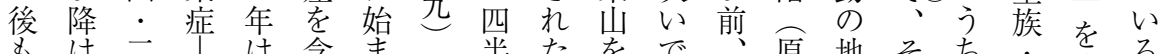
増 \% 続加にと年な人至紀で心八九者的を平族な斎

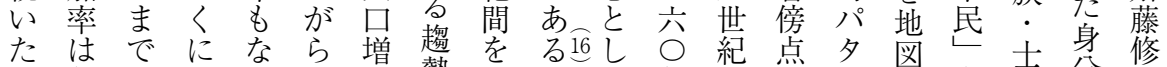

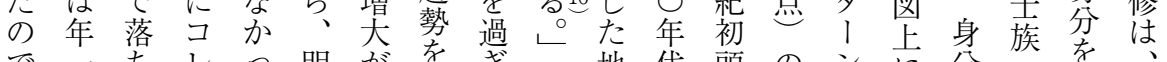

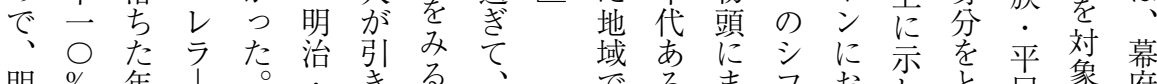
明 \% 年 五越奛に治正い图治前は北でる 次ばといし全

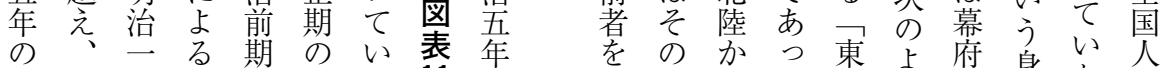

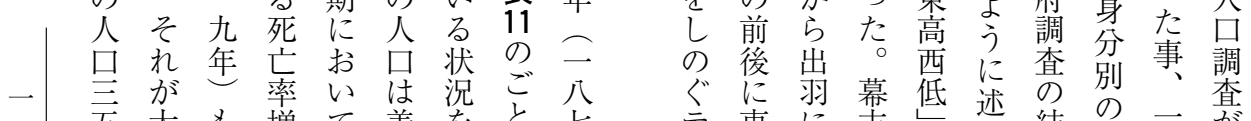
一 吾大 が 正あ大は実見くきシ東か開へで笨集方計

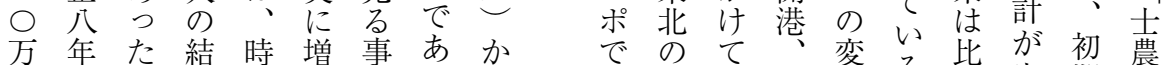
之まが果に大䖞り、ら の南のあ位る。較出期王 うで、明人本、出江正部地る域い、可て明商

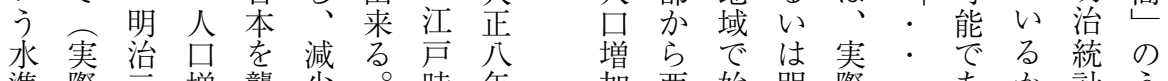
準際二増襲少。時年加西始明際・ あ 計う 


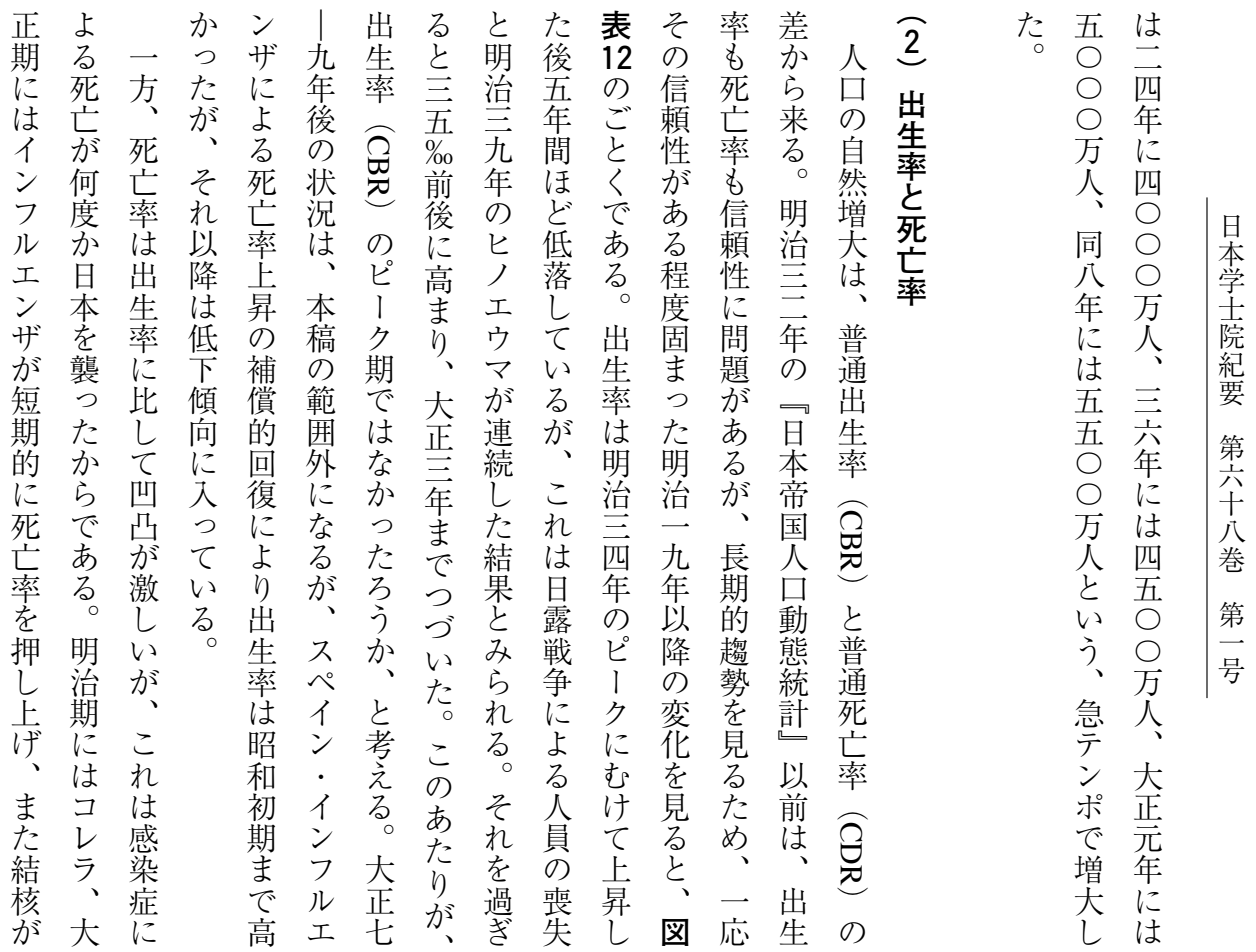

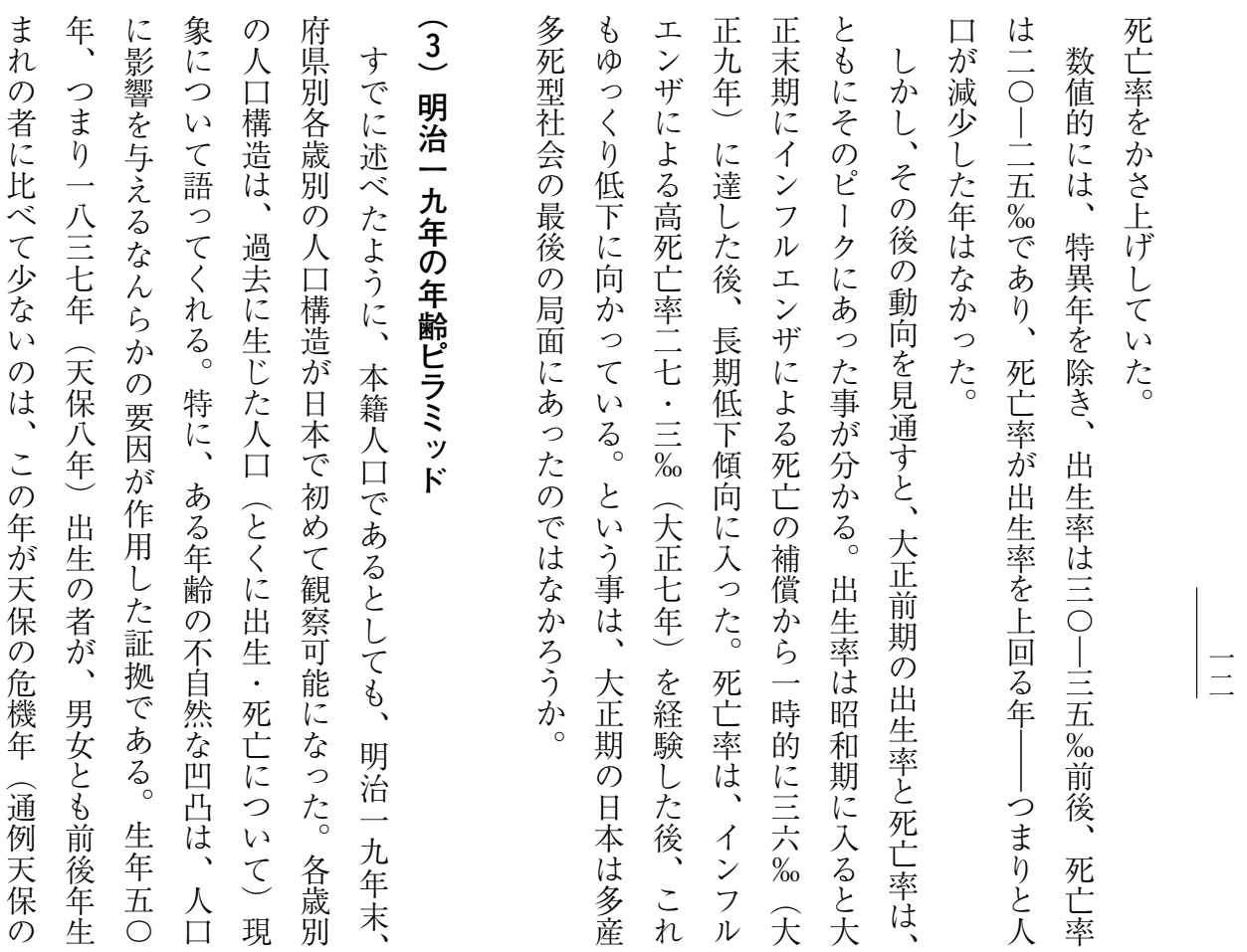




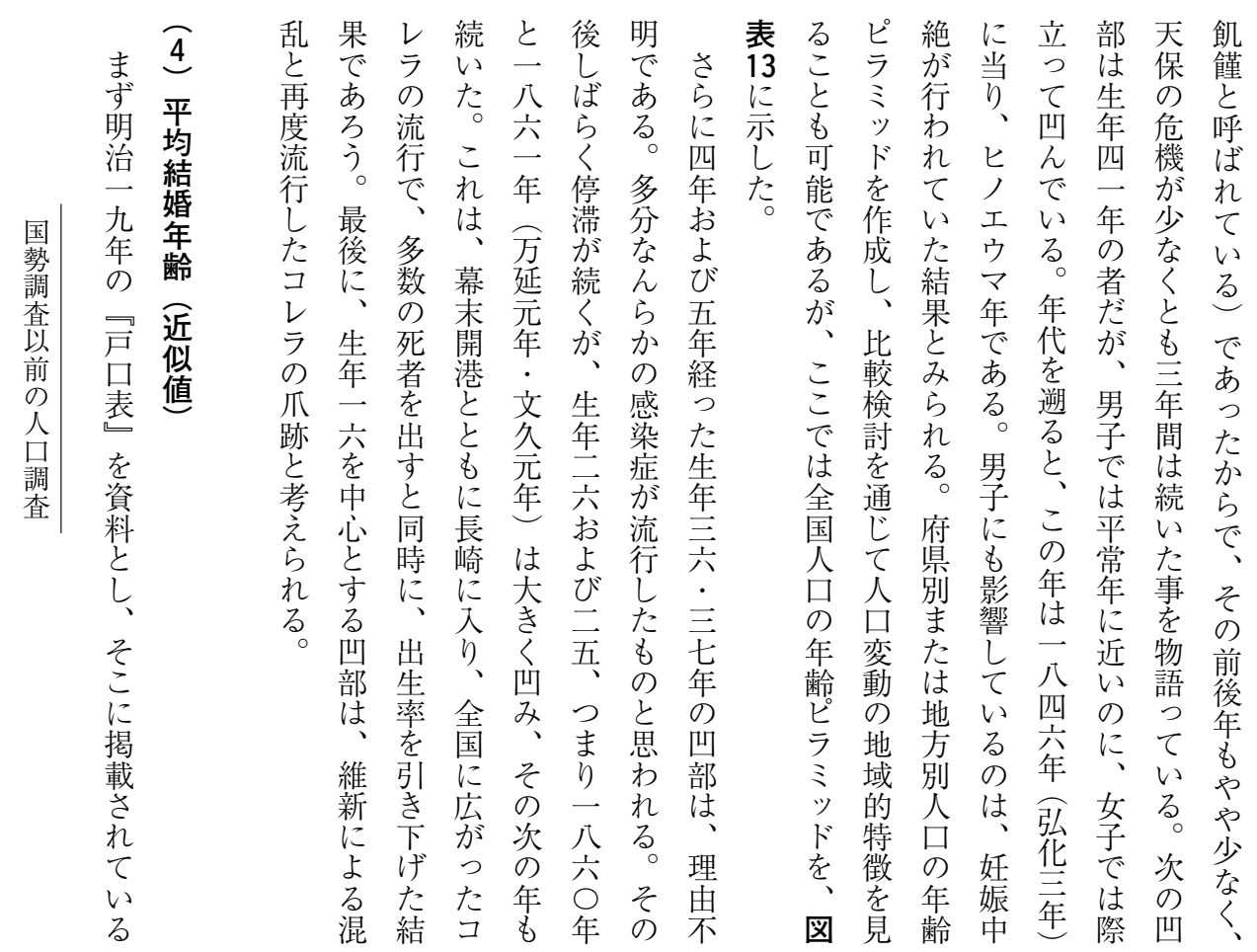




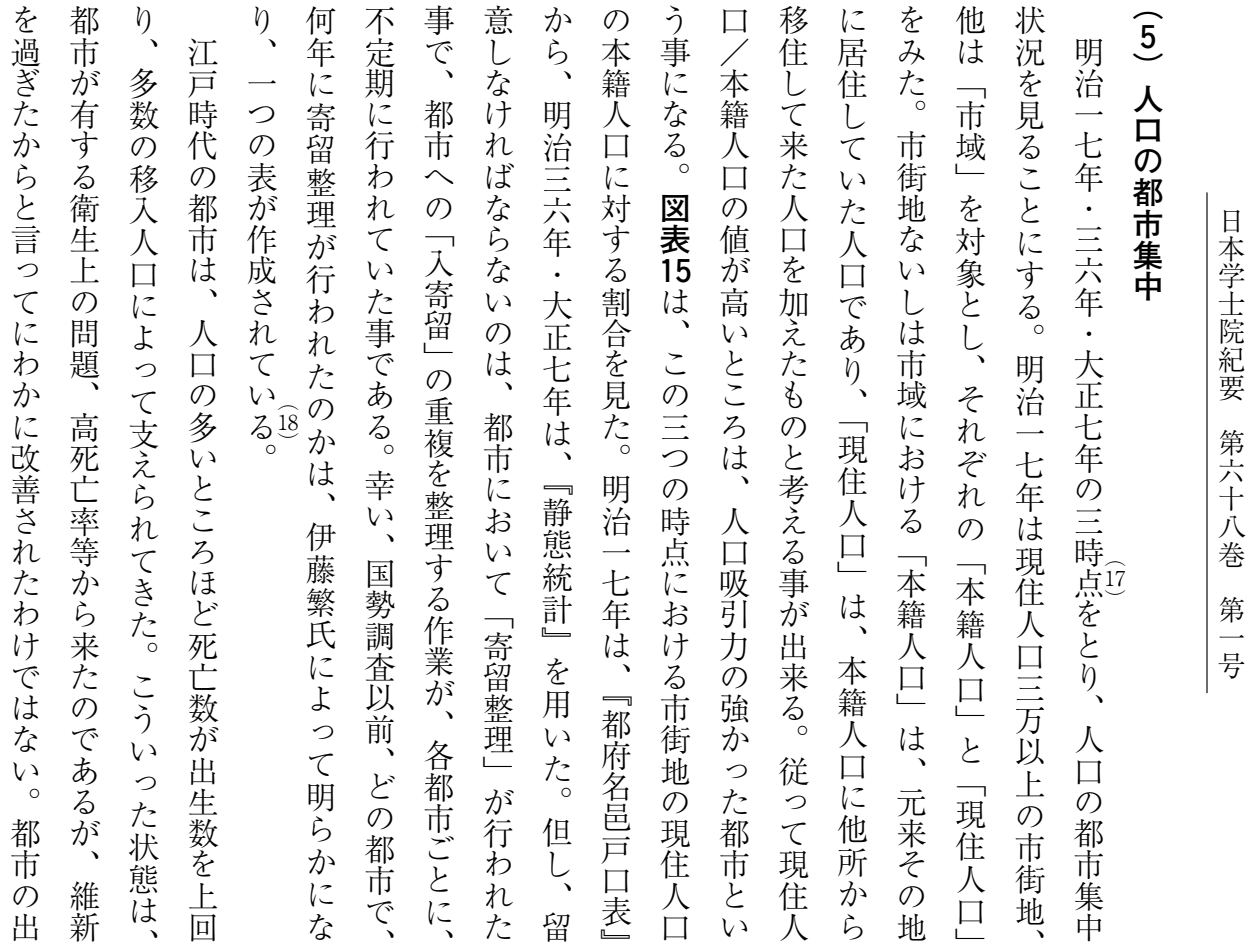

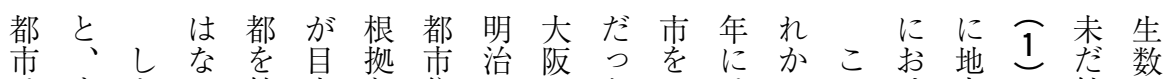
はすかい始立と住云にたみはののけ方・統・

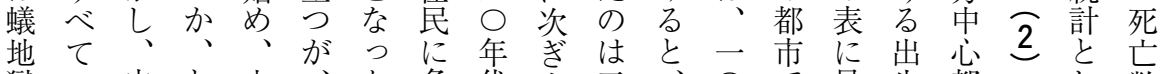

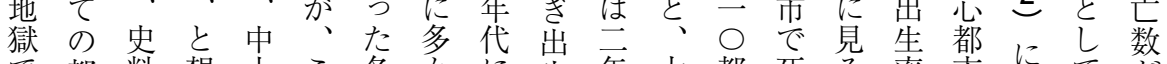
で都料想小こ各かに生年大都死る率市六て が は市 の 像都れ都つ

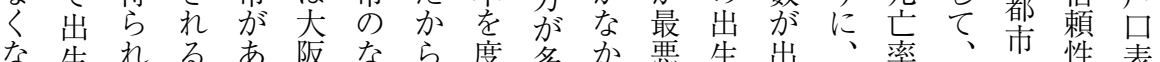
な生れ る

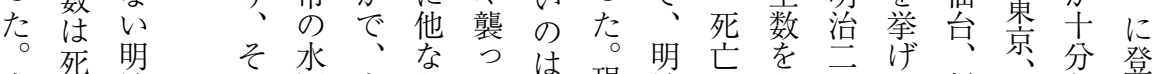

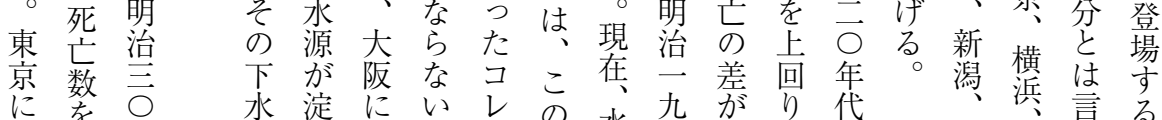

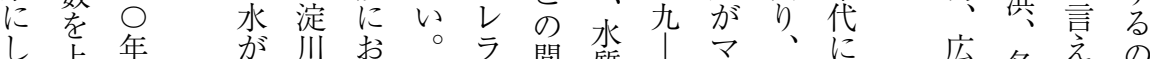

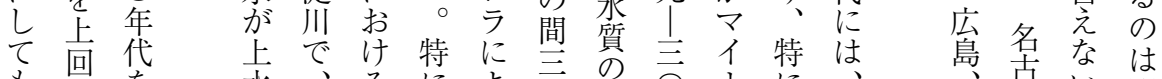

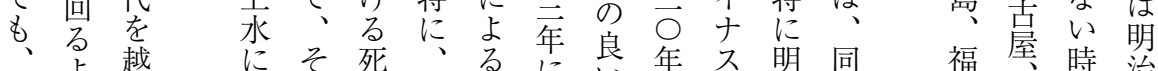

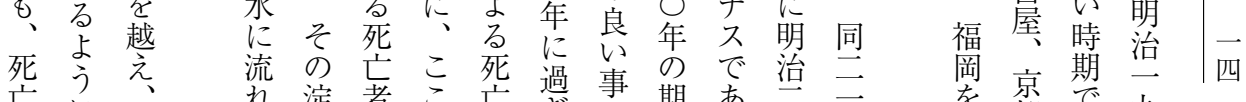

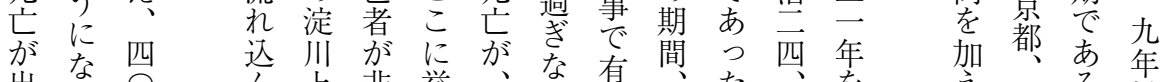

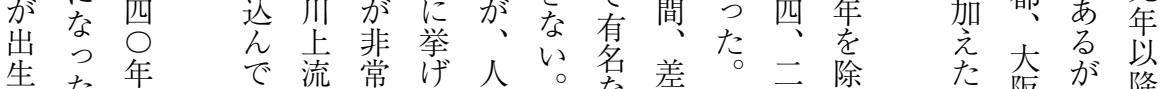

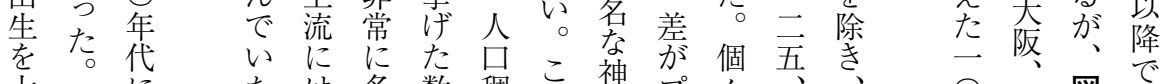

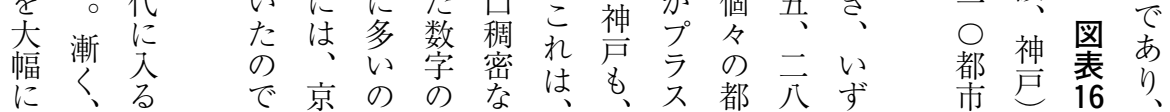




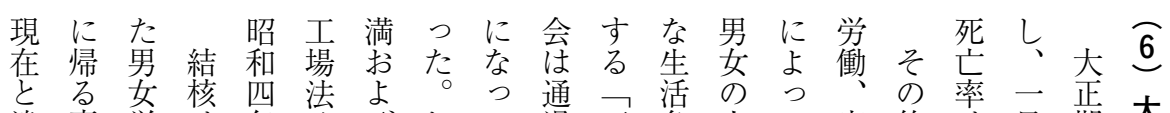

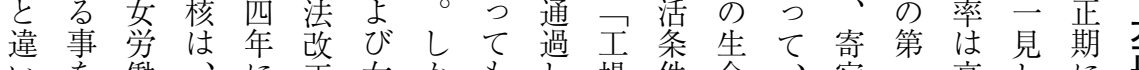
いを働、特な 正 女古も、し 場件命、宿二高しに

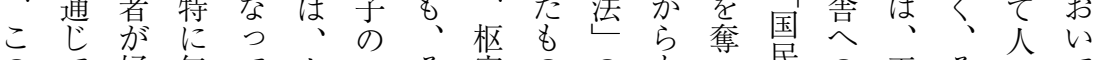

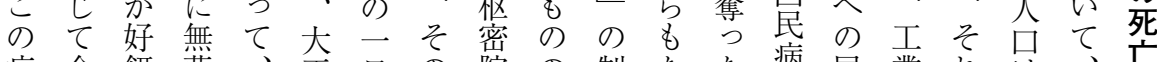
病全飭菌、正日の院の制たた病居業れ は

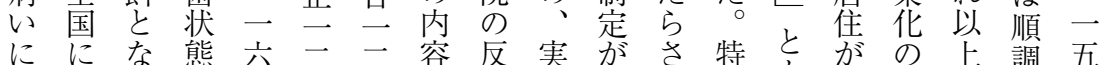
よ蔓りの歳年 時は対施叫れにも常進高に年 り延、農未に間、にはばな女習展い増間

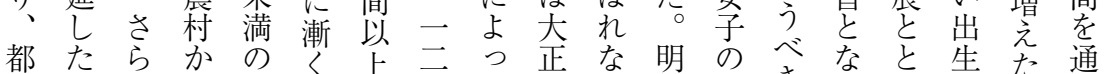
市。にら者二上歳て五が治方き方も率感芯

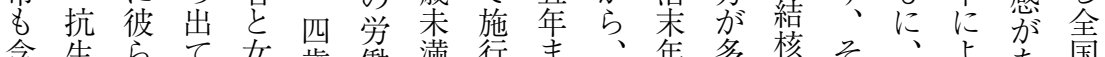
含生 らて女歲働満行ま、年多核そ文よ国

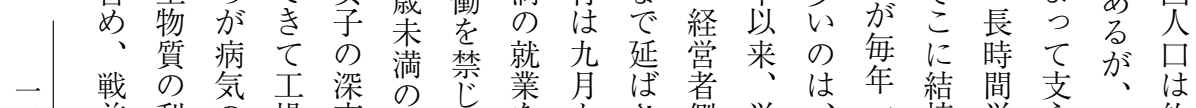

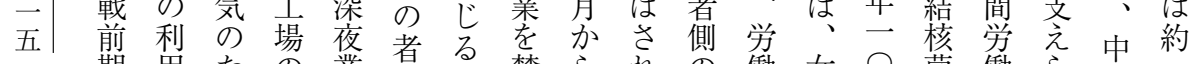
期用た

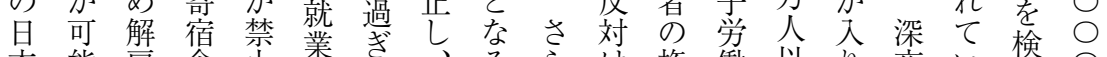
本能雇舎齿禁な、学

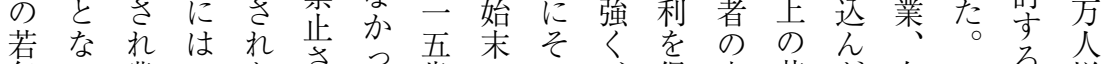

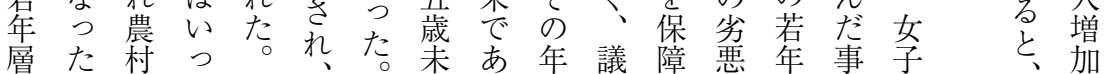




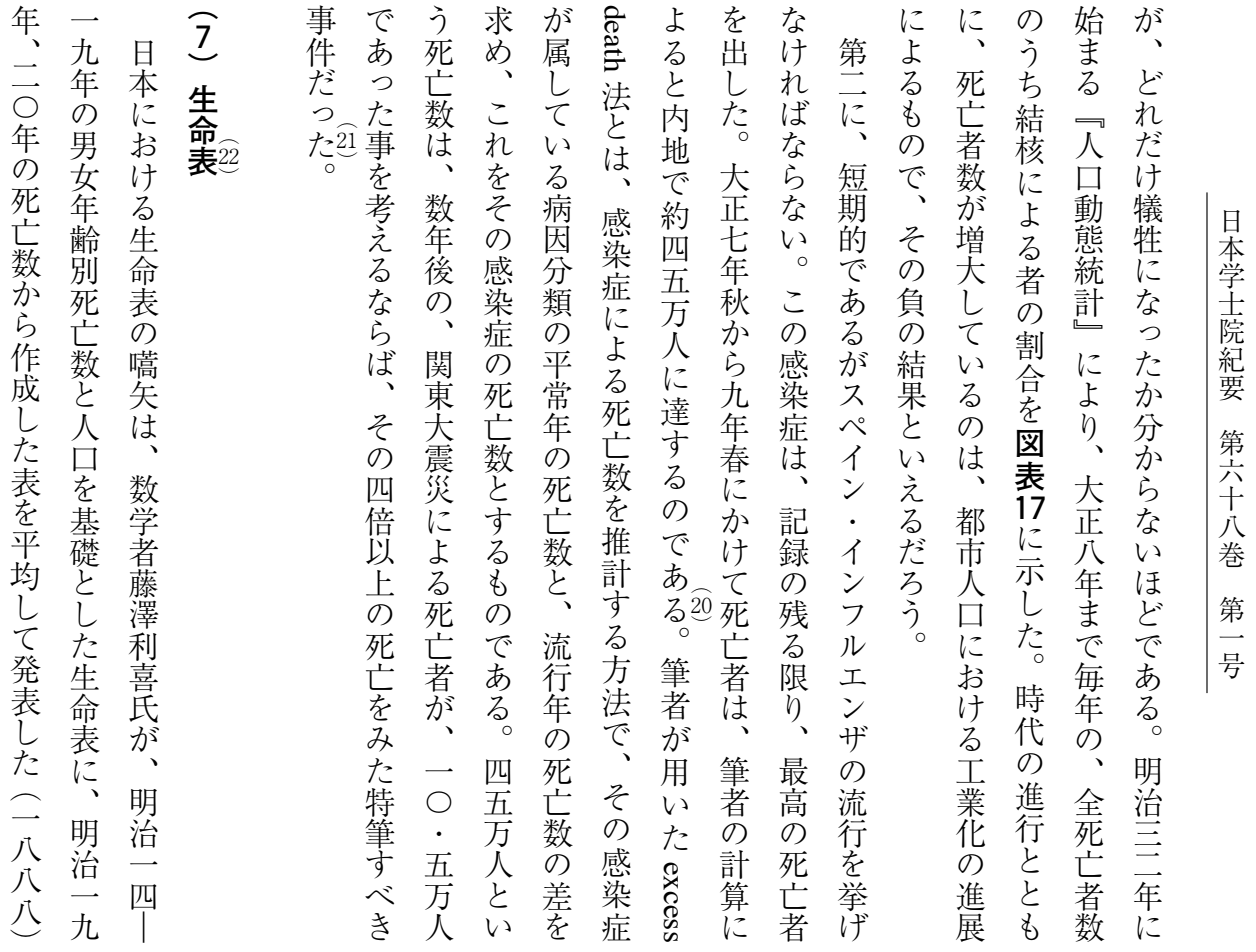

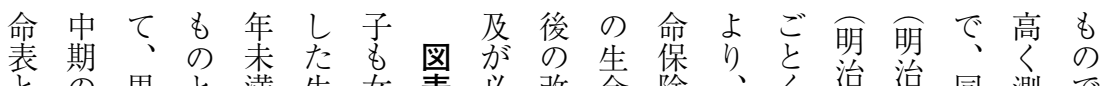
只男々満生女表必改命険、之治治同測で

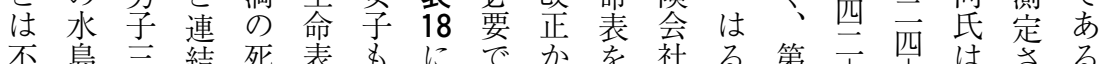

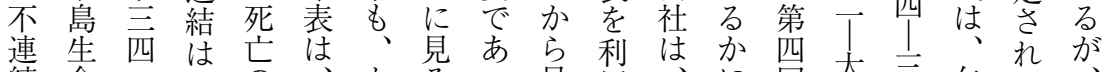

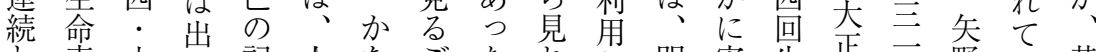

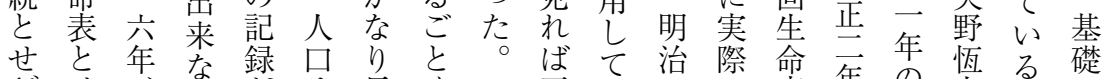

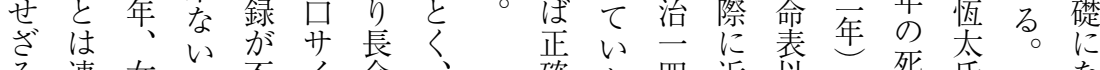

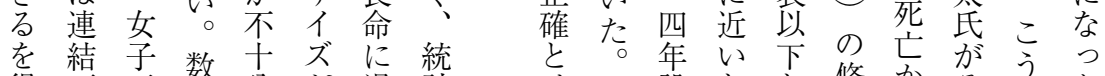

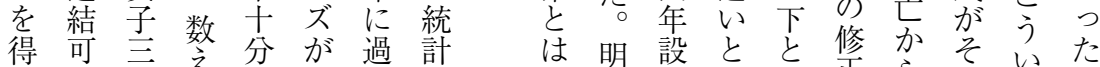
な能西齢で势局言治立思の正 5 のい統

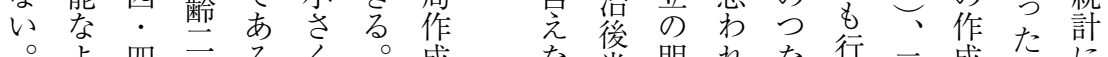

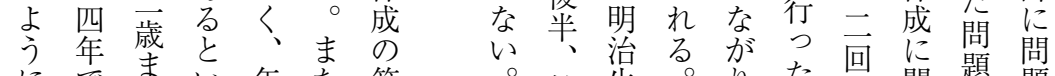

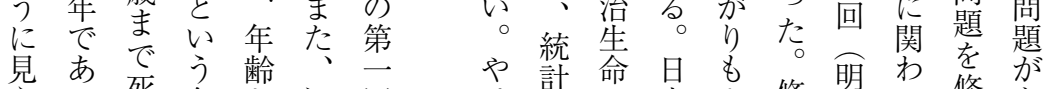

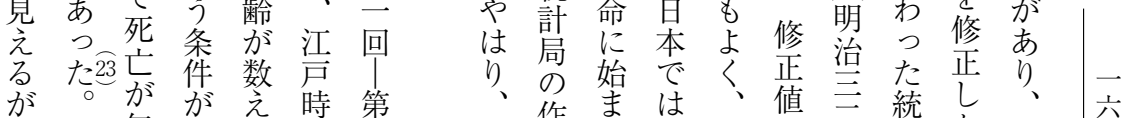
かこ無重齢代第人作ま娍統は值言統た平 統のかなでの回吕成が企計囯局の均 計水つりあ資生学た、業局图亲生が寿 局準た到り料命の生当と作表亲命水命 作はと底、㘳進告初し成18 年表島は 成、仮現生らは、歩表はてのに、第治か

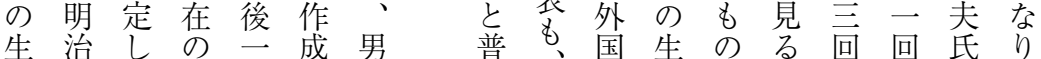




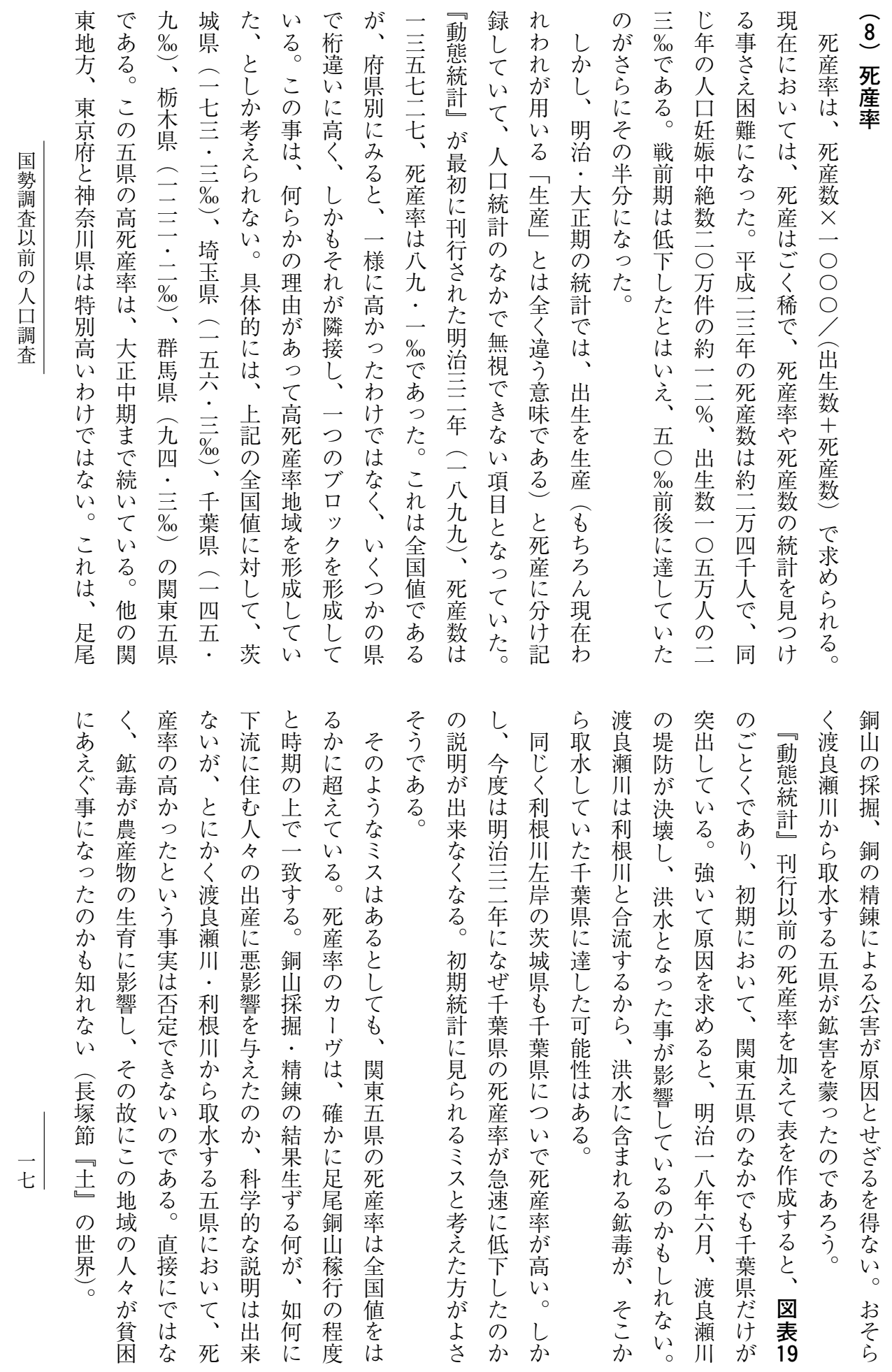




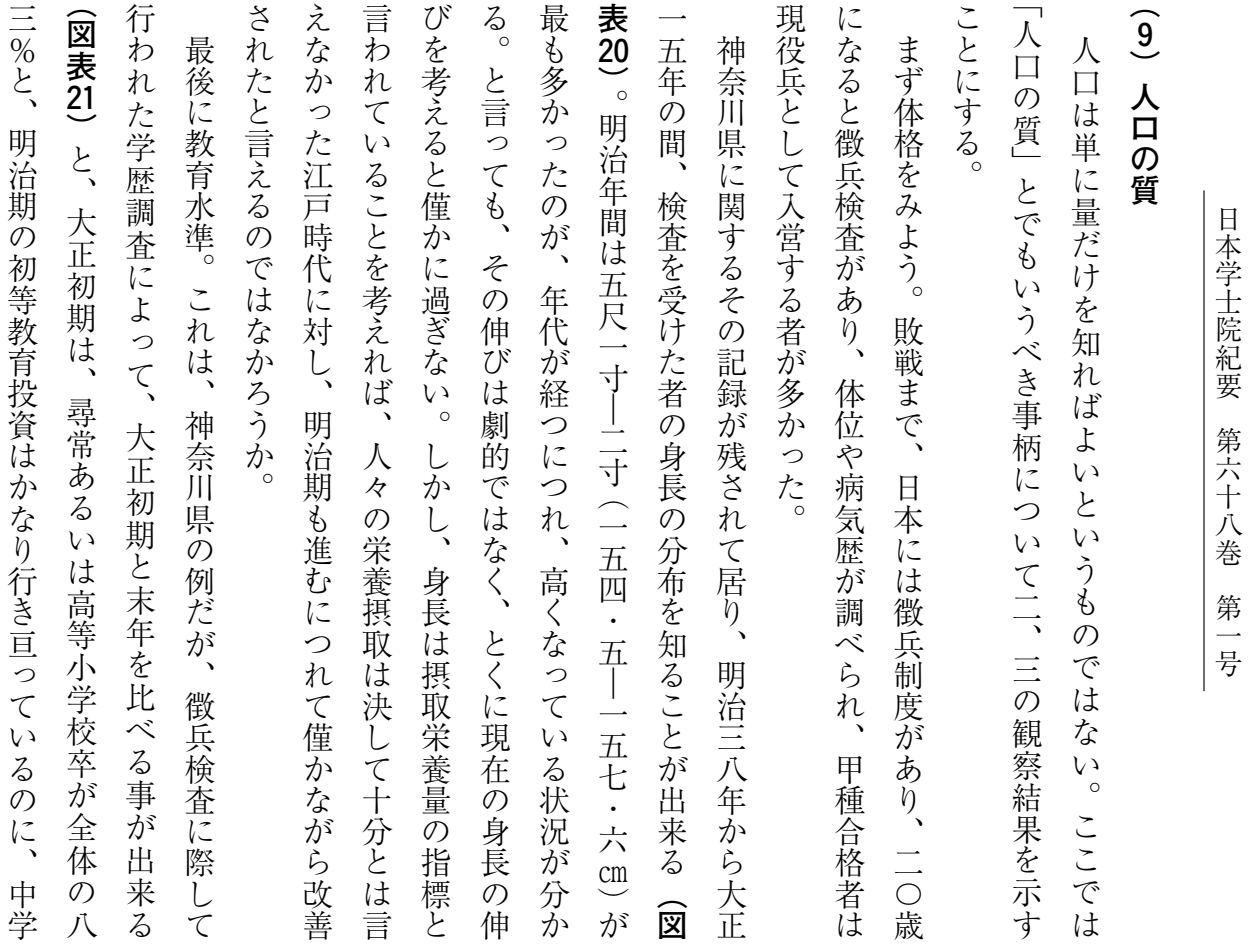

て態果津つ口な出て杉

い学た統かて適は明

る忐見原㤎計に蕃塾镸治

図离人杉深バ取入崎に

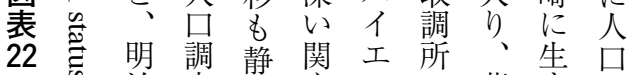

に治査岡心ルに蘭ま統

そな政 た孝之席学れ計

のど、府政移持州を学通関

部近行作り、占国牦学詞祭

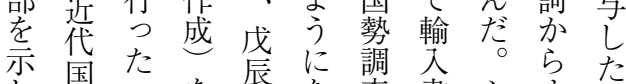

た 勢 戸 を戦 な

査籍つ争。関触て ン 物

にとた 兵維るす扎幕名し

酷は残炎新る る 直 機に府語て

似異外が後書会取習己

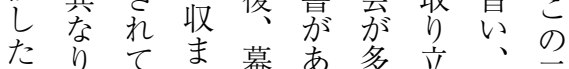

たり調り、心

査職るぬ梳なら幕を

容業导内静統つれた岡計た 挙

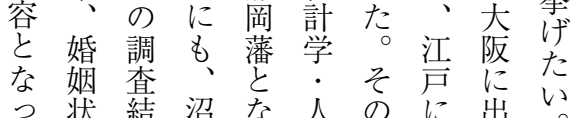

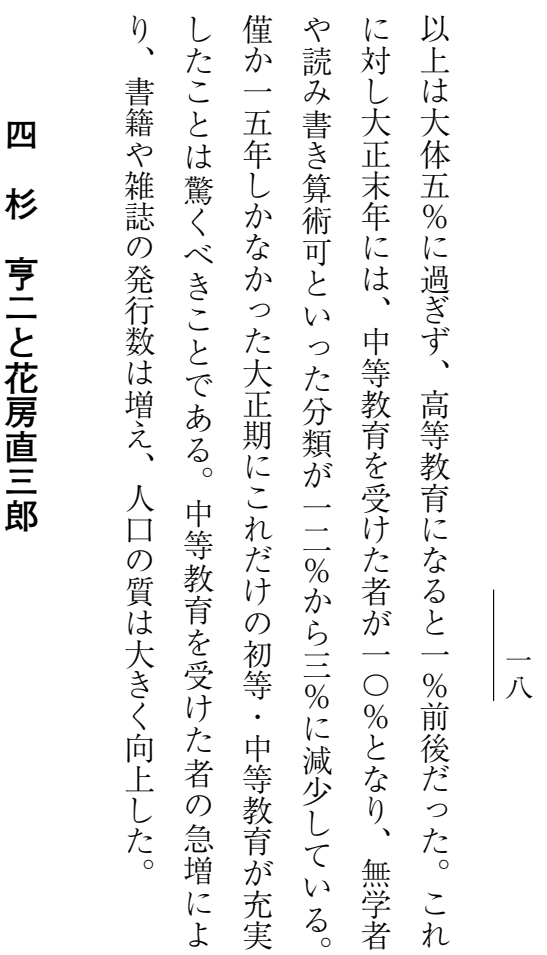




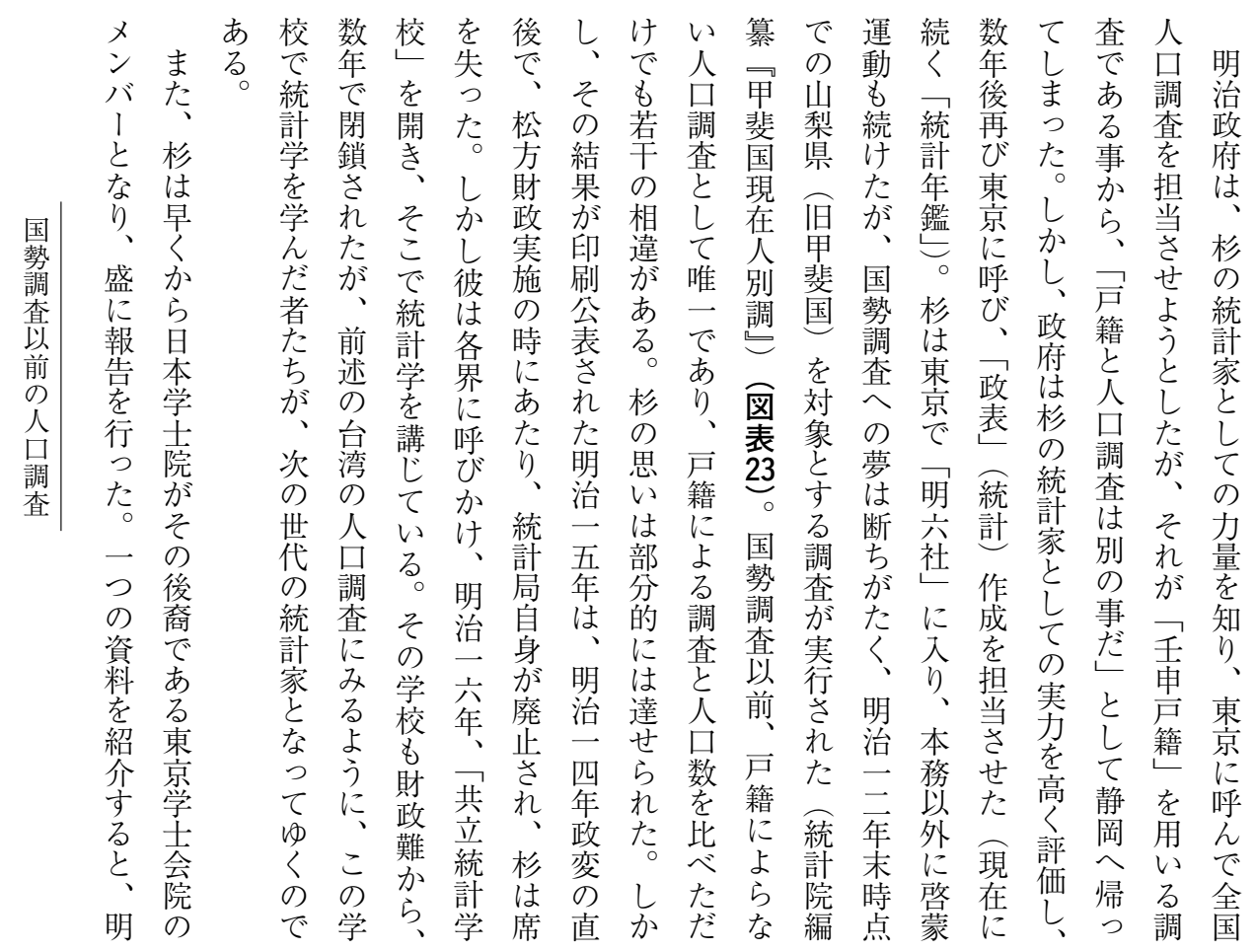

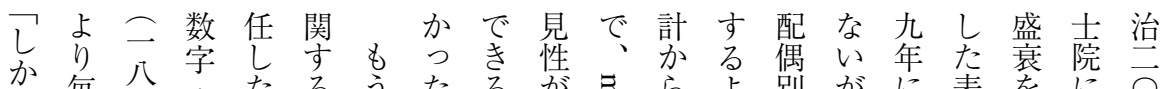

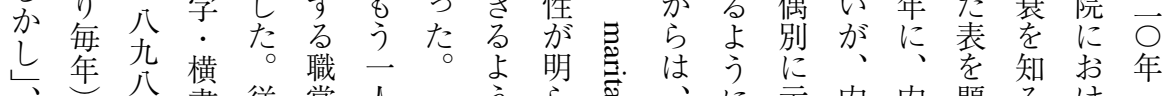

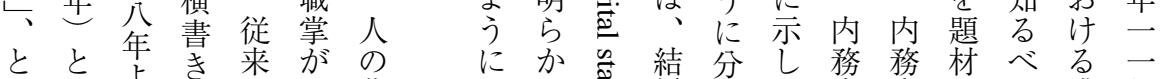

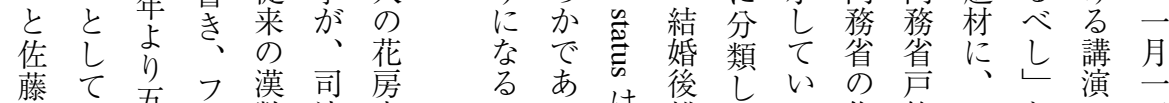

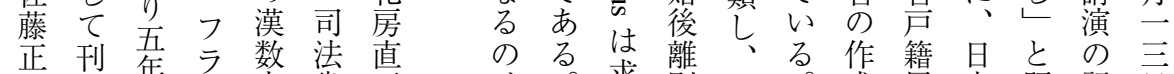

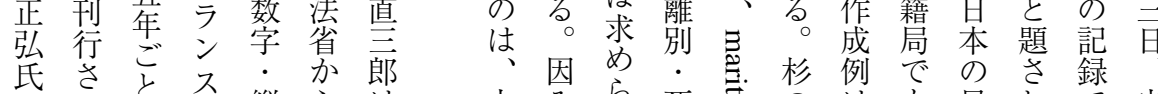

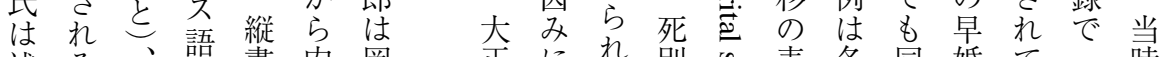
述る、語書内同正に杂別表各同婚て時

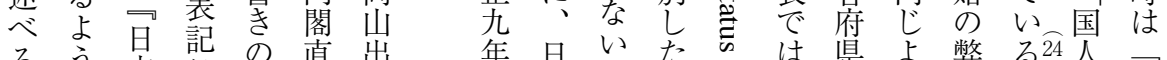
るう本付の直出身年杂。者がは県よ嫳る。望身東

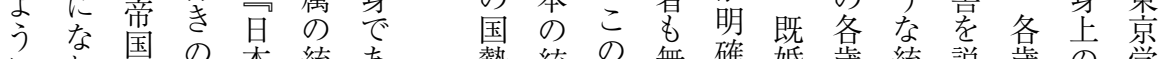
にり全の本統あ勢 統 事橆確婚歳統説歳の学

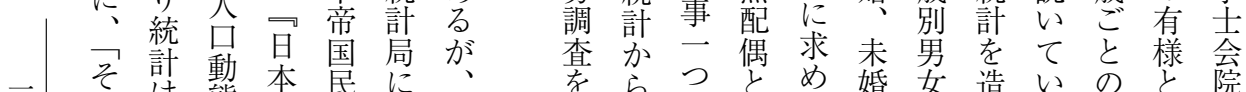

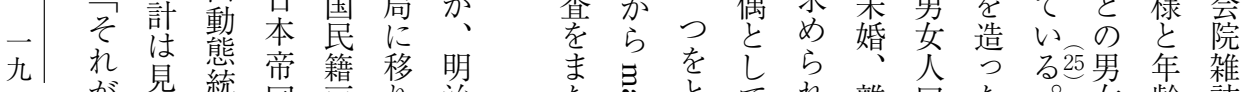
が見統帝籍移明ま寻をしら煶人气 る25男年雑

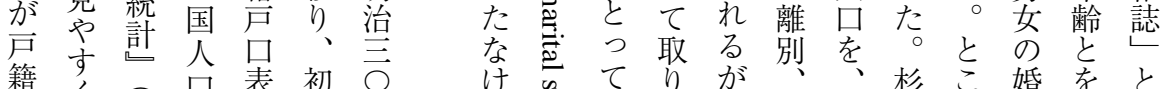

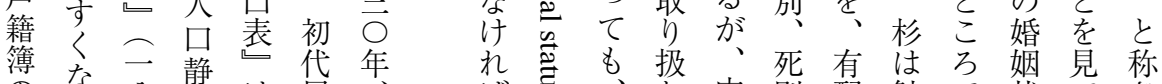

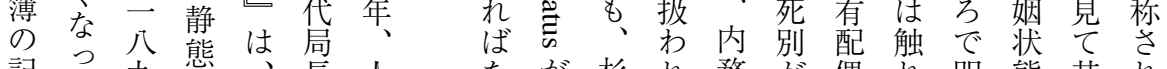

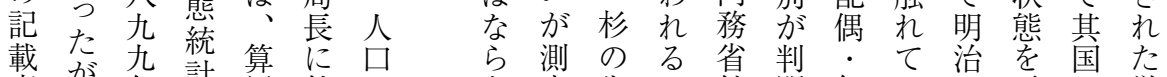

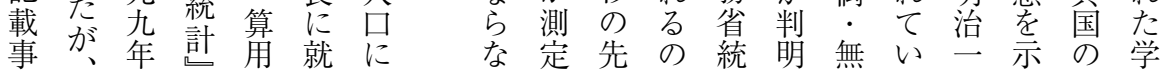




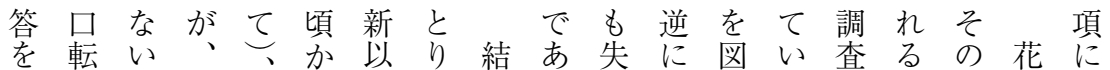
用換しいとら後入局るし改つる索通こ房依

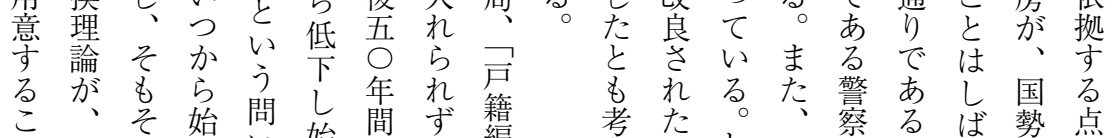

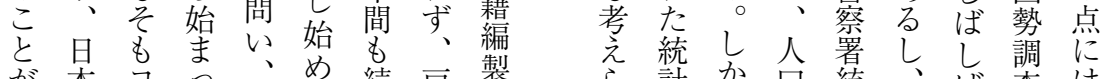
が本当つ、め続戸製占計か口統、ば查は

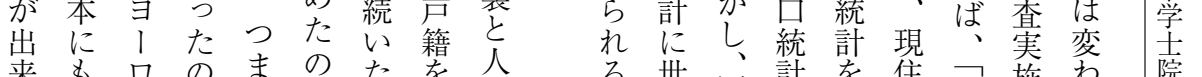
な来 も蔐ツ

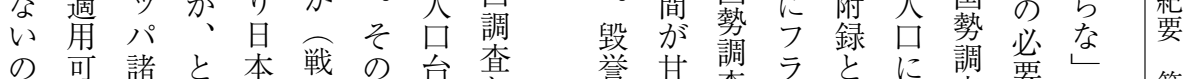
で能国いの争結帳と あな劣方人直果筧告異

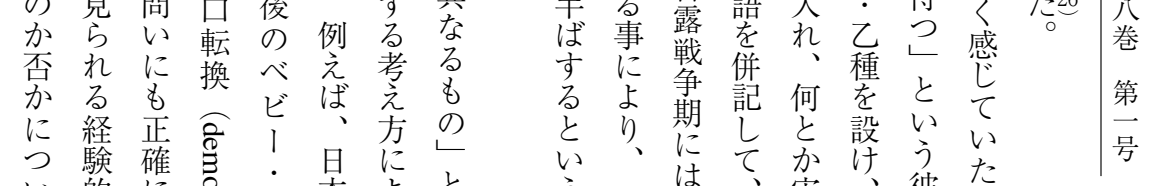

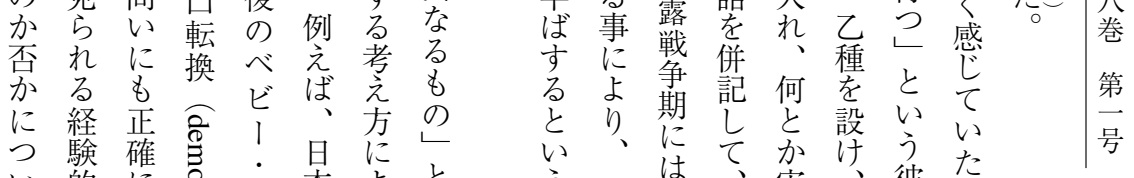

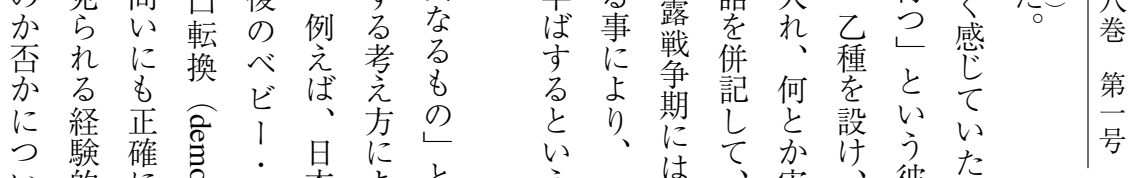

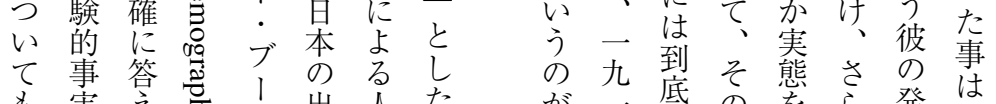

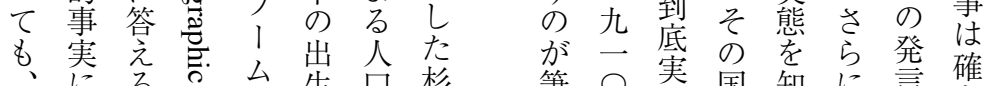

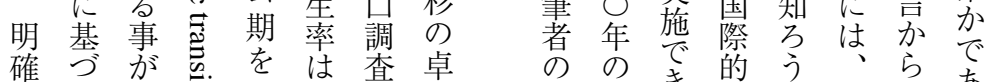

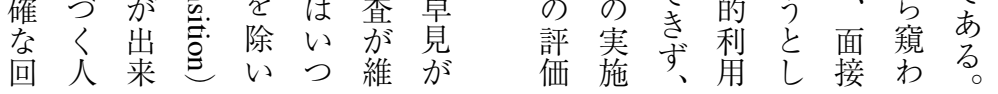

うい神りな的だに映っ計戸た 戸 点が莠去しい前か重なしでは籍明籍結 貴そ県こし刊事でたくく可基治基、

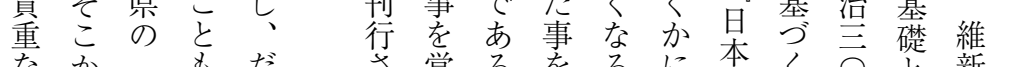

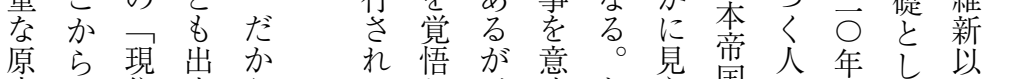
原今珼出か 来ら悟が意々見国人年し吕 で著なといな日守い方全統とた約

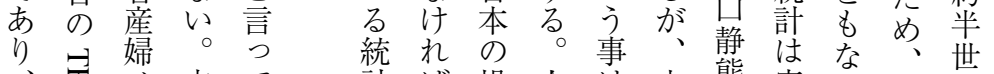

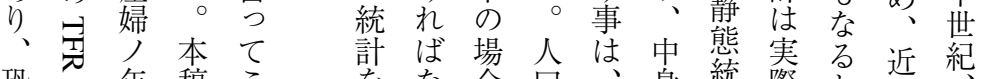

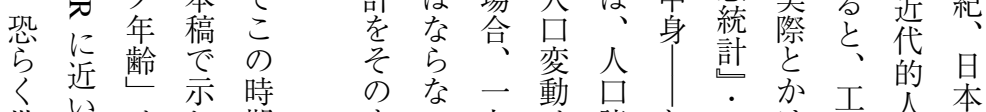
世統はし期まい九は諸と㮏け業人の 界統はた等のの变々動離羍口調人

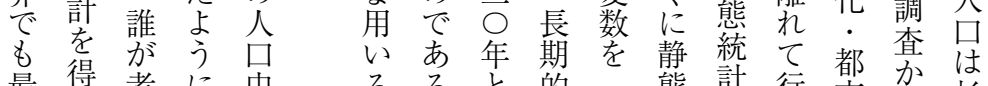

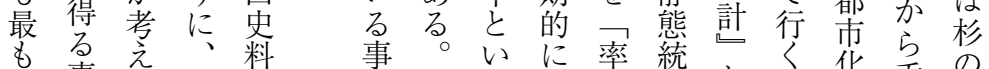
早事隹明料事少う観率統々く。化乘指

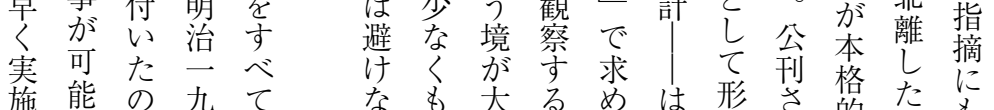

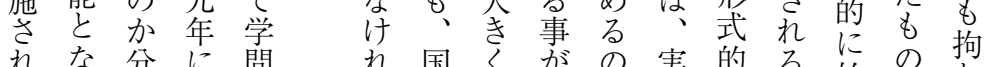

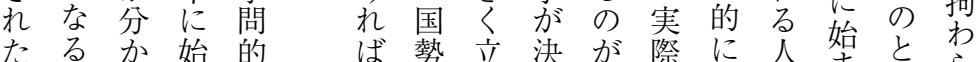
調々 

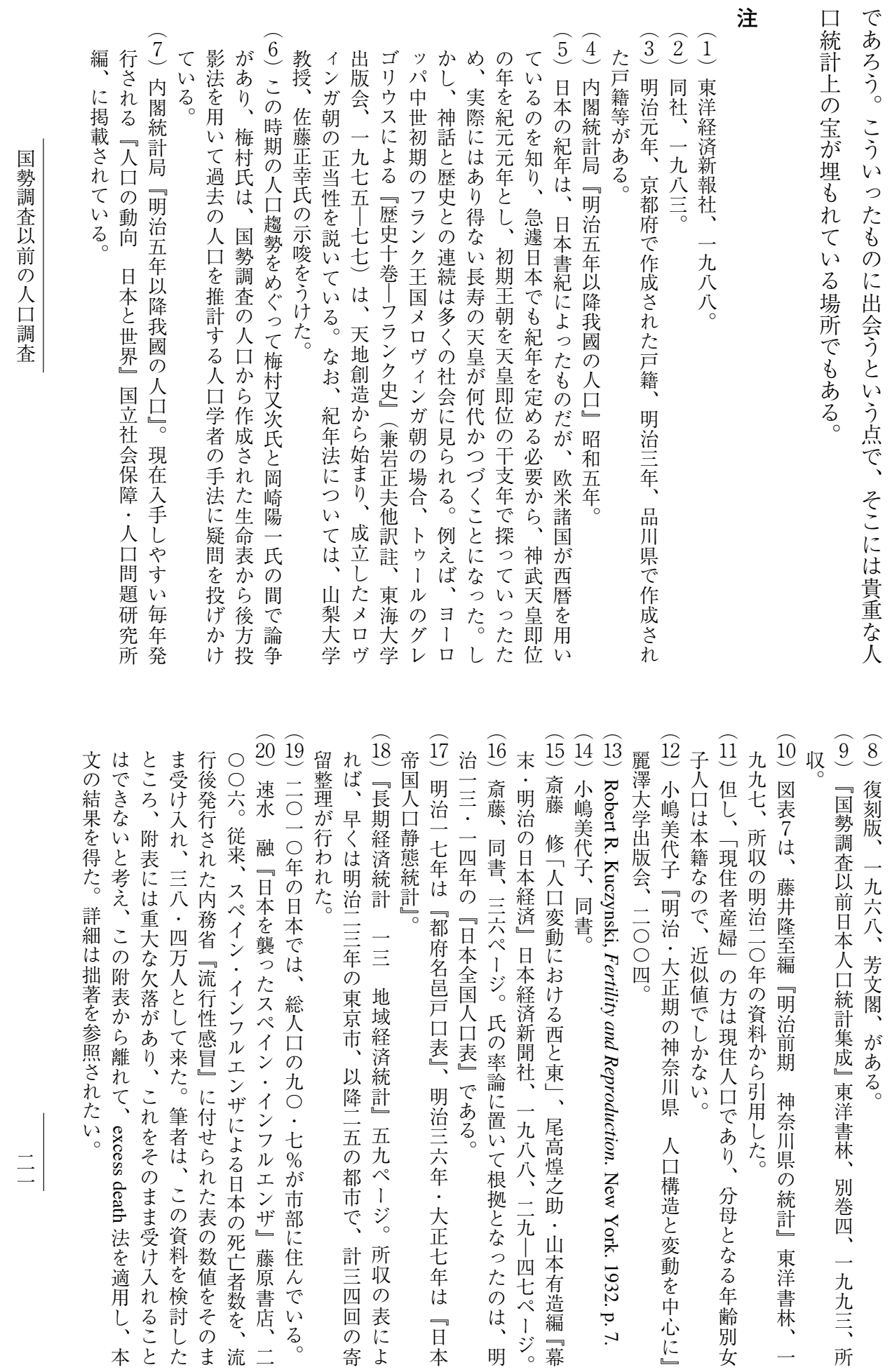


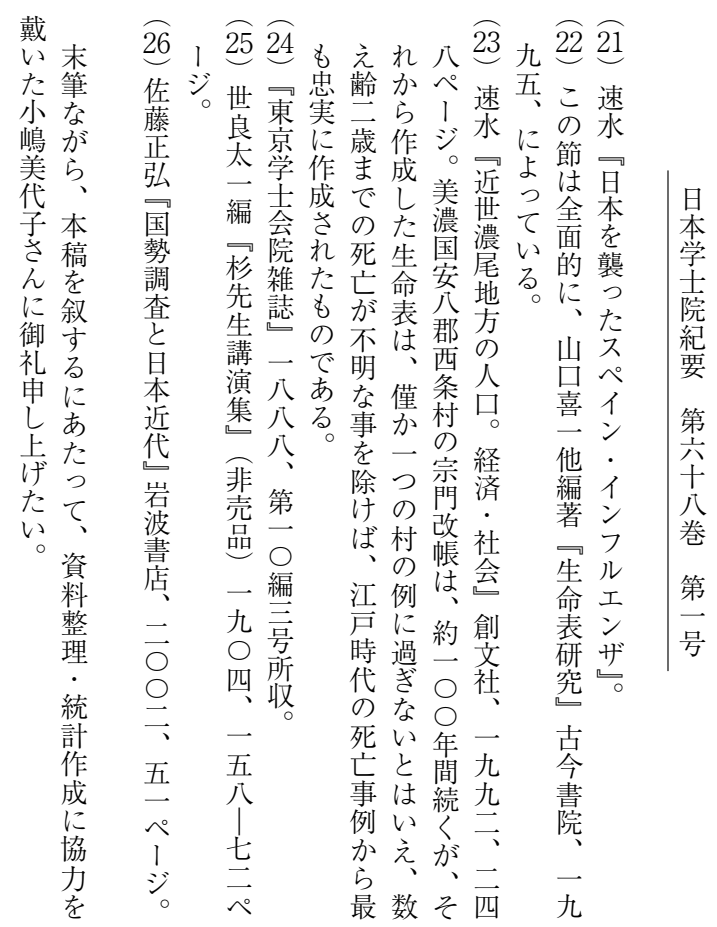


図表 1 明治 5 年『日本全国戸籍表』

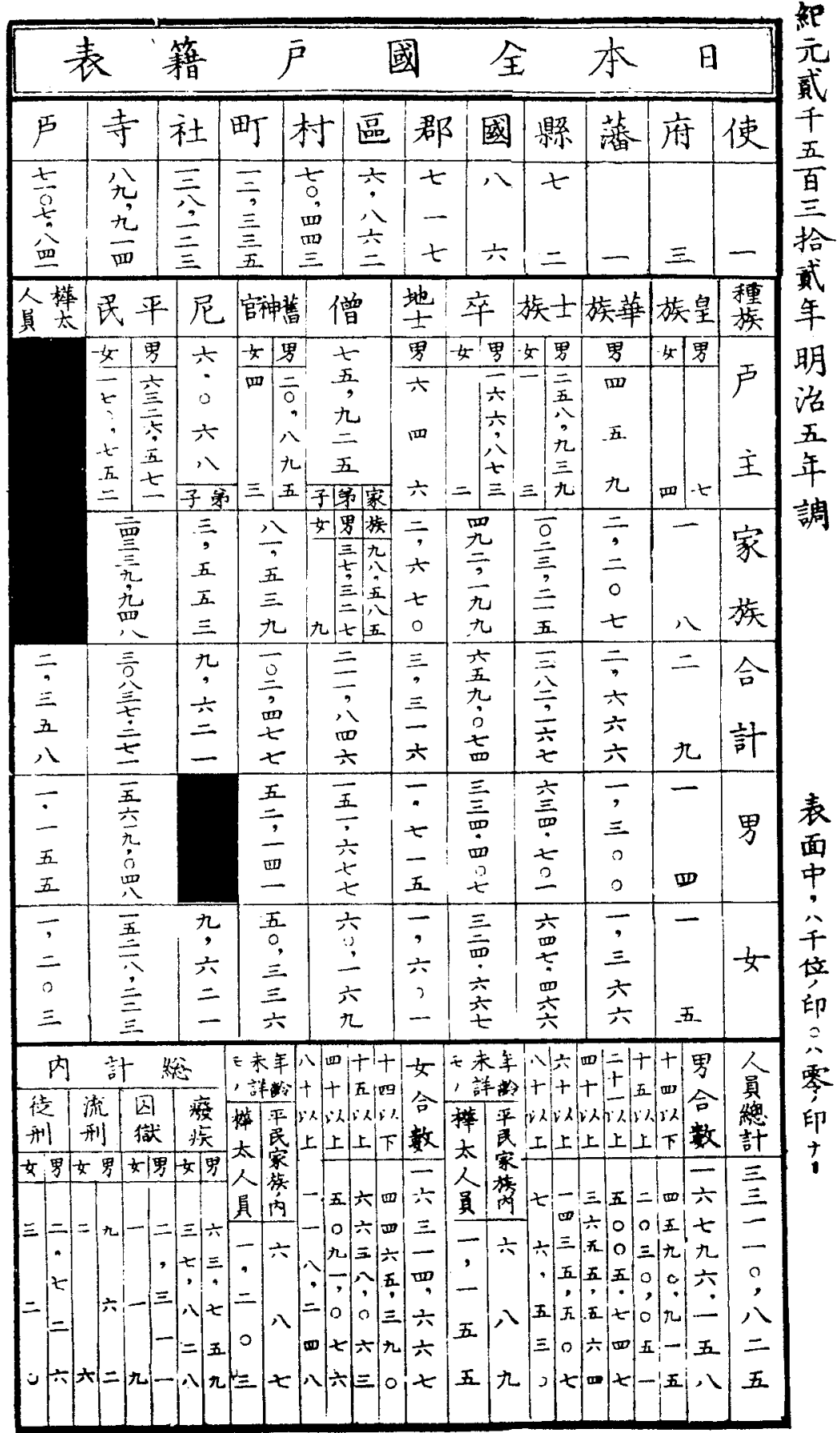


図表 2 明治13年『日本全国人口表』

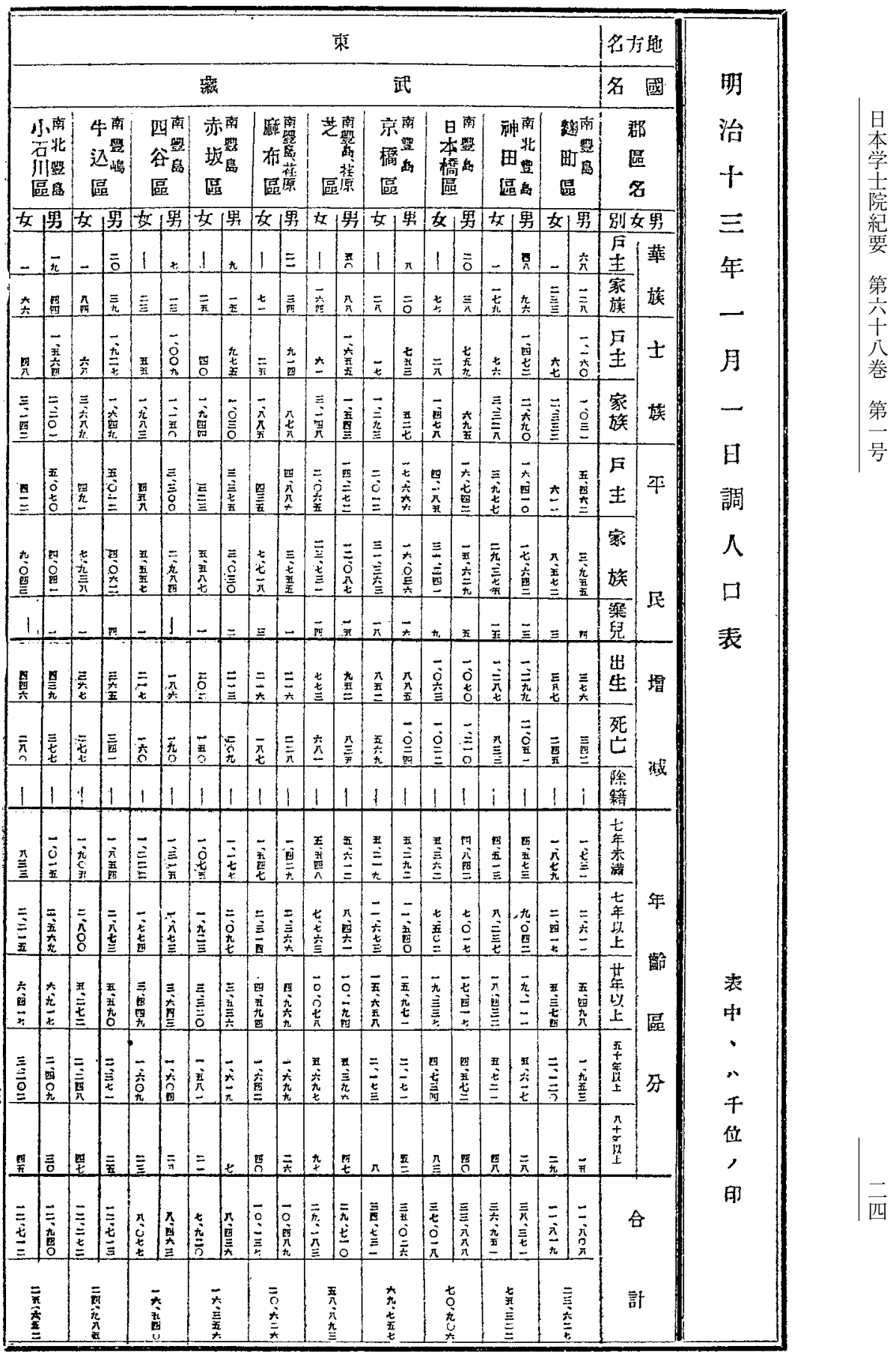


図表 3 明治19年末『日本帝国民籍戸口表』

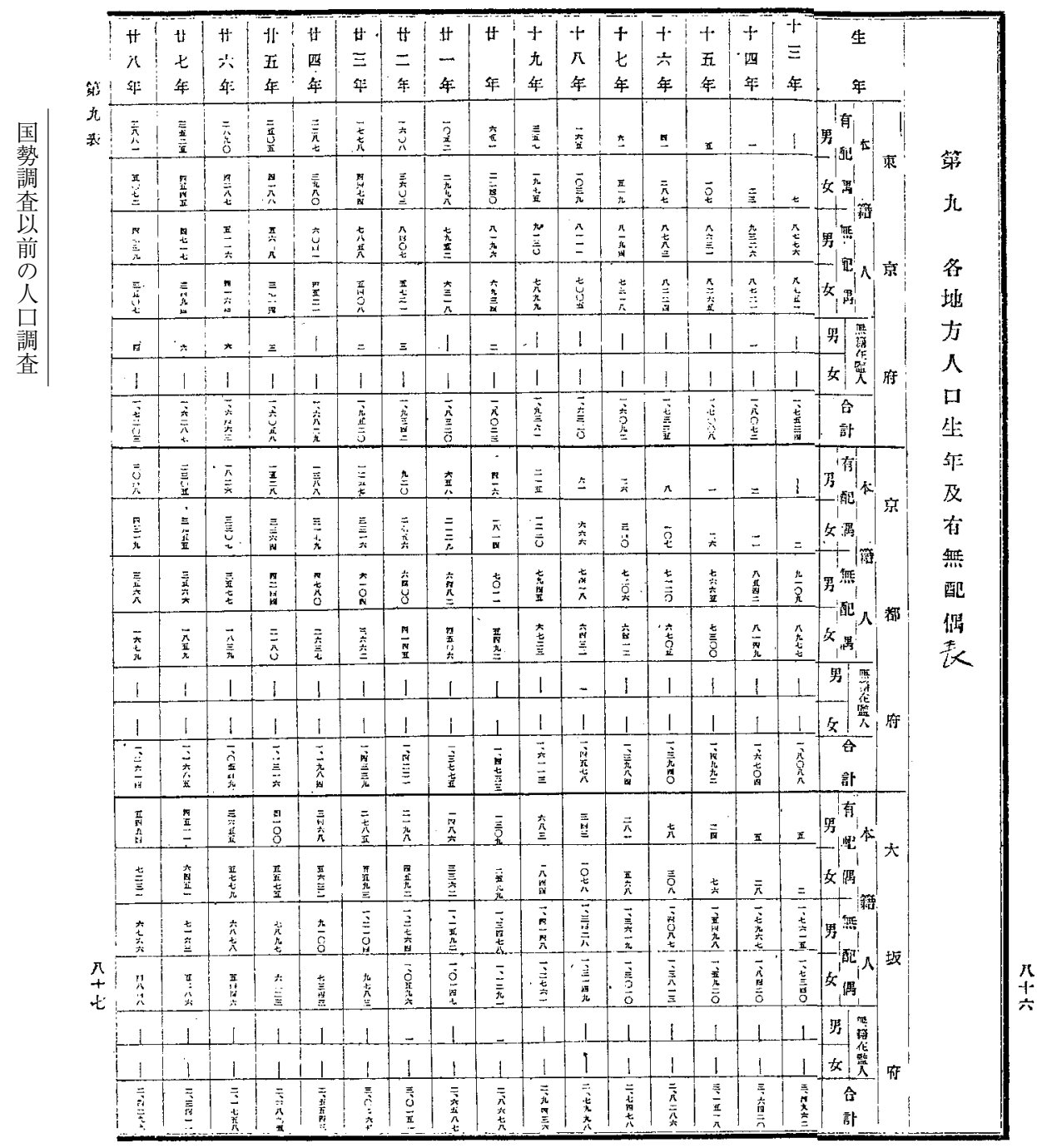

五 
図表 4 明治31年『日本帝国人口統計』

第一表 本町村别本籍人口現住人口及現传巨數

\begin{tabular}{|c|c|c|c|c|c|c|c|c|c|c|}
\hline \multirow[t]{2}{*}{ 拊粽北海道 } & \multicolumn{2}{|c|}{ 本 籍 } & $\square$ & \multicolumn{3}{|c|}{ 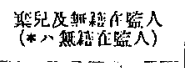 } & \multicolumn{3}{|c|}{ 現 佳 人 口 } & \multirow[t]{2}{*}{ 現任巨謨 } \\
\hline & 等 & 女 & 䛨 & 男 & 女 & 計 & 罗 & 女 & 計 & \\
\hline \multicolumn{11}{|l|}{ 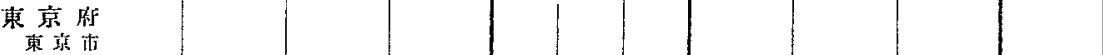 } \\
\hline 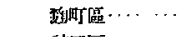 & 15,182 & 14,966 & 30,148 & 3 & i & 4 & 48,009 & 33,957 & 81,966 & 15,836 \\
\hline 神畞医 & $4: 3,089$ & $41,51.8$ & $8 t_{2} 607$ & 12 & 11 & 23 & 71,407 & 54,875 & 126,282 & $25,54 \pm$ \\
\hline 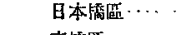 & 38,161 & 39,186 & $77,3 \div 7$ & 7 & 5 & 12 & 79,159 & 58,265 & 137,424 & 24,213 \\
\hline 京標隄. & 38,990 & 39,685 & 78675 & 15 & 8 & 23 & 75,824 & 62,869 & 138,793 & 27,224 \\
\hline 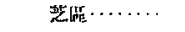 & 42,817 & 40,670 & 83,487 & 5 & 6 & 11 & 71,194 & $57,47 \mathrm{I}$ & 128,665 & $2 \notin, 739$ \\
\hline 躁初區. & 16,436 & 15,576 & 32,012 & 1 & l. & 2 & 30,825 & 23,714 & 54,539 & 12,767 \\
\hline 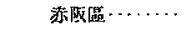 & 11,776 & 11,652 & 23,428 & 4 & 1 & 5 & 26,998 & $21), 913$ & 47,911 & 11,780 \\
\hline 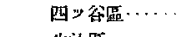 & 13,100 & $12,80 t$ & 25,904 & 2 & 2 & 4 & 23,738 & 19,689 & 43,427 & 10,656 \\
\hline 牛迲區 $\ldots$ & 19,877 & $19, \pm 31$ & 39,308 & $* \begin{array}{r}2 \\
11\end{array}$ & $\begin{array}{l}2 \\
1\end{array}$ & $\begin{array}{r}3 \\
12\end{array}$ & 29,523 & 24,816 & 54,329 & 11,688 \\
\hline 小矿川㡠. & 19,176 & 18,580 & 37,756 & 3 & -1 & 3 & 29,547 & 26,490 & 56,037 & 12,721 \\
\hline 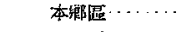 & 24,646 & 24,272 & 48,918 & 8 & 9 & 17 & 46,936 & $37,28 \pm$ & 84,220 & 19,515 \\
\hline 下谷䖪 & 36,461 & 35,732 & 72,193 & 14 & 6 & 20 & 60,398 & 51,797 & 112,195 & 21,705 \\
\hline 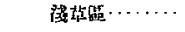 & 60,746 & 62,793 & 123,530 & $2 \mathrm{I}$ & 11 & 32 & 60,817 & 70,138 & 139,955 & 33,338 \\
\hline 本所橾…….... & 42,103 & 39,639 & 83,832 & 7 & 10 & 17 & 73,223 & 59,028 & 132,251 & 36,197 \\
\hline 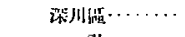 & $30.21: 1$ & 29.718 & 59,978 & $\frac{2}{25}$ & 2 & 1 & 54,7112 & 47,425 & 102,127 & 28,595 \\
\hline 部 $\cdots$ & 452,910 & 446,222 & 899,132 & * 110 & $\begin{array}{r}75 \\
1\end{array}$ & $\begin{array}{r}180 \\
12\end{array}$ & 791,400 & 648,721 & $1,440,121$ & 316,527 \\
\hline 品组町。 & 6,385 & 6.865 & 13,250 & 1 & - & 1 & 10,713 & 9,283 & 19,996 & 3,593 \\
\hline 大森朾. & 5,606 & 5,400 & 11,006 & - & 一 & -1 & 5,635 & 5,456 & 11,091 & 1,820 \\
\hline 大来赫… & 2,978 & 2,887 & 5,865 & 2 & 1 & 3 & 3,116 & 2,943 & 6,059 & 1,137 \\
\hline 入莉代柿. & 1,451 & 1,439 & 2,890 & - & - & 一 & 1,429 & 1,397 & 2,826 & 559 \\
\hline 簿田膊. & 1,150 & 1,215 & 2,365 & - & - & -1 & 1,066 & 1,095 & 2,161 & 341 \\
\hline 翉田湖. & 5,126 & 4,977 & 10,105 & - & - & - & 5,069 & 4,924 & 0,993 & 1,663 \\
\hline 六银何。 & 1,440 & 1,438 & 2,878 & - & - & - & 1,519 & 1,451 & 2,970 & 607 \\
\hline 矢口村 . & 1,527 & 1,552 & 3,079 & - & - & - & 1,463 & 1,612 & 2,975 & 471 \\
\hline 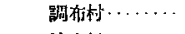 & 1,468 & 1,438 & 2,906 & - & - & - & 1,409 & 1,379 & 2,788 & $4: 39$ \\
\hline 治上标…...... & 2,272 & 2,257 & 4,529 & - & - & - & 2,157 & 2,162 & 4,319 & 668 \\
\hline 馬込村 .......... & 1,201 & 1,171 & 2,372 & - & - & - & 1,115 & 1,099 & 2,214 & 360 \\
\hline 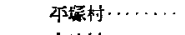 & 1,730 & 1,608 & 3,338 & $一$ & - & -1 & 1,713 & 1,584 & 3,297 & 492 \\
\hline 大猗村 ......... & 1,641 & 1,476 & 3,117 & $-\infty$ & - & -1 & 1,460 & 1,352 & 2,812 & 621 \\
\hline 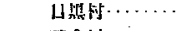 & 2,0933 & 2,003 & 4,096 & - & $\rightarrow$ & - & $2,13 \cdot 4$ & 1,081 & 4,115 & 978 \\
\hline 碑金捄…….... & 1,680 & 1,684 & 3,364 & 一 & - & - & 1,627 & 1,588 & 3,215 & 520 \\
\hline 㽛军驸……. & 1,604 & 1,600 & 3,204 & - & 一 & - & 2,557 & $1,5 \pm 1$ & 4,098 & 469 \\
\hline 世眐方谷村 & 2,848 & 2,700 & 5,638 & 一 & - & -1 & 4,809 & 2,951 & 7,760 & 818 \\
\hline 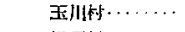 & 2,980 & 3,000 & 5,980 & - & - & - & 3,049 & 2,962 & 6,011 & 840 \\
\hline 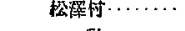 & 884 & 865 & 1,749 & $=$ & - & - & 821 & 801 & 1,622 & 226 \\
\hline 計 $\cdots$ & 46,064 & 45,667 & 91,731 & 3 & 1 & 4 & 52,861 & 47,461 & 100,322 & 16,622 \\
\hline
\end{tabular}


図表 5 明治32年『日本帝国人口動態統計』

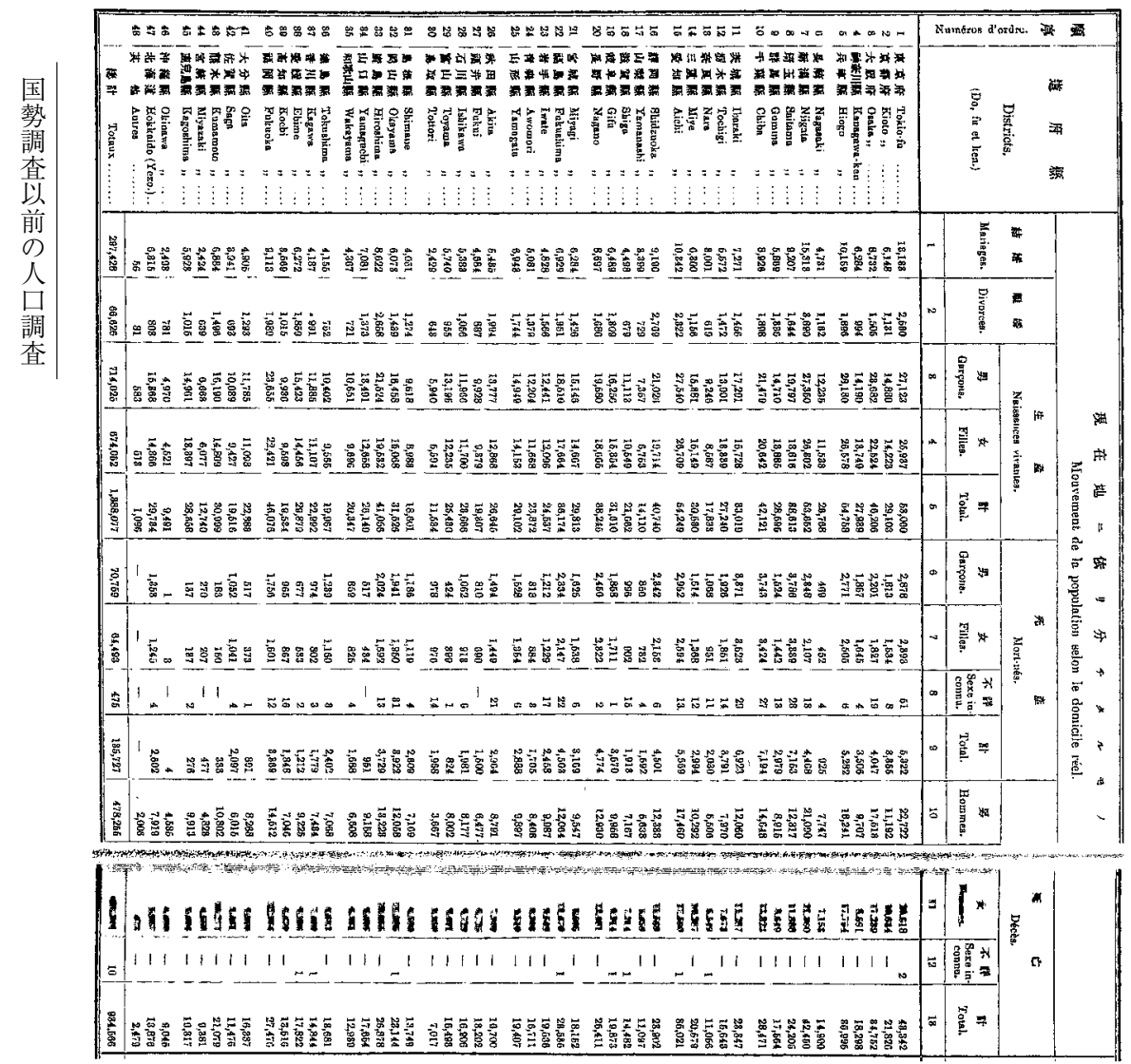


図表 6 明治17年『都府名邑戸口表』

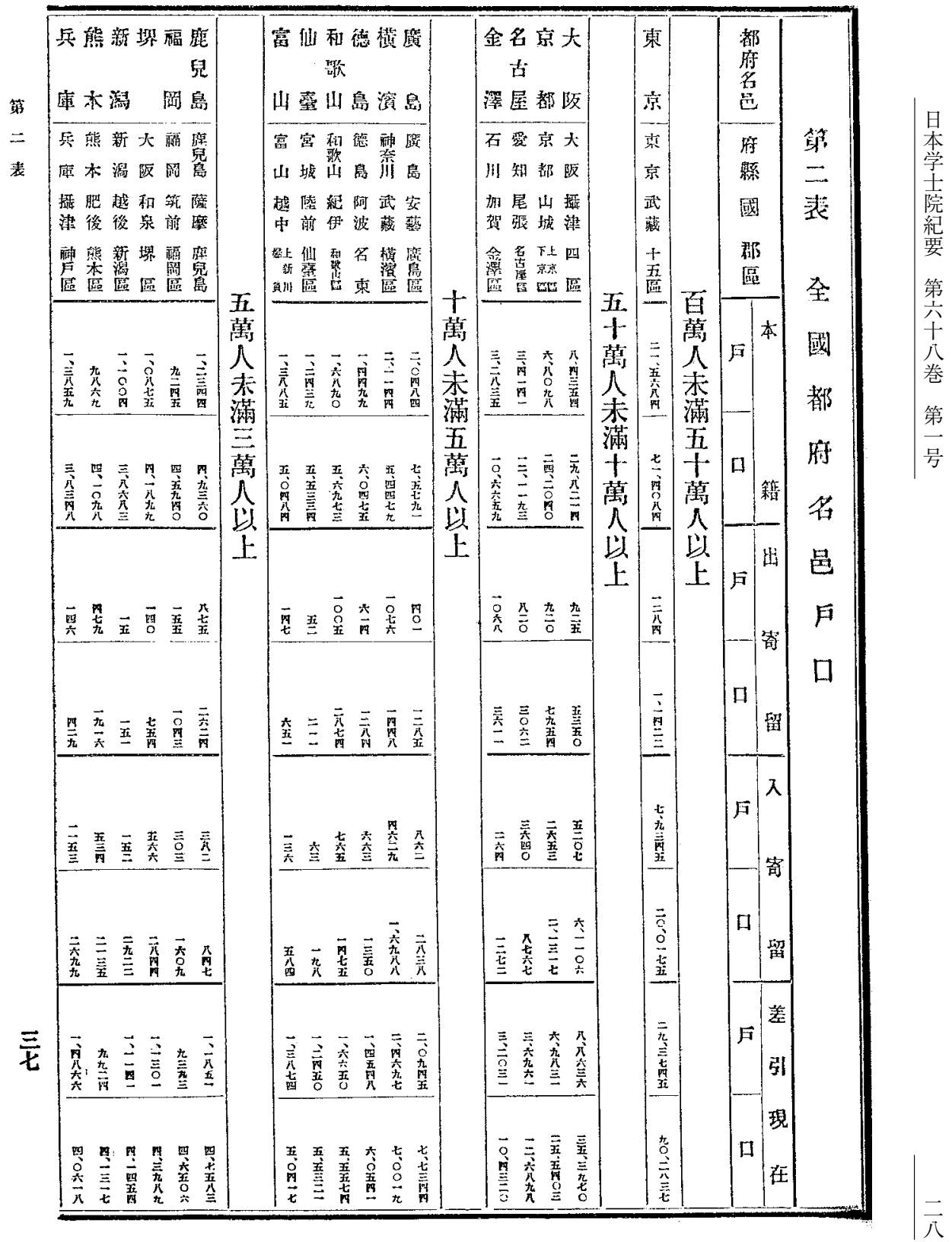




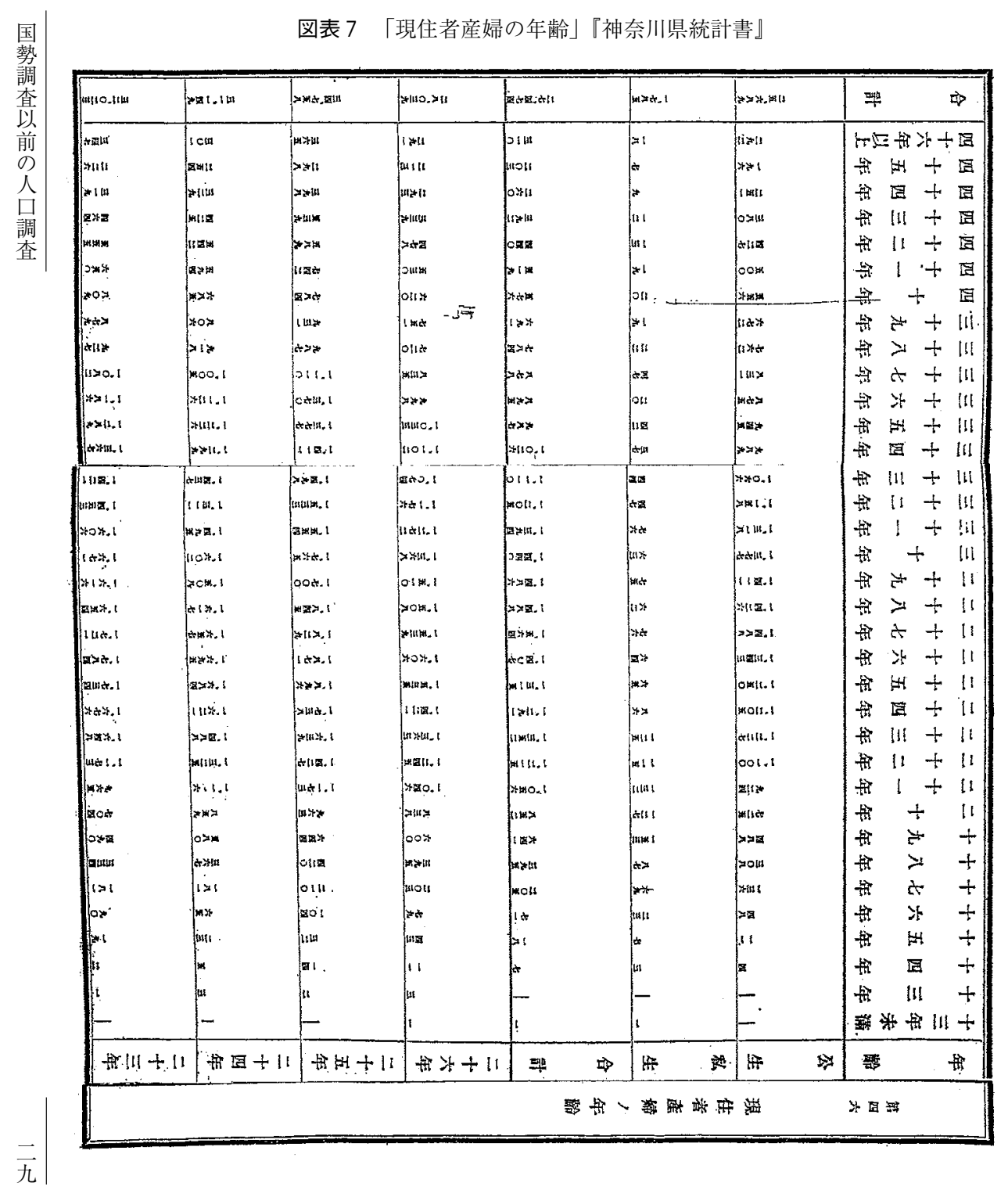


図表 8 神奈川県・横浜市の TFR

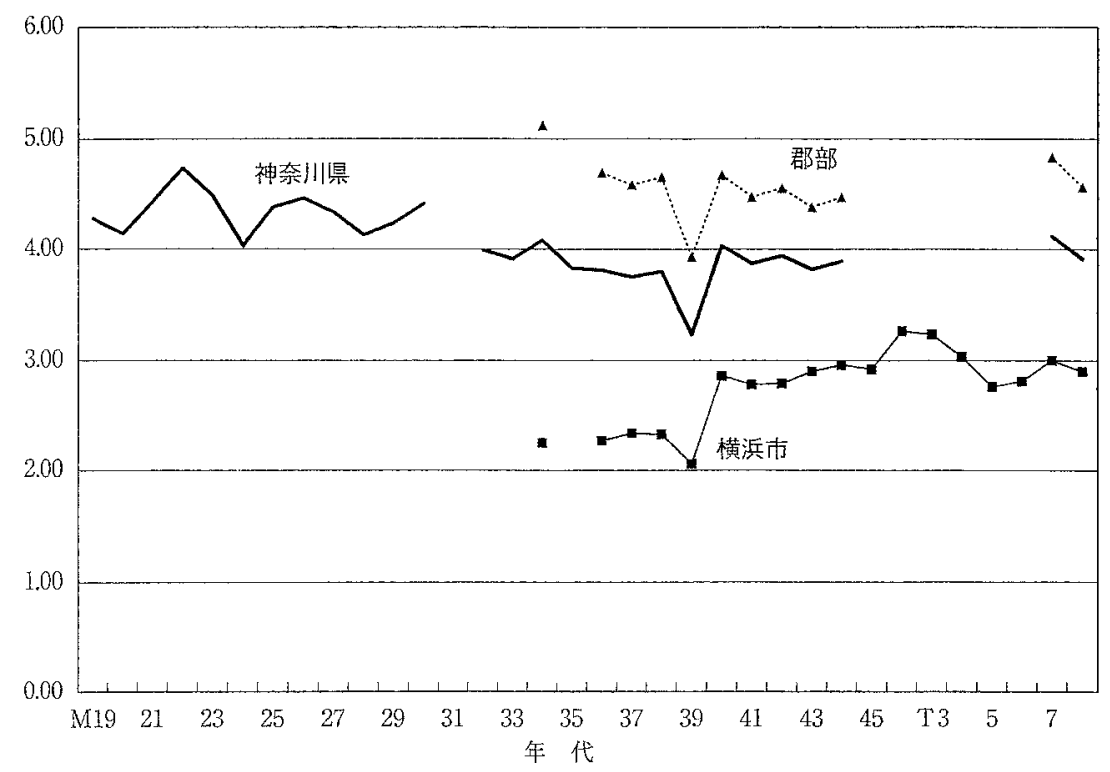

図表 9 大正 5 年・ 14 年・昭和 5 年における 16 道府県合計出生率

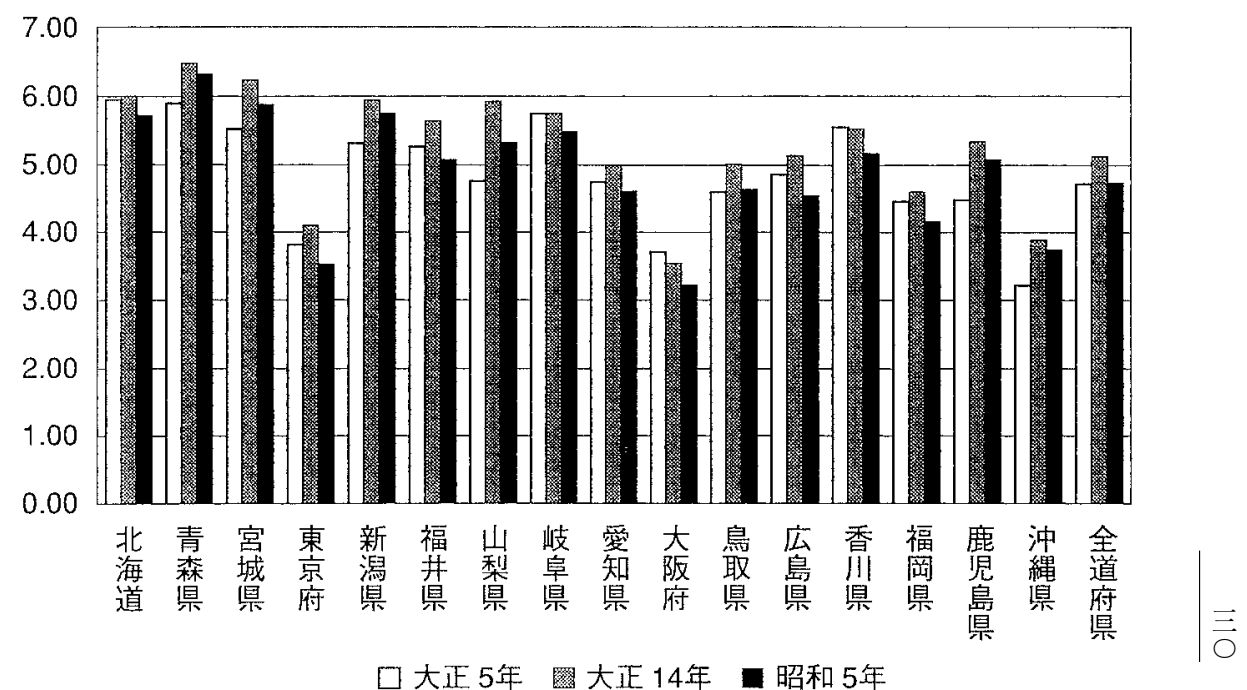


図表10 妻の生まれ年別出生児数割合および平均出生児数 1890－1925年生まれ

\begin{tabular}{|c|c|c|c|c|c|c|c|}
\hline \multirow{2}{*}{ 妻の生まれ年 } & \multirow{2}{*}{ 調査年次 } & \multicolumn{5}{|c|}{ 出生児数割合 (\%) } & \multirow{2}{*}{$\begin{array}{l}\text { 平均出生 } \\
\text { 児数 (人) }\end{array}$} \\
\hline & & 無子 & 1 人 & 2 人 & 3 人 & 4 人以上 & \\
\hline $1890 \sim 1895$ & 1950 & 11.3 & 8.3 & 7.8 & 8.9 & 63.8 & 4.8 \\
\hline $1895 \sim 1900$ & 1950 & 9.9 & 8.7 & 8.0 & 9.3 & 64.0 & 4.8 \\
\hline $1900 \sim 1905$ & 1950 & 9.0 & 8.6 & 8.4 & 9.7 & 64.3 & 4.8 \\
\hline $1910 \sim 1915$ & 1960 & 7.6 & 9.8 & 11.2 & 14.8 & 56.6 & 3.93 \\
\hline $1920 \sim 1925$ & 1970 & 7.9 & 11.3 & 24.1 & 28.2 & 28.5 & 2.77 \\
\hline
\end{tabular}

出典：『2013 人口の動向 日本と世界一人口統計資料集一』p. 70、2013年 
図表11 人口趨勢 : 1872-1919

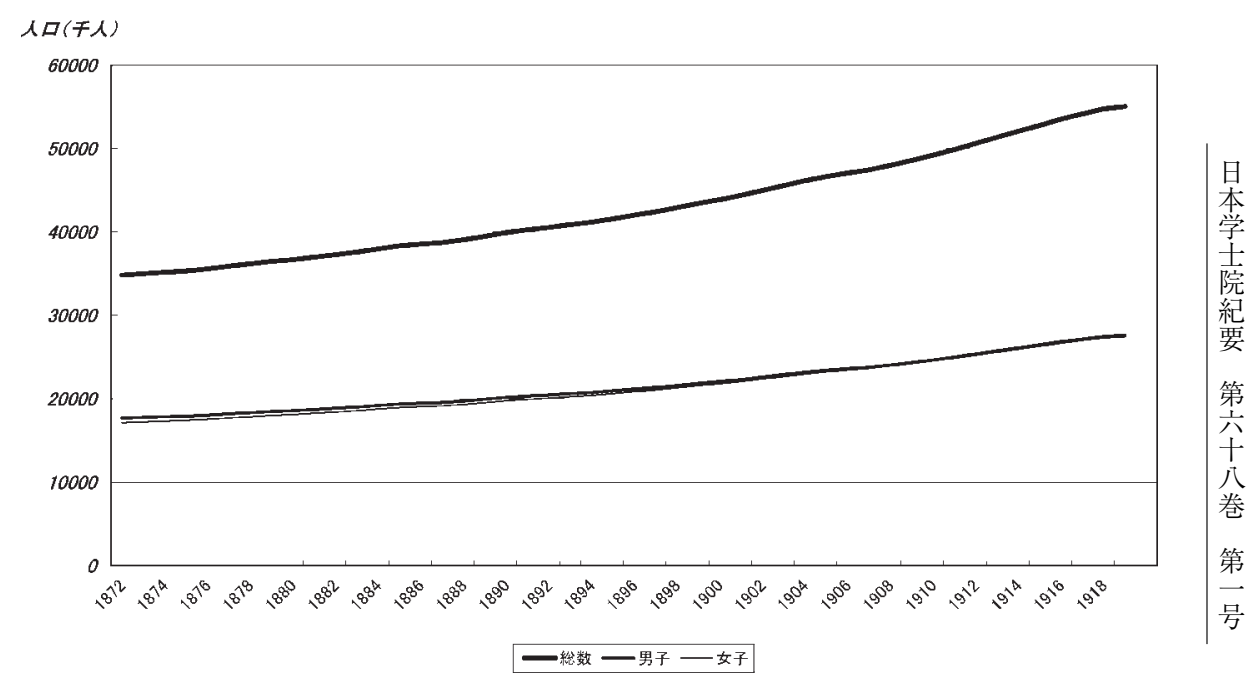

図表12 出生率と死亡率（\%)

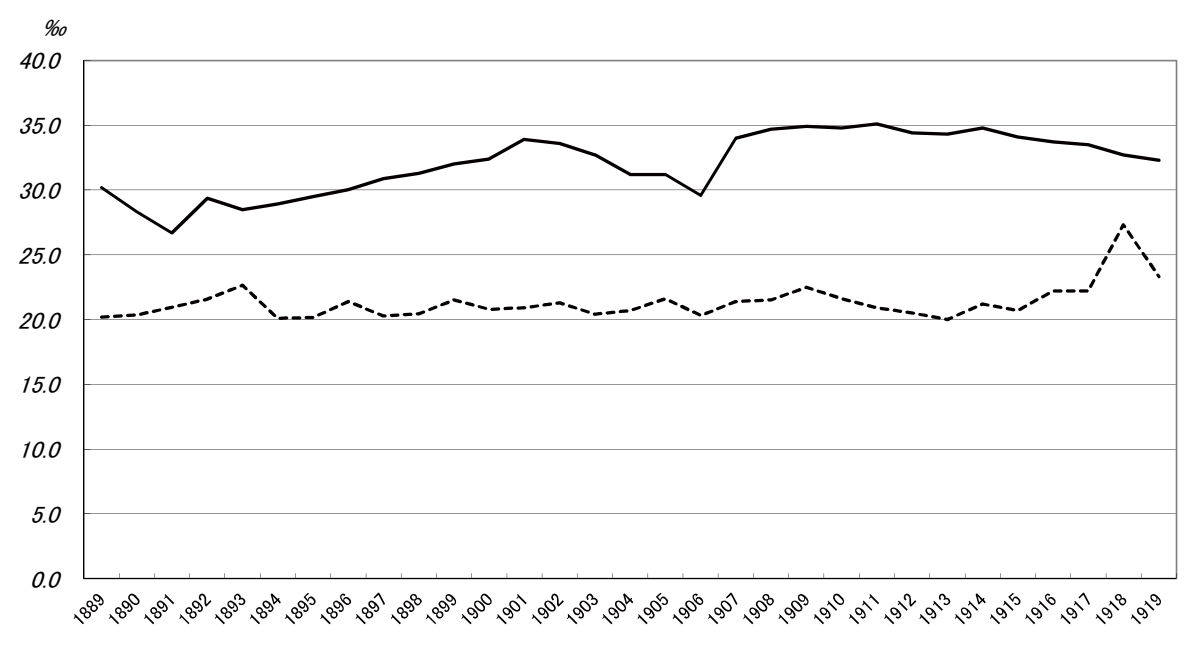

一出生率 ---・死亡率 


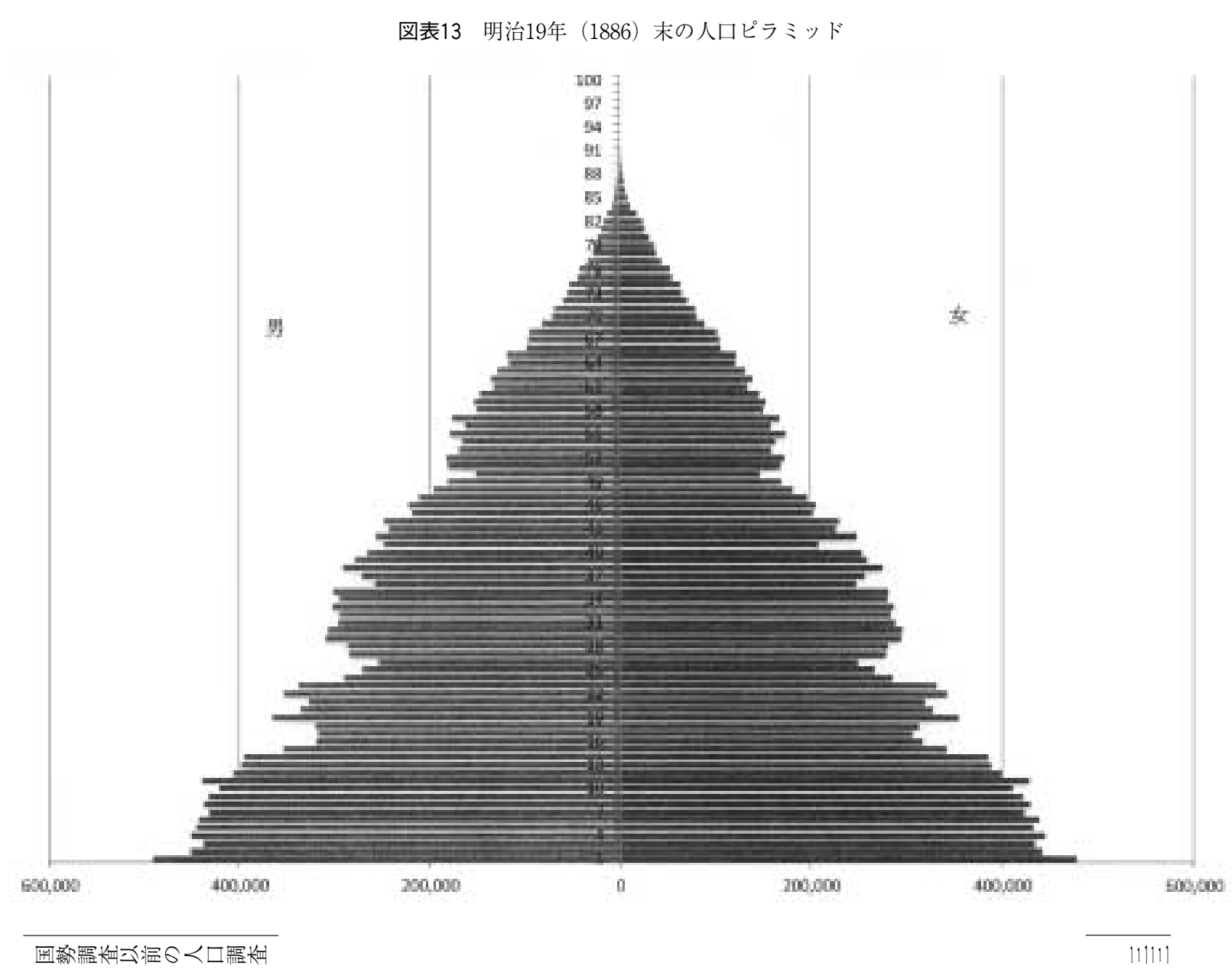


図表14 有配偶率が40\%を超える年齢

明治19年（1886）

\begin{tabular}{|c|c|c|c|c|}
\hline 府 & 県 & 名 & 男 子 & 女 子 \\
\hline 全 & & 国 & 26 & 22 \\
\hline 北 & 海 & 道 & 27 & 23 \\
\hline 青 & 森 & 県 & 23 & 19 \\
\hline 岩 & 手 & 県 & 22 & 18 \\
\hline 宮 & 城 & 県 & 23 & 20 \\
\hline 秋 & 田 & 県 & 22 & 18 \\
\hline 山 & 形 & 県 & 24 & 20 \\
\hline 福 & 島 & 県 & 22 & 20 \\
\hline 茨 & 城 & 県 & 23 & 21 \\
\hline 栃 & 木 & 県 & 23 & 21 \\
\hline 群 & 馬 & 県 & 23 & 20 \\
\hline 埼 & 玉 & 県 & 23 & 22 \\
\hline 千 & 葉 & 県 & 23 & 20 \\
\hline 東 & 京 & 府 & 27 & 23 \\
\hline 神 & 奈 川 & 県 & 26 & 23 \\
\hline 新 & 潟 & 県 & 25 & 21 \\
\hline 富 & 山 & 県 & 26 & 20 \\
\hline 石 & 川 & 県 & 28 & 22 \\
\hline 福 & 井 & 県 & 28 & 22 \\
\hline 山 & 梨 & 県 & 25 & 22 \\
\hline 長 & 野 & 県 & 25 & 21 \\
\hline 岐 & 阜 & 県 & 28 & 22 \\
\hline 静 & 岡 & 県 & 24 & 20 \\
\hline 愛 & 知 & 県 & 27 & 22 \\
\hline 三 & 重 & 県 & 26 & 22 \\
\hline 滋 & 賀 & 県 & 28 & 23 \\
\hline 京 & 都 & 府 & 28 & 23 \\
\hline 大 & 阪 & 府 & 28 & 24 \\
\hline 兵 & 庫 & 県 & 28 & 23 \\
\hline 奈 & 良 & 県 & 28 & 24 \\
\hline 和 & 歌 山 & 県 & 28 & 24 \\
\hline 鳥 & 取 & 県 & 26 & 22 \\
\hline 島 & 根 & 県 & 27 & 22 \\
\hline 岡 & 山 & 県 & 27 & 22 \\
\hline 広 & 島 & 県 & 26 & 22 \\
\hline 山 & 口 & 県 & 28 & 23 \\
\hline 德 & 島 & 県 & 26 & 23 \\
\hline 香 & 川 & 県 & 28 & 23 \\
\hline 愛 & 媛 & 県 & 28 & 23 \\
\hline 高 & 知 & 県 & 26 & 20 \\
\hline 福 & 岡 & 県 & 27 & 23 \\
\hline 佐 & 賀 & 県 & 28 & 23 \\
\hline 長 & 崎 & 県 & 27 & 23 \\
\hline 熊 & 本 & 県 & 26 & 23 \\
\hline 大 & 分 & 県 & 26 & 22 \\
\hline 宮 & 崎 & 県 & 26 & 22 \\
\hline 鹿 & 児 島 & 県 & 27 & 24 \\
\hline 沖 & 縄 & 県 & 25 & 23 \\
\hline
\end{tabular}


図表15 大都市の現住人口と本籍人口

\begin{tabular}{|c|c|c|c|c|c|c|c|c|c|c|c|c|}
\hline \multicolumn{5}{|c|}{ 明 治 17 年 } & \multicolumn{4}{|c|}{ 明 治 36 年 } & \multicolumn{4}{|c|}{ 大正 7 年 } \\
\hline 都 & 市 & 現住人口 & 本籍人口 & 現住/本籍 (\%) & 都 市 & 現住人口 & 本籍人口 & 現住/本籍 (\%) & 都 市 & 現住人口 & 本籍人口 & 現住/本籍 (\%) \\
\hline 函 & 館 & 38417 & 26908 & 142.8 & 佐世保市 & 68344 & 12251 & 557.9 & 佐世保市 & 123555 & 31261 & 395.2 \\
\hline 横 & 浜 & 70019 & 54479 & 128.5 & 門 司 市 & 38065 & 10801 & 352.4 & 八 幡 市 & 89472 & 24618 & 363.4 \\
\hline 東 & 京 & 902837 & 714084 & 126.4 & 久留米市 & 83273 & 26898 & 309.6 & 門 司 市 & 73377 & 25333 & 289.6 \\
\hline 大 & 阪 & 353970 & 298214 & 118.7 & 小 樽 区 & 79361 & 35525 & 223.4 & 室 蘭 区 & 58349 & 21676 & 269.2 \\
\hline 長 & 崎 & 39016 & 33073 & 118.0 & 小 倉 市 & 36825 & 16996 & 216.7 & 市 & 154687 & 62086 & 249.1 \\
\hline 新 & 潟 & 41454 & 38683 & 107.2 & 長 崎 市 & 153293 & 72730 & 210.8 & 横須 賀 市 & 88742 & 37715 & 235.3 \\
\hline 岡 & 山 & 31789 & 30007 & 105.9 & 呉 & 66006 & 31436 & 210.0 & 大牟田市 & 72482 & 32483 & 223.1 \\
\hline 兵 & 庫 & 40618 & 38348 & 105.9 & 横 浜 市 & 326035 & 167747 & 194.4 & 神 戸 市 & 592726 & 286911 & 206.6 \\
\hline 京 & 都 & 255403 & 242040 & 105.5 & 岡 山 市 & 81025 & 44013 & 184.1 & 旭 川 区 & 69421 & 33623 & 206.5 \\
\hline 堺 & & 43989 & 41899 & 105.0 & 札 幌 区 & 55304 & 30154 & 183.4 & 大 阪 市 & 1641580 & 795995 & 206.2 \\
\hline 名 古 & 屋 & 126898 & 121193 & 104.7 & 四日市市 & 30140 & 16523 & 182.4 & 若松市 (福岡県) & 41411 & 20375 & 203.2 \\
\hline & 島 & 77344 & 75791 & 102.0 & 東 京 市 & 1818655 & 1008060 & 180.4 & 豊＼cjkstart橋＼cjkstart市 & 66839 & 34246 & 195.2 \\
\hline 福 & 岡 & 46506 & 45940 & 101.2 & 大 阪 市 & 995945 & 590898 & 168.5 & 長 崎 市 & 198147 & 106352 & 186.3 \\
\hline 熊 & 本 & 41317 & 41098 & 100.5 & 神 戸 市 & 285002 & 173828 & 164.0 & 浜 松 市 & 61029 & 33284 & 183.4 \\
\hline 徳 & 島 & 60541 & 60475 & 100.1 & 長 野 市 & 37202 & 22728 & 163.7 & 横 浜 市 & 447423 & 267704 & 167.1 \\
\hline 仙 & 台 & 55321 & 55334 & 100.0 & 大 津 市 & 39595 & 24606 & 160.9 & 市 & 54522 & 32683 & 166.8 \\
\hline 飫 & 肥 & 33850 & 33869 & 99.9 & 甲 府 市 & 44188 & 27930 & 158.2 & 八王子市 & 42661 & 25727 & 165.8 \\
\hline 富 & 山 & 50417 & 50484 & 99.9 & 名古屋市 & 288639 & 186761 & 154.5 & 四日市市 & 34427 & 21063 & 163.4 \\
\hline 秋 & 田 & 30602 & 30759 & 99.5 & 高 崎 市 & 35226 & 22864 & 154.1 & 東 京 市 & 2347442 & 1437490 & 163.3 \\
\hline 松 & 江 & 36164 & 36359 & 99.5 & & 36408 & 24340 & 149.6 & 岡 崎 市 & 39996 & 24783 & 161.4 \\
\hline 合 & 計 & 2376472 & 2069037 & 114.9 & 丸 亀 市 & 28456 & 19433 & 146.4 & 大 津 市 & 43550 & 27171 & 160.3 \\
\hline & & & & & 下 関 市 & 46285 & 31812 & 145.5 & 松 本 市 & 50356 & 31501 & 159.9 \\
\hline & & & & & 尾 道 市 & 30529 & 21154 & 144.3 & 水 戸 市 & 53030 & 33258 & 159.5 \\
\hline & & & & & 岐 阜 市 & 40168 & 28761 & 139.7 & 岡 山 市 & 96446 & 60831 & 158.5 \\
\hline & & & & & 前 橋 市 & 41714 & 30245 & 137.9 & 甲 府 市 & 58453 & 37354 & 156.5 \\
\hline & & & & & 京 都 市 & 380568 & 303509 & 125.4 & 合 計 & 6600123 & 3545523 & 186.2 \\
\hline & & & & & 合 計 & 5166251 & 2982003 & 173.2 & & & & \\
\hline
\end{tabular}


図表16 大都市における出生率と死亡率（1）

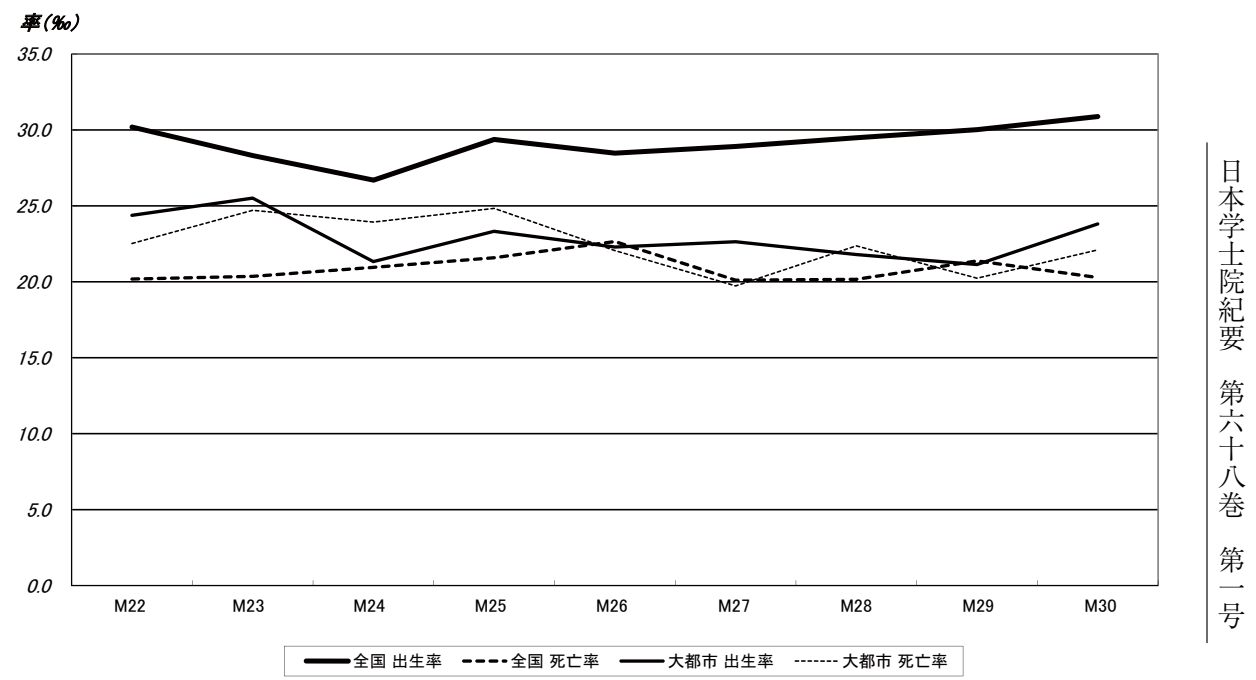

図表16 大都市における出生率と死亡率（2）

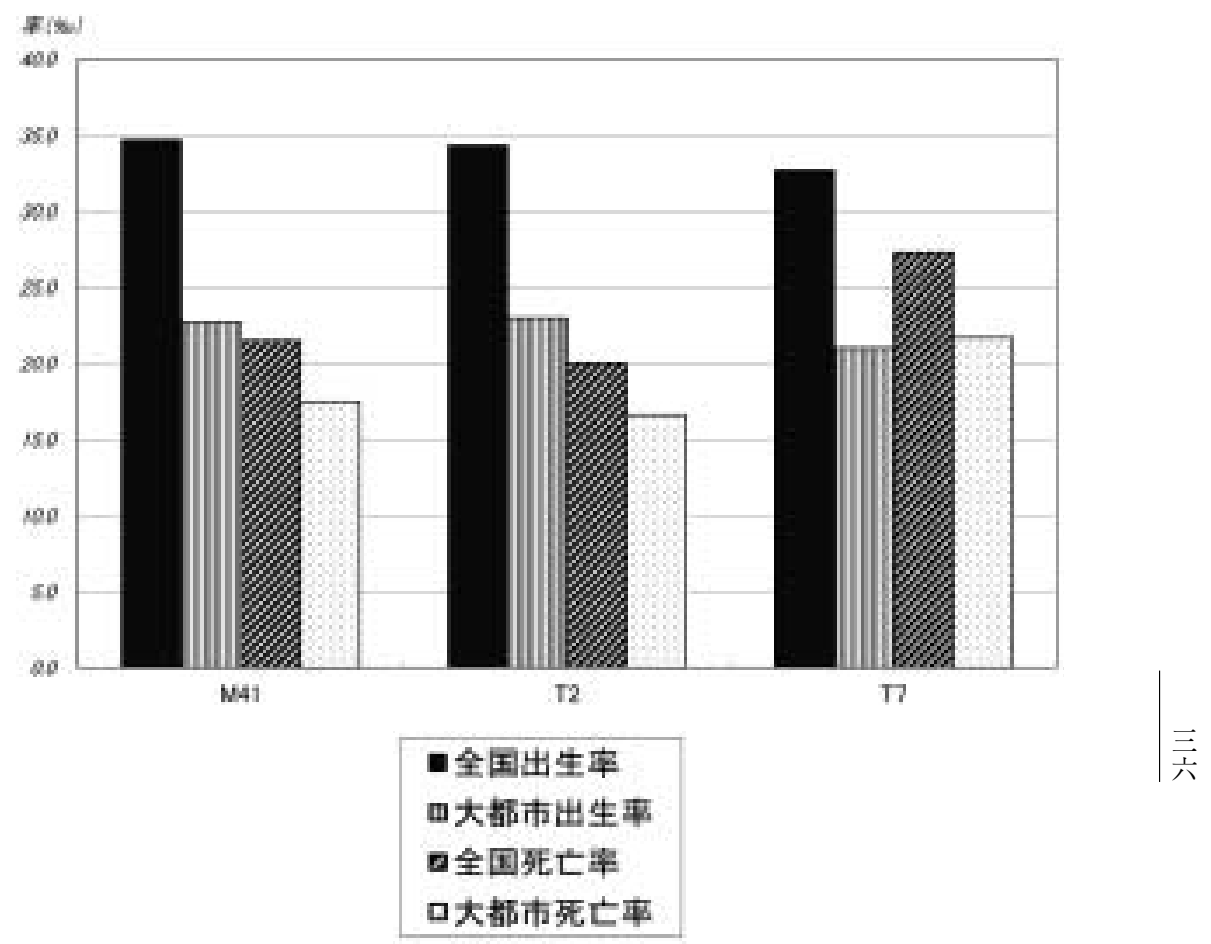


図表17 全死亡者中の結核による者の割合

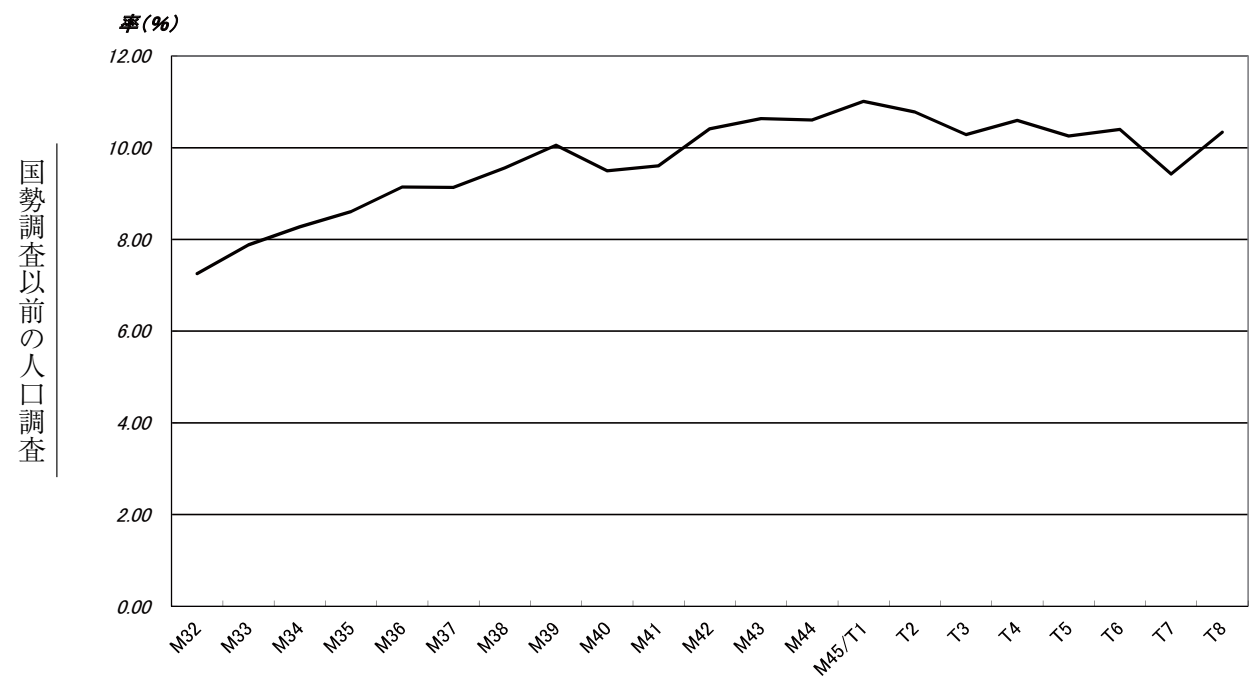

図表18 生命表による平均寿命

\begin{tabular}{|l|l|c|c|c|c|}
\cline { 3 - 6 } \multicolumn{2}{c|}{} & \multicolumn{2}{c|}{ 統計局作成 } & \multicolumn{2}{c|}{ 水島生命表 } \\
\hline \multicolumn{2}{|c|}{ 時 } & 男 子 & 女 子 & 男 子 & 女 子 \\
\hline 明治24-31 & 第 1 回 & 42.8 & 44.3 & 35.29 & 36.86 \\
\hline 明治32-36 & 第2 回 & 43.97 & 44.85 & 37.80 & 38.20 \\
\hline 明治42-大正 2 & 第3 回 & 44.25 & 44.73 & 40.22 & 40.82 \\
\hline 大正10-14 & 第4 回* & & & 42.06 & 43.20 \\
\hline
\end{tabular}

出典：『生命表研究』表 $1-2$ および表 $1-3$ より作成

$*$ 内閣統計局作成 
図表19 死産率（関東 5 県と全国）

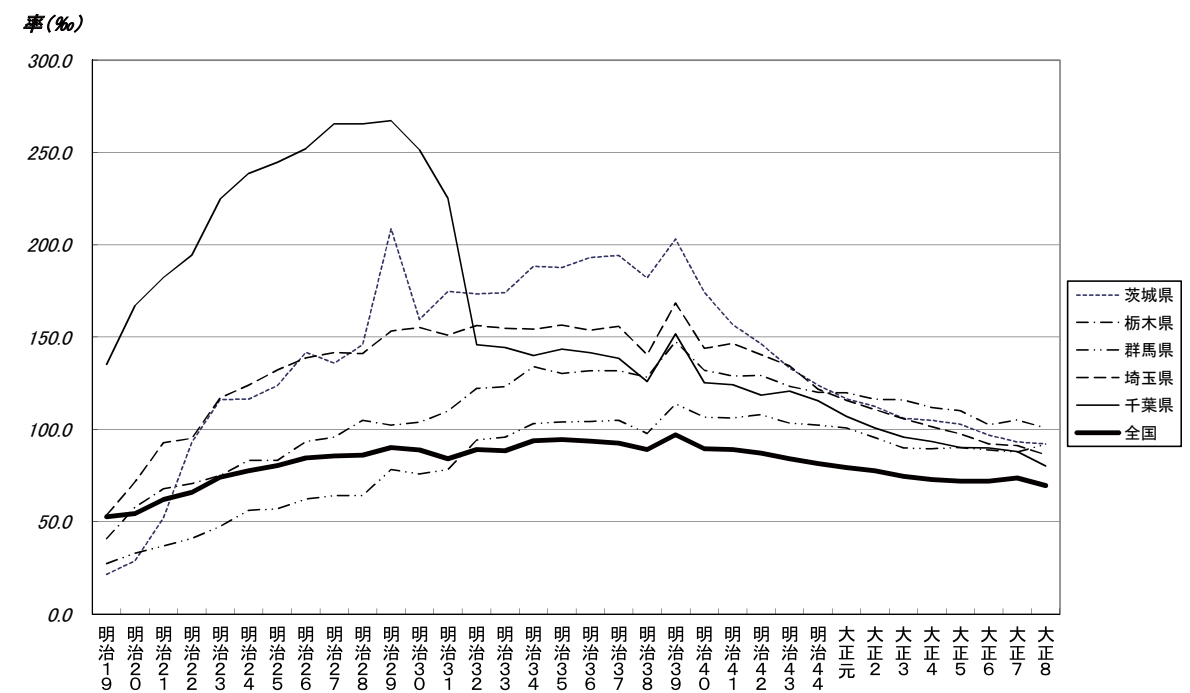

図表20 壮丁身長分布（神奈川県）

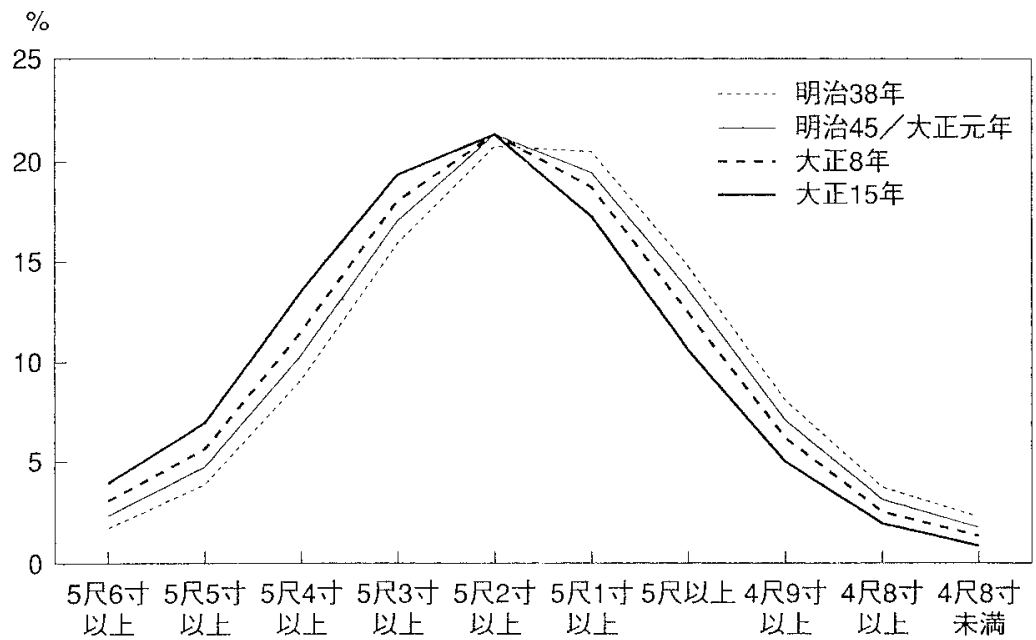


図表21 教育程度別人口割合

\section{大正 3 年における教育程度別人口割合（神奈川県）}
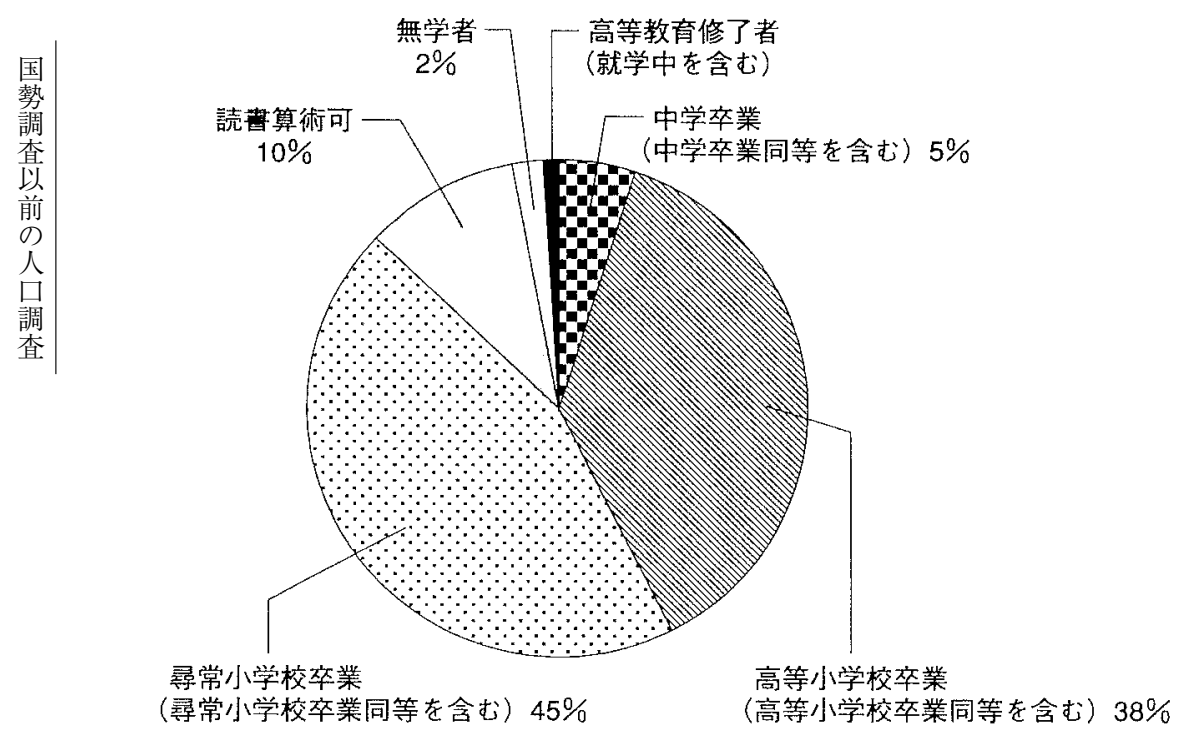

大正 15 年における教育程度別人口割合（神奈川県）

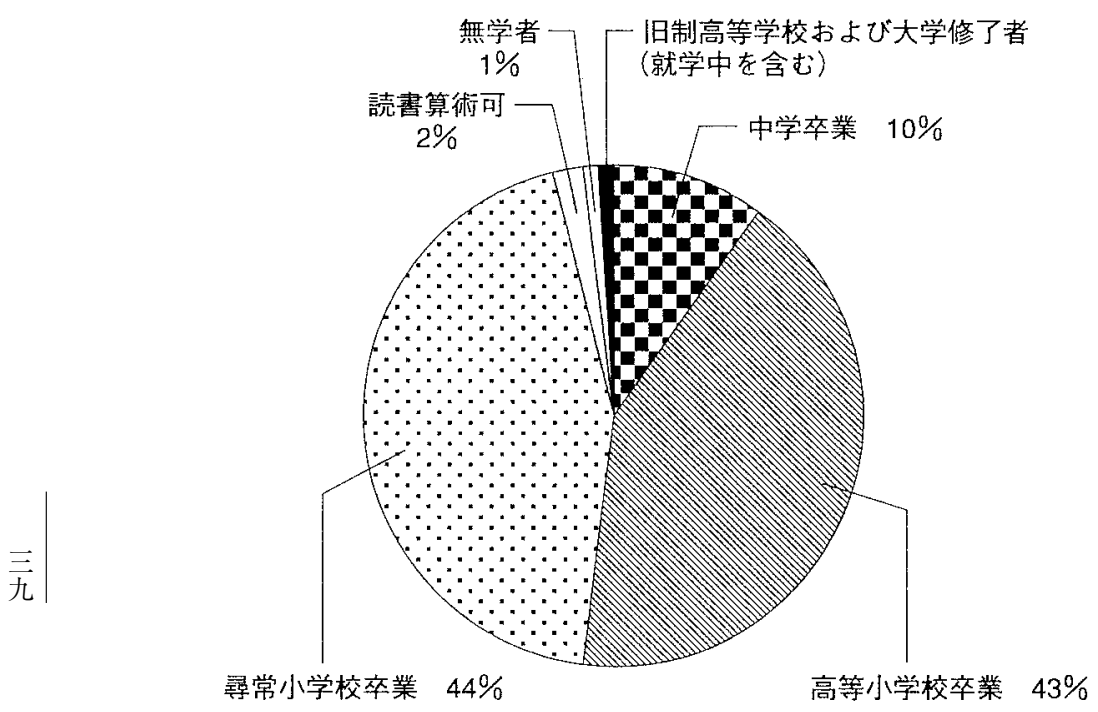


図表22 駿河國沼津政表（明治 2 年）

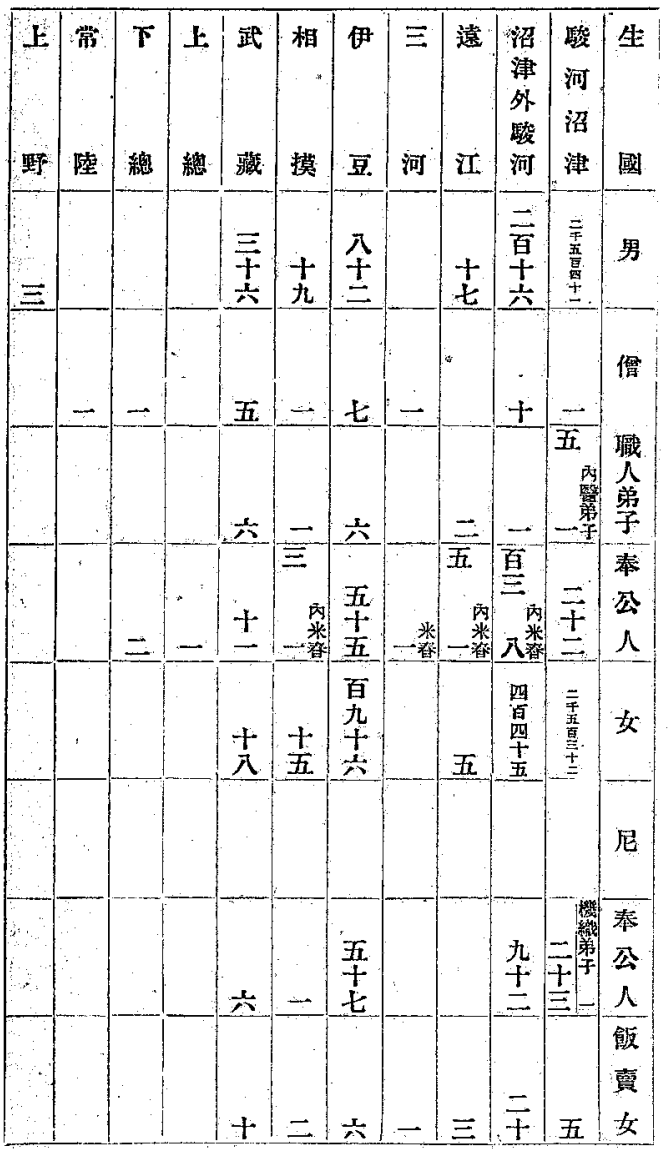

\begin{tabular}{|c|c|c|c|}
\hline \multicolumn{2}{|c|}{ 女 } & \multicolumn{2}{|c|}{ 男 } \\
\hline 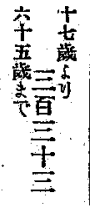 & 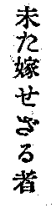 & 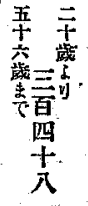 & 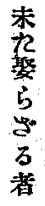 \\
\hline 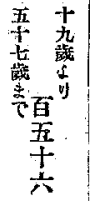 & $\begin{array}{l}\text { 滩 } \\
\text { “緣 } \\
\text { 毕 } \\
\text { L } \\
\text { 荐 }\end{array}$ & 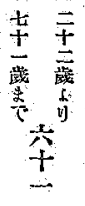 & $\begin{array}{l}\text { 踓 } \\
\text { 紸 } \\
\text { 叉 } \\
\text { し } \\
\text { 者 }\end{array}$ \\
\hline 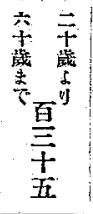 & $\begin{array}{l}\text { 再 } \\
\text { 線 } \\
せ \\
\text { せ } \\
\text { 老 }\end{array}$ & 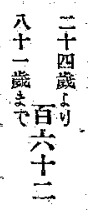 & $\begin{array}{l}\text { 再 } \\
\text { 緣 } \\
\text { せ } \\
\text { 己 } \\
\text { 者 }\end{array}$ \\
\hline 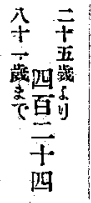 & $\begin{array}{l}\text { 夫 } \\
\text { 死 } \\
せ \\
\llcorner \\
\text { 老 }\end{array}$ & 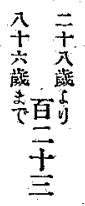 & $\begin{array}{l}\text { 车 } \\
\text { 死 } \\
\text { せ } \\
\text { L } \\
\text { 者 }\end{array}$ \\
\hline $\begin{array}{l}7 \\
\text { 四 } \\
+1 \\
\text { 入 }\end{array}$ & 小 & 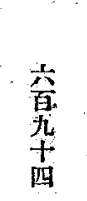 & 小 \\
\hline
\end{tabular}


図表23 明治 12 年『甲斐国現在人別調』

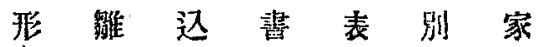

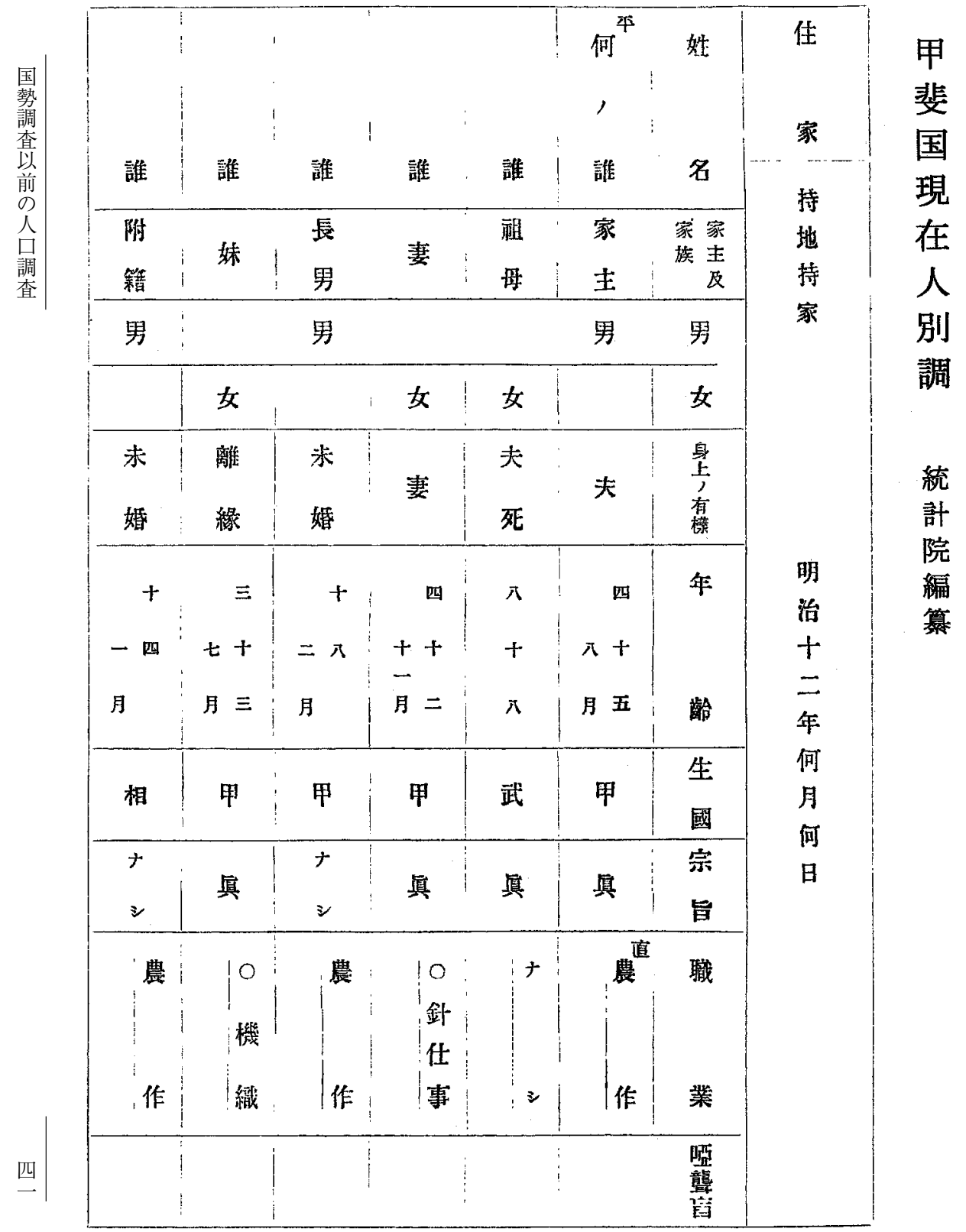


of partner (not marital status). Through these statistics, we can draw an age pyramid for Japan and gauge the age composition both totally and locally. If not accurate, these statistics can be used to estimate the mean marriage age by prefecture. The results for the year 1886 were not that different from the Tokugawa period when industrialization and urbanization had not yet advanced. This was a very valuable gift bequeathed by early Meiji statistics.

Of local statistics, Kanagawa Prefecture achieved a magnificent feat in its compilation of a demographic index. In 1886 and after, the Statistics Department of the prefecture kept a table titled "age of childbearing genju females," the purpose of which is a mystery.

However, by closely observing the table, we can learn from it the fertility rate, as it records how many births women had at each age. This provides a basis for calculating the TFR! After 1903, the Yokohama City Statistics Office began keeping the same table, allowing us to compare the TFR of an urban and rural area (Kanagawa Prefecture). Nevertheless, we should reserve judgment on the final figures as we do not have the real population statistics of Kanagawa Prefecture or Yokohama City. We are left wondering why and by whom these tables were compiled at such an early time as 1886 .

Thus, we find several valuable statistics in almost forgotten historical sources before the 1920 census. But in utilizing them, we must do so critically. 
population, but in reality the genjū population was always more than the honseki population due to double counting in urban areas.

So then, are all population statistics before the 1920 census meaningless? The author does not think so as several statistical sources can be found that are worth considering. First, Kouji Sugi, who worked at the Dutch Books Investigation Office under the Tokugawa Government, knew about modern census taking used in Europe, and thought about applying it in Japan. After the Tokugawa Government collapsed in 1868, the last shogun became a local lord in Shizuoka. Sugi followed him there and did a test census in the towns of Numazu and Hara. Looking at the results, his survey yielded the same findings as others in modern times, with population by marital status, occupation, age, and so on. This was an extraordinary achievement given the fact that the period still smelt of gun smoke from fighting accompanying the Meiji Restoration.

The Meiji Government recognized Sugi's ability in compiling statistics and called him to Tokyo to ask him to conduct a national population survey based on family registers. Declining that assignment because he didn't believe the outcome would be accurate, Sugi returned to Shizuoka. A few years later, the government appointed him as head of its office for compiling general yearly statistics. Though he took the position, Sugi's love for census taking did not wane. He urged the government to conduct a test survey, which was finally executed in Yamanashi Prefecture in December 1879. Though not national, this was Japan's first modern census.

Sugi's next contribution was the establishment of the Statistic School (Kyoritsu Tokei Gakko) in 1884, from which several students with knowledge and ability in modern statistics exited and flourished. Most mentionable was a census taken graduates of his school in Taiwan in 1905. It placed Sugi 15 years ahead of homeland Japan in census taking.

Although the figures were for the honseki population, all of Japan's prefectural populations were first listed in 1886 . They included age, sex, and presence/absence 


\title{
Population Surveys before the First Census in 1920
}

\begin{abstract}
Akira HAYAMI, M. J. A.
The Meiji Government set out to calculate the population of Japan using family registers (jinshin-koseki) compiled in 1872. This, despite a statistician named Kouji Sugi having pointed out that compiling family registers was different from surveying populations. The most difficult problem was how to treat the moving population in other than legally recognized cases such as marriage, adoption, and permanent migration. On the family register, the Government introduced a concept of temporary staying and temporary going $(k i r y \bar{u})$. Under it, those who left their honseki (registered place) for more than 90 days were classified de-kiry $\bar{u}$, while those who entered another administrative unit were treated as iri-kiry $\bar{u}$. In every office, de-kiry $\bar{u}$ book and iri-kiry $\bar{u}$ book were kept instead of a register. When this system started, there may have been few problems with it ; but in the 1890's when industrialization and urbanization spread within Japan, many people began to come and go mainly between rural and urban areas. This poses several difficulties in using the system. For example, a person who came to work in Tokyo and settled there, might move from that first place to another place within the city, thus becoming registered twice in Tokyo. Such double or triple counting became much more prevalent when urbanization took hold.
\end{abstract}

The population of each administrative unit was called the residential (honsekide-kiry $\bar{u}+i r i-k i r y \bar{u})$ population, or genjū population, in both legally and not legally authorized cases. This procedure, however, was processed on paper, not by interview. This was the main weakness of the system when applied as a population survey, as it placed an unconceivable number of aging persons on the registers and indicated a larger population in urban area than existed due to double registering of the iri-kiry $\bar{u}$ population. In some cities, tallying of the kiry $\bar{u}$ population was practiced, but only for individuals. Thus, all population statistics before the 1920 census were inaccurate. When taking the populations of all residential units together, in theory the genjū population should balance with the honseki 